\title{
Tamara Prior
}

\section{Hereditariedade, progresso e decadência no pensamento médico-eugenista de Renato Kehl}

\author{
Dissertação apresentada à Faculdade de \\ Medicina da Universidade de São Paulo \\ para a obtenção do título de Mestre em \\ Ciências
}

Programa de Medicina Preventiva Orientador: Prof. Dr. André Mota

\section{São Paulo}




\section{Tamara Prior}

\section{Hereditariedade, progresso e decadência no pensamento médico-eugenista de Renato Kehl}

Dissertação apresentada à Faculdade de Medicina da Universidade de São Paulo para a obtenção do título de Mestre em Ciências

Programa de Medicina Preventiva

Orientador: Prof. Dr. André Mota

\section{São Paulo}

2015 


\title{
Dados Internacionais de Catalogação na Publicação (CIP)
}

\author{
Preparada pela Biblioteca da
}

Faculdade de Medicina da Universidade de São Paulo

Creprodução autorizada pelo autor

Prior, Tamara

Hereditariedade, progresso e decadência no pensamento médico-eugenista de Renato Kehl / Tamara Prior. -- São Paulo, 2015.

Dissertação(mestrado)--Faculdade de Medicina da Universidade de São Paulo. Programa de Medicina Preventiva.

Orientador: André Mota.

Descritores: 1.Saúde pública/história 2.História da Medicina 3.Eugenia (ciência) 4.Hereditariedade 5.Bioética 6.Filosofia médica 7.Brasil

USP/FM/DBD-519/15 


\section{AGRADECIMENTOS}

Aos meus pais Giuseppe e Edeméia, apoiadores incondicionais e responsáveis por qualquer mérito deste trabalho;

Ao meu orientador André Mota por ensinar, acima de tudo, o inominável;

Aos professores Francisco Queiroz, Marcia Couto e Ricardo Teixeira pelos ensinamentos passados durante a banca de qualificação, os quais elevaram os resultados desta pesquisa;

À Fapesp pelo apoio. 


\section{DEDICATÓRIA}

Ao Sérgio Batista Alves, brilhante professor da Esalq-USP. Por sorte minha, também meu querido padrinho que, ansioso pelo resultado deste trabalho, não pode esperar. 


\section{SUMÁRIO}

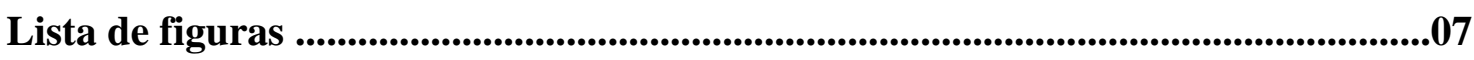

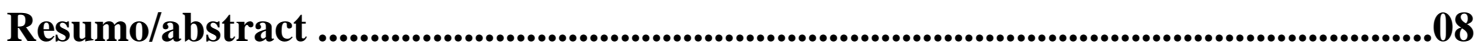

Introdução: Dimensões do passado remoto .............................................................. 09

Capítulo 1: A eugenia como síntese ............................................................................ 19

1.1 Francis Galton: a vida sob os desígnios da hereditariedade ................................ 19

1.2 Eugenia: uma breve palavra para nomear a ciência do melhoramento da espécie .. 26

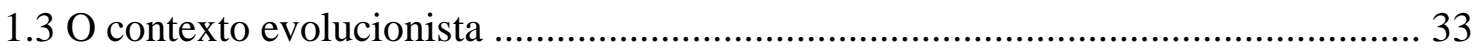

1.4 Criação de redes contra a "decadência biológica": as sociedades eugenistas pelo mundo

Capítulo 2: Olhares: aspectos teórico-metodológicos ...........................................5 50

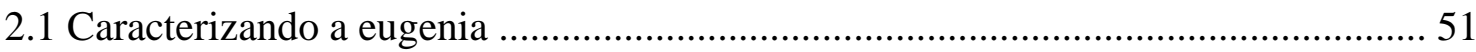

2.1.1 Variabilidade e diferenciações humanas ........................................................... 54

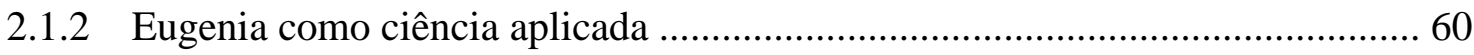

2.2 Como se escreve a História? "Nem fatos, nem geometral, mas tramas" ............... 61

Capítulo 3: O farmacêutico e médico Renato Kehl: reconhecimentos biográficos, bibliográficos e institucionais ........................................................................................... 72

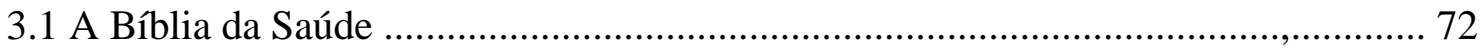

3.2 "Cada qual tem seu papel de herói ou de vilão" ...................................................... 76

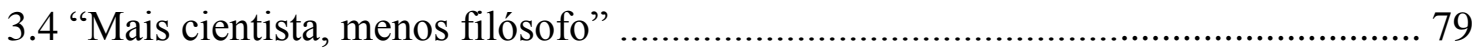

3.4 "Pelo aperfeiçoamento da nacionalidade" ............................................................ 99

3.5 "A ciência precipita sua marcha" ......................................................................... 110

Capítulo 4: Pelo progresso, contra a decadência: o túmulo da anormalidade .... 116

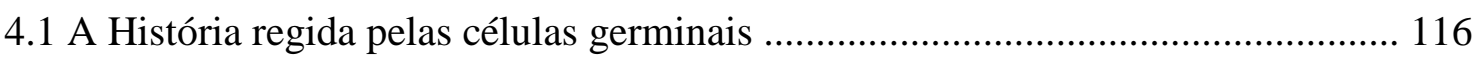

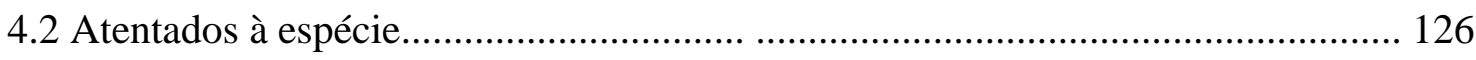

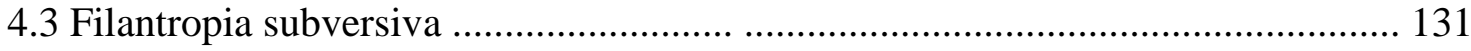

Referências ..................................................................................................................... 139 


\section{Lista de figuras}

Figura 1. Esboço esquemático dos retratos compostos. Fonte: Galton, 1883, p. 08. ................ 56

Figura 2. Reprodução da contracapa da obra Biblia da Saude (Hygiene) (1926)....................... 73

Figura 3. Fonte: Almanak Administrativo, Mercantil e Industrial do Rio de Janeiro - 1891 a

1940. Fonte: O Estado de São Paulo, 1903, p. 1563.

Figura 4. Tese Blastomycose, defendida por Kehl. Faculdade de Medicina do Rio de Janeiro,

1915.

Figura 5. Fonte: Sessão Indicador da Revista do Brasil. № 37- Anno IV. Vol. X. Janeiro, 1919... 88

Figura 6. Revista Terapêutica. №4. 1959.

Figura 7. Início do discurso de Renato Kehl quando da posse como novo acadêmico da Academia Nacional de Medicina em 1933. Acervo do Departamento de Arquivo e Documentação Casa de Oswaldo Cruz- FIOCRUZ. Fundo Renato Kehl.

Figura 8. Correspondência de Oliveira Viana. Acervo do Departamento de Arquivo e Documentação Casa de OswaldoCruz- FIOCRUZ. Fundo Renato Kehl.

Figura 9. Carta recebida de Heitor de Faria. Acervo do Departamento de Arquivo e Documentação Casa de Oswaldo Cruz- FIOCRUZ. Fundo Renato Kehl...

Figura 10. Reprodução da capa da obra Bio-perspectivas: dicionário filosófico (1938)

Figura 11. Fonte: Boletim de Eugenia. Maio de 1929. Vol. I - Num. 5. Editado em propaganda do Instituto Brasileiro de Eugenia. Capa.

Figura 12. As preocupações eugenistas de Kehl iam do coletivo ao individual. Reprodução da capa da obra Como escolher um bom marido (1935).

Figura 13. Reprodução da capa da obra Lições de Eugenia (1929) ........................................... 117

Figura 14. Reprodução da capa da obra Por que sou eugenista (1937) .................................. 122

Figura 15. Reprodução da capa da obra Catecismo para adultos (1942) ................................ 134

Figura 16. Nota de agradecimento enviada em nome do presidente Getúlio Vargas pelo recebimento da obra Catecismo para adultos. Acervo do Departamento de Arquivo e Documentação Casa de Oswaldo Cruz- FIOCRUZ. Fundo Renato Kehl. 


\section{Hereditariedade, progresso e decadência no pensamento médico-eugenista de Renato Kehl}

Prior, T. Hereditariedade, progresso e decadência no pensamento médico-eugenista de Renato Kehl [Dissertação]. São Paulo: Faculdade de Medicina, Universidade de São Paulo, 2015.

Resumo: Ao longo da história, o tema da hereditariedade apresentou-se sob interpretações variadas. O desenvolvimento das ciências biológicas permitiu, por um lado, maior conhecimento sobre seus mecanismos; por outro, tornou imprescindível a reflexão sobre determinismos teóricos que parecem recair, principalmente, sobre o campo das ciências da Saúde. A história do movimento eugenista é um evento que permite importantes reflexões sobre o passado e o presente. O termo "eugenia" foi criado por Francis Galton em 1883 para nomear uma ciência que visava o melhoramento do patrimônio biológico da humanidade. Para tanto, deveria oferecer teorias e métodos rumo à perfectibilidade física e mental. Renato Kehl (1889-1974), médico e farmacêutico paulista, foi um dos principais expoentes da eugenia brasileira, tomando para si, com afinco, a tarefa de publicista e articulador das sociedades eugênicas que aqui se formaram nas primeiras décadas do século XX. Algumas noções de progresso versus decadência contidas em suas obras em prol do movimento médico-eugenista - publicadas majoritariamente entre 1917 e 1940 - são tratadas nesta dissertação. Fizeram parte da campanha eugenista brasileira os debates acerca da esterilização dos "indesejados", das restrições matrimoniais e imigratórias e do confinamento dos chamados "denegerados". Nesse contexto o movimento eugenista foi apresentado pelos seus defensores como solução contra a supostamente inevitável e alarmante decadência que acometia o país que se formava. 
Descritores: saúde pública/história; história da medicina; eugenia (ciência); hereditariedade; bioética; filosofia médica; Brasil

Prior, T. Heredity, progress and decay through the medical and eugenic thoughts of Renato Kehl [Dissertation]. São Paulo: Faculdade de Medicina, Universidade de São Paulo, 2015.

Abstract: Throughout history the subject of heredity showed up in varied interpretations. The development of life sciences has greater insight into its mechanisms; on the other hand, it becomes indispensable to reflect on theoretical determinisms that appear to fall mainly on the field of Health Sciences. The history of the eugenics is an event that allows important reflections on the past and present. The term "eugenics" was coined by Francis Galton in 1883 to name the science of the improvement of the biological heritage of humanity. It should offer theories and methods towards mental and physical perfectibility. Renato Kehl (1889-1974), brazilian physician and pharmacist, was one of the main exponents of Brazilian eugenics, publicist and articulator of eugenic societies formed in the early decades of the twentieth century. Some notions of progress versus decay contained in his works - mostly published between 1917 and 1940 -are treated in this dissertation. Part of the Brazilian eugenics campaign debates about the sterilization of "unwanted", about marriage and immigration restrictions and confinement of so-called degenerate. In this context the eugenics movement was presented by its enthusiasts as a solution against the supposedly inevitable and alarming decay that affected the nation.

Keywords: public health/history; history of medicine; eugenics; heredity; bioethics; philosophy, medical; Brasil 


\title{
Introdução: Dimensões do passado remoto
}

Se a miséria de nossos pobres não é causada pelas leis da natureza, mas por nossas instituições, grande é a nossa culpa. (Charles Darwin, A Viagem do Beagle)

\begin{abstract}
A imagem do homem revela o que o distingue dos outros seres: sua habilidade em observar a si próprio. É a sina do homem não apenas se contentar com o que vê, mas que se aborreça com suas imperfeições físicas e mentais. A ânsia por se civilizar leva o homem a tentar melhorar não só as suas condições materiais, mas a si próprio, como um todo. Podar e cultivar: a imagem do homem é testemunho dessa ambição. (Homo Sapiens 1900)
\end{abstract}

O belo documentário Homo Sapiens 1900 (1998), obra do diretor sueco Peter Cohen, assim inicia a abordagem de seu vasto tema: a eugenia. O polêmico termo/conceito - também tema do presente trabalho - nomeia o movimento iniciado no final do século XIX que objetivava o estabelecimento de uma ciência, bem como de práticas médicas, jurídicas e políticas que cuidassem do melhoramento do patrimônio biológico da espécie humana.

Tal orientação para o melhoramento se daria pelo pretenso conhecimento teórico acerca dos caracteres hereditários desejados - que deveriam ser fomentados - e dos caracteres indesejados, que deveriam ser evitados a todo custo; bem como de ações práticas que interviessem nos mecanismos de hereditariedade. Por este aspecto, o movimento teve sua missão abraçada pelo campo médico, principalmente, durante a primeira metade do século XX, persistindo até a atualidade em algumas problematizações.

O fenômeno da formação do semelhante por descendência foi objeto de intepretações e explorações ao longo da história. Atualmente, predomina o entendimento 
da hereditariedade como um programa de tradução de mensagens, códigos, instruções. Pelas palavras do biólogo francês - agraciado com o Nobel de Fisiologia em 1965 François Jacob (1920-2013):

O que se transmite, de geração em geração, são as "instruções" que especificam aa estruturas moleculares. São os planos arquitetônicos do futuro organismo. São também os meios para executar estes planos e coordenar as atividades do sistema... O organismo torna-se assim a realização de um programa prescrito pela hereditariedade. A intenção de uma Psyché foi substituída pela tradução de uma mensagem. O ser vivo representa certamente a execução de um projeto, mas que não foi concebido por inteligência alguma. Ele tende para um objetivo, mas que não foi escolhido por vontade alguma. Este objetivo é preparar para a geração seguinte um programa idêntico. É reproduzir-se. (JACOB, 1983, p. 10)

As considerações de Jacob, trabalhadas com maestria ao longo de sua obra $A$ Lógica da Vida (1970), atentam para perspectivas reducionistas acerca da hereditariedade e, em última instância, da Biologia, que para ele não se reduz ao molecular e sim aos sistemas que, em seu inteiro, diferem das moléculas que o formam.

Estes questionamentos - que se atualizam ao longo das gerações - são de extrema pertinência para reflexões presentes, sob pena de permitirmos que nossas teorias e práticas subjuguem-se ao determinismo, por vezes sedutor, derivado do olhar segmentado. Como objeto para reflexão, propomos um retorno às origens deste evento que levou as teorias acerca da hereditariedade aos extremos embaraçosos - porém, teoricamente persistentesda intolerância.

Carrie Elizabeth Buck (1906-1983) nasceu em Charlottesville, estado da Virgínia, Estados Unidos. Filha de Emma Buck e mãe de Vivian, Carrie poderia ter levado uma vida típica não fosse uma decisão da Suprema Corte dos Estados Unidos que, em 1927, considerou seus genes hereditários perigosamente portadores da "imbecilidade". Assim, 
sob os auspícios do Ato de Integridade Racial promulgado em 1924, Carrie foi condenada à esterilização compulsória, a fim de evitar que sua imbecilidade - já comprovada na geração anterior pela história de vida de sua mãe, Emma- passasse aos descendentes e contribuísse para a decadência humana.

Médicos e juristas envolvidos no caso de Carrie Buck com muita clareza justificaram: sua mãe, Emma, havia sido internada na Colônia para Epiléticos e Débeis Mentais por conta de apresentar comportamento imoral, se prostituir e ter sífilis. Carrie, assim, foi tirada da mãe e dada em adoção para a família Dobbs. Pelo período em que frequentou a escola, obteve notas médias. No entanto, logo foi tirada dos estudos para auxiliar a família nas tarefas domésticas, tempo em que alegou ter sido estuprada por um dos sobrinhos dos Dobbs. Aos dezessete, a gravidez em decorrência do estupro de Carrie foi vista pelos pais adotivos como sinal de mau comportamento e promiscuidade, o que os fez enviá-la à mesma instituição onde havia vivido a mãe, Emma. Após o nascimento da bebê Vivian, os Dobbs a adotaram e com ela ficaram até o final de sua breve vida, que se deu aos oito anos por conta de problemas no intestino.

O caso Buck foi visto como uma vitória dos eugenistas. O anátomo-passado e a hereditariedade, afinal, seriam a grande causa das degenerações mentais e estas, por consequência imediata, da decadência da sociedade norteamericana. Prevenir era preciso: Doris, irmã de Carrie, também foi esterilizada sob ordens especiais quando precisou ir ao hospital por conta de uma apendicite. Segundo esse raciocínio, corrigia-se o passado, compensava-se o defeito humano de criar mecanismos artificiais de existência e salvavase o futuro pela eliminação das mulheres Buck (GOULD, 1999 ; GOLISZEK, 2009)

A injustiça sofrida pelas irmãs Buck, no entanto, se faz apenas 2 histórias de esterilização compulsória dentre as estimadas oito mil esterilizações que ocorrem apenas 
no estado da Virginia entre 1924 e 1970. E estes são os dados de apenas um estado dentre tantos outros que adotaram a prática pelo mundo (STERN, 2005, p. 01).

Muitos foram os desdobramentos deste movimento científico, sociopolítico e filosófico. Das consequências catastróficas às permanências que se julgam mais ponderadas, faz-se claro que a eugenia persiste e suas obscuridades permanecem.

Perante essa problematização, propõe-se aqui elementos para reflexões presentes a partir de um olhar para o passado que permite a identificação de noções deterministas da hereditariedade humana aplicadas aos estudos da mente e do corpo. Afirma-se que tais noções permearam o desenvolvimento teórico de áreas diversas, conferindo ao anátomopassado não apenas um instrumento a serviço da saúde, mas, por vezes, o poder determinante sobre o fazer-se humano. Notamos também a extensão da hereditariedade da dimensão individual para a coletiva, atribuindo poderes explicativos das supostas leis de progresso ou decadência que regiam as sociedades. Leis de decadência, diga-se, pautadas majoritariamente pelas hipóteses de degeneração mental por caracteres herdados. Ao assumir aprioristicamente a correlação entre caracteres hereditários e supostos determinantes do modo de ser em suas leis fundamentais, as teorias alocam os mecanismos da hereditariedade no cerne de suas problematizações.

Estes métodos de correlação possuem história e História, cujos aspectos serão tratados nos capítulos seguintes.

O filósofo alemão Jurgen Habermas, brilhante crítico atualmente comprometido com o tema, atenta para os riscos das práticas neoeugenistas reformuladas sob os valores do século XXI: 
Eventualmente, o "efeito horizontal" que uma prática eugênica pode ter é de natureza indireta. Ele não fere o direito de uma pessoa existente, mas em determinadas circunstâncias, reduz o status de uma futura pessoa. (HABERMAS, 2001. p.107)

Ao tratar das futuras pessoas, o debate acerca das atuais práticas eugênicas se faz, para além de importante, urgente.

A atualidade do debate é inegável. Indagações comuns se repetem: seria a eugenia - este termo de significado complexo e atributos tortuosos - erronemanente indissociável da segregação e da intolerância? Ou então: permitiria o termo-conceito uma nova interpretação, à luz de novas sensibilidades, de modo que esteja positivamente ligado aos mecanismos de obtenção da saúde e, talvez, de felicidade, que seriam conquistadas pelo fomento de caracteres hereditários satisfatórios?

O que torna estas questões sedutoras pode ser um elemento falho. Falhamos ao argumentar em prol da saúde antes de pensá-la, defini-la e de admitir seus aspectos singulares $^{1}$. Falha também seria a premissa da infalibilidade das intervenções biomédicas. Admitir que a eugenia seria capaz de nos libertar de certas condições humanas só seria possível a partir de discussões epistemológicas e filosóficas tão intangíveis quanto a totalidade da dinâmica da vida.

Questiona-se, ainda, dois pontos: 1) estaria a origem da eugenia - enquanto termo e, depois, movimento social e científico - historicamente desligada dos ímpetos restritivos e discriminatórios? Teria nascido como algo puramente humanitário? Para tal ponderação, recorreremos aos métodos e teorias da História, iniciando pelo pensamento

\footnotetext{
${ }^{1}$ Caberia, ainda, ponderar sobre o conceito de "saúde". Diante da tarefa extensa, deixamos como indicação o trabalho de José Ricardo Ayres, que disserta sobre os cuidados em saúde e resgata noções amplas de felicidade: AYRES, José Ricardo de Carvalho Mesquita. O cuidado, os modos de ser (do) humano e as práticas de saúde. Saude soc. [online]. 2004, vol.13, n.3, p. 16-29.
} 
daquele que cunhou o termo e criou as primeiras matrizes das ideias eugenistas: sir Francis Galton; 2) sobre supostos conhecimentos seguros que permitiriam que aos nossos descendentes transmitíssemos os genes mais favoráveis, dentro de uma ética irrepreensível, seriam estes conhecimentos capazes de carregar os atributos da segurança e infalibilidade? Para tal ponderação, o debate é longo, além dos limites do presente trabalho. Tais limites, no entanto, não impedem que levantemos questionamentos e que na História e na Medicina busquemos lastro para esta tão importante quanto complexa questão.

Nascido no ano de formação das primeiras instituições eugenistas, o filósofo e médico francês Georges Canguilhem, em sua revolucionária obra $O$ Normal $e$ o Patológico, atenta para a existência de uma tradição científica - em muito inspirada por Galton - que determinou limites e instaurou padrões passíveis de críticas. Padrões estes que, ao tentar mensurar as faculdades humanas, pode tê-las distanciado daquilo que são. A disciplina Fisiologia e seus parâmetros de classificação e atuação antigos teriam exemplos emblemáticos dos padrões ilusórios:

\begin{abstract}
Em primeiro lugar há de se convir que a determinação das constantes fisiológicas, pela elaboração de médias experimentais obtidas apenas no âmbito de um laboratório corre o risco de apresentar o homem normal como um homem medíocre, bem abaixo das possibilidades fisiológicas de que os homens em situação de influir sobre si mesmos ou sobre o meio são, evidentemente, capazes, mesmo aos olhos cientificamente menos informados. (CANGUILHEM, 2002, p. 126)
\end{abstract}

Admitir que a determinação das constantes fisiológicas que norteiam as práticas biomédicas é processo em permanente construção - sujeito a falhas e ajustes - permite admitir seus limites de atuação, não com o intuito de diminuí-las, mas atentar para a permanente necessidade da ampliação das objetividades e diálogos com seus objetos de estudos. Objetos, também, de cuidados. Atenta-se, aqui, para a necessidade de uma 
relação dialógica- e não fixa, determinista - entre ciências, práticas e objetos. Relação esta que pressupõe, portanto, limites.

Ao questionar os limites partimos, assim, para outra questão norteadora: do que trata a bioética? Uma perspectiva historicista apresentada pela antropóloga Débora Diniz e pela enfermeira Dirce Guilhem na obra $O$ que é Bioética? elucida: o nascimento da bioética - comumente ligado aos trabalhos do cancerologista estadunidense Van Resselaer Potter - ocorreu no campo das transformações sociais, políticas e tecnológicas da década de 1960. Afirmam as autoras que enquanto as práticas biomédicas passavam por avanços e, com eles, novos dilemas morais surgiam, os movimentos sociais organizados lutavam por conquistas no campo dos direitos civis, elevando os patamares de discussão da crítica moral. Outro ponto de convergência teria sido:

\begin{abstract}
Ainda nesse período inicial de surgimento, dois outros acontecimentos contribuíram para que a bioética fosse definida como um novo campo disciplinar: as denúncias, cada vez mais freqüentes, relacionadas às pesquisas científicas com seres humanos, um tema fortemente impulsionado pelas histórias de atrocidades cometidas por pesquisadores nos campos de concentração da Segunda Guerra Mundial; e a abertura gradual da Medicina, que, de uma profissão fechada e autoritária, passou a dialogar com os que David Rothman adequadamente denominou de estrangeiros em seu livro Estrangeiros à Beira do Leito: uma História de como a Bioética e o Direito Transformaram a Medicina: primeiro os filósofos, os teólogos e os advogados e, depois, os sociólogos e os psicólogos, que passaram a opinar sobre a profissão médica, porém sob outras perspectivas profissionais. (DINIZ \& GUILHEM, 2005, p. 17)
\end{abstract}

Emaranhados, os acontecimentos nos diversos campos contribuíram para que a bioética se estabelecesse como disciplina e se consolidasse academicamente. Como resposta aos escândalos que não cessavam de vir à tona, em 1974 o governo norteamericano formou a "Comissão Nacional para a Proteção de Sujeitos Humanos na Pesquisa Biomédica e Comportamental”. O resultado mais conhecido da Comissão foi o Relatório Belmont, onde os participantes definiram três princípios éticos: 1) respeito pelas pessoas, 2) beneficência e 3) justiça. Ou, em outras palavras: respeito pelas vontades, 
estabelecimento de avaliações - por parte do pesquisador - dos riscos/benefícios de sua pesquisa e, por fim, equidade nos tratamentos.

Da mesma maneira que o movimento eugenista havia conquistado seus primeiros espaços institucionais cerca de 70 anos antes, a bioética - como reação aos corolários catastróficos das ilusões eugenistas ocorridos durante a $2^{\circ}$ Guerra - nos anos de 1970 gozava de suas primeiras vitórias e plantou respostas que só fazem fortalecer seu campo. É possível afirmar, ainda, que a bioética como aplicação filosófica contribui para a lapidação de novas sensibilidades.

Pode-se associar a consolidação da bioética - dentro do campo de discussões acerca dos direitos humanos que se configurou no referido período pós-traumático - com os questionamentos feitos pelo filósofo Theodor Adorno que, no ano de 1965, em conferência ${ }^{2}$ transmitida pela rádio de Hessen, questionou sobre as possibilidades impulsionadoras ou impeditivas que a educação - entendida aqui em seu aspecto mais geral - poderia proporcionar. Educar contra a barbárie - e esta seria impulso intrínseco poderia impedir a ocorrência de um evento feito Auschwitz, conclui. Assim, as sensibilidades, tanto para Adorno quanto para os que pensaram e pensam a bioética, são um constructo sócio-histórico que redimiria a humanidade das mazelas de seu passado, independentemente daquilo que as causou, seja a própria condição humana, quanto propostas educativas que pensavam as sensibilidades como um empecilho para o progresso.

Em sua tese "Sobre o conceito de história" afirma Walter Bejnamin que "o passado traz consigo um índice misterioso, que o impele à redenção. Pois não somos

\footnotetext{
${ }^{2}$ Tal conferência posteriormente transformou-se em texto. Traduzido para o português pode ser encontrado em: ADORNO, Theodor W, (2003). "Educação após Auschwitz". In: Educação e Emancipação. $3^{a}$ Ed. São Paulo: Paz e Terra. Tradução de Wolfgang Leo Maar, p. 119-138.
} 
tocados por um sopro do ar que foi respirado antes?" (BENJAMIN, 1994, p. 223).

Inspirando-se em Benjamin, o mote da crítica é, portanto, compreender reducionismos cometidos no passado - já redimido - bem como seus "sopros" presentes, para refletir sobre a presente condição humana, que está além, presume-se, do ser biológico. Ao final do supracitado documentário Homo Sapiens 1900, afirma-se:

O homem, quem ele é e o que o forma continua um mistério. O homem criou uma civilização que o isola da natureza, e o deixa em conflito entre o progresso e a saudade do passado. A civilização é guiada pelo conceito de eterno progresso, que pode sempre abrir novas portas. A idéia de poder se aperfeiçoar por meios biológicos acompanha o homem há milhares de anos. A fé nas medidas transforma a idéia em ciência. A eugenia é o sonho do homem mensurável. ${ }^{3}$

${ }^{3}$ COHEN, Peter. Homo Sapiens 1900. Filme DVD. Produção: Peter Cohen. First Run Features, 2004. 85 minutos. Trecho traduzido pela autora. 


\section{Capítulo 1: A eugenia como síntese}

\subsection{Francis Galton: a vida sob os desígnios da hereditariedade}

Francis Galton (1822-1911) foi um polímata da Era Vitoriana. Viveu parte daquilo que o historiador Eric Hobsbawm chamou de "Era das Revoluções" (Hobsbawn, 2001) compreendendo os anos das revoluções Francesa, Industrial, os processos de independências latinoamericanas e a reconstrução destas sociedades após tais importantes eventos.

Na Inglaterra, viveu entre a chamada Pax Britannica - vivenciada nos anos vitorianos, que oficialmente compreendem o período do reinado da Rainha Vitória, entre 1837 e 1901 - e as turbulências sociais da sociedade que se configurava a partir das contradições do complexo século XIX.

Tal período contou com o processo de desenvolvimento e consolidação das nações e dos nacionalismos, enquanto projetos orientados para a unidade política e, pretensamente, unidade também étnico-cultural. Refletir sobre o fazer científico de Galton e sobre o movimento eugenista no âmbito dos projetos nacionalistas é crucial para a compreensão dos ímpetos diluídos em suas formulações teóricas. Ainda Hobsbawm, ao tratar das nações e nacionalismos que tiveram seu desenvolvimento no século XIX sobretudo a partir de 1780 - faz importantes considerações acerca deste processo:

\footnotetext{
...não considero a "nação" como identidade social originária e imutável. A "nação" pertence exclusivamente a um período particular e historicamente recente. Ela é uma entidade social apenas quando relacionada a uma certa forma de estado territorial moderno, o "Estado-nação"; e não faz sentido discutir nação e nacionalidade fora desta relação... As nações e seus fenômenos associados devem, portanto, ser analisados em termos das condições econômicas, administrativas, técnicas, políticas e outras exigências; por essa
} 
razão as nações são, do meu ponto de vista, fenômenos duais, construídos essencialmente pelo alto, mas que, no entanto, não podem ser compreendidas sem ser analisadas de baixo, ou seja, em termos das suposições, esperanças, necessidades, aspirações e interesses das pessoas comuns, as quais não são necessariamente nacionais e menos ainda nacionalistas. (HOBSBAWN, 2013, p.18-19)

Neste emaranhado de instâncias que formam as nações e os mitos nacionalistas está em posição de destaque também o elemento étnico ou racial, configurando o chamado nacionalismo étnico, cujas teorias se desenvolveram no mesmo campo contextual e, sobretudo, na Inglaterra. Afirma Hobsbawn:

\begin{abstract}
Ao mesmo tempo - mais ou menos na segunda metade do século XIX -, o nacionalismo étnico recebeu reforços enormes; em termos práticos, através da crescente e maciça migração geográfica; na teoria, pela transformação da "raça" em conceito central das ciências sociais do século XIX... Os liames entre o racismo e o nacionalismo são óbvios. A língua e a "raça" eram facilmente confundidas como no caso dos "arianos" e "semitas", para indignação de estudiosos escrupulosos como Max Muller, para quem a 'raça', um conceito genético, não podia ser inferida da língua, que não era herdada. Além disso, há uma evidente analogia entre a insistência dos racistas na pureza racial e nos horrores da miscigenação, e também a insistência de tantas formas de nacionalismo linguistico - a maioria, talvez - sobre a necessidade de purificar a língua nacional de elementos estrangeiros... o que trouxe a "raça" e a "nação" mais perto ainda foi a prática de usá-las como sinônimos possíveis, generalizando, de modo igualmente inexato, o caráter "racial/nacional". (Idem, p. 150-151)
\end{abstract}

A era vitoriana foi, também, propícia ao desenvolvimento científico.

Desenvolvimento este ligado ao campo social que o produziu. Vivia-se significativa prosperidade econômica conquistada com a expansão do império ultramarino e também pelas consequências das mudanças econômicas da revolução industrial: as novas fábricas implantavam novos sistemas de trabalho, aumentavam os bens de consumo, as exportações e configuravam uma nova forma de economia.

Por um lado, crescimentos econômicos e a melhora das condições materiais - para alguns - fomentavam utopias de progresso; por outro, as desigualdades se acentuavam e subjugavam, sobretudo, os trabalhadores das unidades fabris. Estes, novos moradores 
urbanos, oriundos do campo, desempenhavam trabalhos exaustivos recompensados com vencimentos baixíssimos, o que gerava dos piores panoramas: miséria e doenças. Panorama, ainda segundo Hobsbawn, ofuscado pela opulência dos anos vitorianos:

\begin{abstract}
... o quadro das condições sociais revelados pelas pesquisas da época- muitas vezes para chocante surpresa dos pesquisadores- era tétrico. Era o quadro de uma classe trabalhadora definhada e debilitada por um século de industrialismo. $\mathrm{Na}$ década de 1870 , os meninos de 11 ou 12 anos que estudavam nas escolas públicas da classe alta eram em média 12,5 centímetros mais altos que os das escolas industriais; dos 13 aos 19 anos, eram 7,5 centímetros mais altos que os filhos dos artesãos... A Grã-Bretanha era um país habitado por uma massa estoica de pessoas destinadas a passar a vida numa situação de subsistência mínima e incerta, até que a velhice as atirasse ao monturo da Lei dos Pobres, subalimentadas, mal abrigadas e mal vestidas. (HOBSBAWN, da Revolução Industrial Inglesa ao Imperialismo, p. 159)
\end{abstract}

Neste campo insere-se, assim, a história de vida de Francis Galton. Para a contemplação de seus dados biográficos nos orientamos pelo historiador François Dosse, que propõe uma abordagem hermenêutica das biografias, à luz da reflexão sobre seus elementos heterogêneos, suas vicissitudes e singularidades, em relação dinâmica com o campo social. Em sua obra O Desafio Biográfico: escrever uma vida, o historiador restitui a importância da biografia, tão singular e histórica quanto abstrata e ficcional, constituindo um gênero híbrido, passível de permanente renovação. A biografia seria, principalmente, artifício que permite lembrar e fazer recordar uma vida, passível de interpretações dialéticas entre as singularidades biográficas e o contexto histórico e social (DOSSE, 2009).

Comumente, assim se apresentam sumarizados os principais dados biográficos de Francis Galton: médico, antropólogo, geógrafo, metereologista, viajante explorador, fundador da psicologia da personalidade, inventor da identificação por impressão digital, criador da análise estatística correlacional e do conceito de regressão em direção à média, eugenista, proto-geneticista, primo do naturalista Charles Darwin e autor de best-sellers 
sobre os principais assuntos aos quais se dedicou ${ }^{4}$.

Galton também se dedicou a escrita daquela que deveria ser sua própria história, usando como método a reconstituição de sua própria árvore genealógica. Em Memories of my life - obra publicada em 1908 - apresenta breves histórias de vida de seus ascendentes, construídas segundo o mesmo método que preconizava para a compreensão da sociedade: aquele da identificação dos talentos que seriam passados de geração para geração. Talentos estes presentes nos familiares e que supostamente também se manifestaram nos filhos e netos, enfatizando sucessos e apontando limitações. Assim fez em suas Memórias em meio ao relato de anedotas e reflexões feitas sob a perspectiva dos seus quase noventa anos de idade, quando as registrou.

Para Galton, na hereditariedade encontravam-se respostas. Esta era uma questão cara e essencial ao autor, daí o caráter perene no desenrolar de suas próprias memórias. Faz-se interessante notar que em suas memórias estão presentes também as relações sociais das quais faziam parte seus entes. Sobre isso, inclusive, é constante a exaltação dos melhores relacionados. Como exemplo, temos a menção à meia-irmã de sua avó, casada com Hudson Gurney, cuja virtude era justificada por ser amigo de Lord Aberdeen, conhecido personagem histórico. No entanto, jamais atribui-se ao campo social ou às relações a função de impulsionadoras dos sucessos relatados. Como a lógica galtoniana procurava demonstrar, estes seriam baseados apenas em talentos individuais. Ou então, especificamente, talentos individuais herdados de pais com inclinações semelhantes.

Sob a perspectiva hermenêutica proposta por François Dosse apresenta-se a

\footnotetext{
${ }^{4} \mathrm{O}$ entusiasta galtoniano Gavan Tredoux assim define em texto introdutório no sítio virtual que mantêm dedicado a Francis Galton: "Victorian polymath: geographer, meteorologist, tropical explorer, founder of differential psychology, inventor of fingerprint identification, pioneer of statistical correlation and regression, convinced hereditarian, eugenicist, proto-geneticist, half-cousin of Charles Darwin and bestselling author". Disponível em: 〈www.galton.org〉. Acesso em: abr. 2013.
} 
interpretação de sua autobiografia. Adverte Galton sobre as dificuldades que encontram aqueles que optam pela empreitada autobiográfica: "It has been a difficulty througout to determine how much to insert and how much to omit. I have done my best, but fear I have failed through overmission" (GALTON, 1908, prefácio). No entanto, amparado pelas memórias privilegiadas de duas irmãs, pelas suas anotações, por alguma pesquisa e já sem a companhia dos rostos familiares - já que em sua nonagésima década de vida já havia presenciado a partida da maior parte dos amigos - o esforço autobiográfico se concretiza.

Francis Galton nasceu em 16/02/1822 em Birmingham. Pelo lado paterno, foi filho de Samuel Tertius, neto de Samuel John Galton e bisneto de Samuel Galton. Em suas Memórias afirma ser comum aos membros Galton o gosto pela leitura e o talento para cálculos estatísticos, este último manifesto sobretudo em seu pai. Tais atributos teriam formado grandes homens de negócios, com destaque para seu avô, hábil comerciante de mosquetes. Havia, ainda, em seu tio Theodore Galton esplêndidas dádivas mentais e físicas que o faziam portador da mais alta reputação na família, já agraciada com interessantes talentos. Menciona que seus familiares paternos eram Quakers ${ }^{5}$ há muitas gerações. Com seu avô, havia algumas semelhanças particulares:

\begin{abstract}
Samuel John Galton was very found of animals. He kept many bloodhounds; he loved birds, and wrote an unpretentious little book about then in three small volumes, with illustrations. He has a decidedly statistical bent, loving to arrange all kinds of data in parallel lines of corresponding lengths, and frequently using colour for distinction. (GALTON, 1908, p. 3)
\end{abstract}

Pelo lado materno, pertencia à família Darwin. Foi neto do segundo casamento do médico, poeta e filósofo Erasmus Darwin, sendo o famoso primo, Charles Darwin, neto

\footnotetext{
${ }^{5}$ Quaker é o nome dado a grupos religiosos originados a partir de um movimento protestante britânico ocorrido durante o século XVII. Liderado inicialmente por George Fox, o movimento apresentava-se como reformista e em oposição aos anglicanos, alegando uma maior aproximação com a fé a partir de inspirações diretamente divinas.
} 
do primeiro casamento. A influência hereditária do avô, afirma, teria sido muito forte, criando uma importante linhagem de médicos. Da sua avó materna teria herdado a longevidade, já que tanto ela, quanto sua mãe e seus irmãos viveram até perto dos noventa ou mais anos de idade. Uma meia-irmã de sua mãe havia se casado com Lord Byron, primo do famoso poeta. Sobre sua mãe, A. Violetta Darwin, afirma não ter sido uma mulher convencional, principalmente por seu temperamento alegre, em oposição ao comportamento aquietado dos Quaker. Além da alegria, destaca outra qualidade materna marcante: a habilidade para desenhar, reproduzindo vistas e interiores com maestria.

Ao fim de sua introdução, reconhece o que seria um débito para com seus progenitores, já que estes o agraciaram com um considerável gosto pela ciência, poesia e estatística. Reconhece, ainda, que teria herdado uma incomum capacidade física, o que o teria tornado apto a realizar fortes atividades sem sentir fadiga:

The general result of the foregoing is that I acknowledge the debt to my progenitors of a considerable taste for science, for poetry, and for statistics; also that I seem to have received, partly through the Barclay blood, a rather unusual power of enduring physical fatigue without harmful results, of wich there is much evidence when I was young. My father had this power in his early manhood, and it was well marked in my eldest brother and in others of the family. (Idem, p. 08)

No entanto, lamenta sofrer de bronquite e asma quando da escrita de suas memórias. Estes males teriam sido herdados do bisavô, Samuel Galton. Seu pai também teria sofrido com asma durante a juventude. Já ele, Galton, teria sido vítima apenas perto dos noventa anos. No entanto, não à toa, já que agora passava tempo considerável em um quente cômodo encarpetado. O carpete, assim, poderia, assim, redimir os caracteres herdados de seu avô:

I suffer now from bronchitis with occasional asthma, wich has been traced to my great-grandfather, Samuel Galton, and has descended in a greater or less degree through all his children who left issue. My father had a strong 
constitution otherwise, but He suffered terribly from hay asthma, wich first attacked him as a youth. I escaped fairly well from any form of it until I was nearly eight years old; and it is not hay that specially brings it on now, but warm carpeted rooms. (Ibidem, p. 11)

Após a morte de Galton, o estatístico Karl Pearson (1857-1936) - seu amigo pessoal e colega profissional, com quem divide os méritos históricos da criação da Estatística como disciplina e pela criação de conceitos fundamentais utilizados até a atualidade- ocupou-se da escrita de uma vasta biografia, dividida em três volumes publicados entre 1914 e $1930^{6}$. O empreendimento teria sido feito a partir do Laboratório Galton, com sede na University College de Londres.

A obra, intitulada The life, letters and labours of Francis Galton, divide-se entre períodos da vida e temas aos quais se dedicou Galton entre seu nascimento e o casamento, ocupando o volume I; as pesquisas que realizou em sua meia-idade, ocupando o volume II; os conceitos de correlação, identificação pessoal e eugenia, ocupando o volume III-A e, por fim, caracterizações e cartas diversas, no volume III-B.

Ao início do oitavo capítulo do segundo volume, afirma Person sobre o amigo:

\begin{abstract}
His experience had been such that he knew more of mathematics and physics than nine biologists out of ten, more of biology than nineteen mathematicians out of twenty, and more of pathology and physiology than forty-nine out of fifty biologists and mathematicians of his day. Added to these advantages he had gained a knowledge of man and his habits in various lands; this gave him additional width of view, if it rendered less obvious to him that field of investigation wherein his powers were ultimately to achieve their most noteworthy successes. (PERSON, 1924, p. 161)
\end{abstract}

A reconstrução dos aspectos da vida e das empreitadas científicas de Galton feitas por Person são, assim, marcadas por comentários altamente elogiosos ao amigo. Tendo

\footnotetext{
${ }^{6}$ A versão digitalizada da obra encontra-se disponível em: 〈http://galton.org/galton/pearson/index.html $>$. Último acesso em: nov. 2015.
} 
sido agraciado pela hereditariedade, o cientista carregaria aqueles caracteres positivamente excepcionais, tal como indicavam suas pesquisas que, ao procurar as constantes e médias humanas, visavam identificar supostos traços biológicos de indivíduos que as superavam. Pelas palavras de Person no prefácio ao último volume, esta teria sido a contribuição de Galton para a revolução no pensamento humano que ocorreu naquele último quarto do complexo século XIX (PERSON, 1930, p. 56).

\subsection{Eugenia: uma breve palavra para nomear a ciência do melhoramento da espécie}

O tema da hereditariedade foi, portanto, o propulsor de boa parte dos escritos galtonianos. Saindo de suas memórias para os estudos acadêmicos, destaca-se o especial interesse por estudos sobre as aptidões e sensações humanas - desde a capacidade de levantamento de peso aos testes de inteligência psicométricos. Sobre este assunto, acumulou dados desde a década de 1860, publicando artigos pontuais e, posteriormente, compilando suas conclusões no ano de 1883 com a obra Inquiries into human faculty and its development. Na longa extensão da obra, um marco: ali cita a palavra eugenia pela primeira vez, cunhando o termo-conceito que originou um movimento e uma pretensa nova forma de ciência, com aspecto teórico e prático, ou aplicado. Pelas palavras do filósofo Valdeir Del Cont:

A carreira intelectual de Francis Galton pode, assim, ser dividida em duas fases distintas, antes e depois de 1860 . Na primeira fase, seus trabalhos foram os resultados de inúmeras viagens de exploração e de um conjunto de estudos sobre metereologia, impressão digital e o interesse em qualquer assunto que pudesse ser medido, como bem ilustra a sua tentativa de medir a eficácia da oração (KEVLES, 2001, pg. 11). Após 1860, durante uma forte crise nervosa, encontrou consolo e orientação ao ler a obra A origem das espécies, de seu primo Charles Darwin, o que contribuiu para mudar significativamente a sua vida no sentido de tentar aplicar a teoria da seleção natural no estudo do ser humano e de suas potencialidade físicas e intelectuais. (DEL CONT, 2008, p. 
Acerca dos aspectos práticos e aplicáveis dos conhecimentos sobre a hereditariedade, ainda em suas Memórias Galton narra as tentativas iniciais para a criação de laboratórios de antropometria, onde medições humanas das mais variadas deveriam ser realizadas com frequência. Assim, seria possível coletar e fornecer dados sobre as faculdades e capacidades humanas, estabelecer médias, padrões e desvios para as orientações eugênicas. A primeira das tentativas teria sido convencer o reitor da Marlborough College a incentivar a pesagem e medição de seus alunos. Tal evento teria tido sucesso e fornecido importantes elementos para seus escritos. Em artigo que escreveu após as medições, afirma Galton:

When shall we have Anthropometric Laboratories, where a man may from time to time get himself and his children weighed, measured, and rightly photographed, and have each of their bodily faculties tested, by the best methods known to modern science? (GALTON, 1908, p. 244-245)

Em 1869, Galton publicou uma importante obra na qual tratou especificamente dos talentos e capacidades intelectuais, com o intuito de fornecer embasamento científico que corroborasse a premissa de que as faculdades mentais poderiam ser mensuradas, administradas e, uma vez definidas quais eram as desejadas para o futuro de uma sociedade, estas deveriam ser estimuladas por meio de casamentos específicos. Buscou, assim, demonstrar que as supostas boas qualidades tinham como lei fundamental a respectiva boa ascendência. Para tanto, Galton aplicou testes e analisou histórias de vida e árvores genealógicas - tal como fez consigo - de homens considerados eminentes. Analisou as reputações, talentos naturais e ascendência de juízes, literatos, cientistas,

\footnotetext{
${ }^{7}$ Utilizamos a versão digitalizada do artigo, disponível em $\langle$ http://www.scielo.br/scielo.php?script=sci arttext\&pid=S1678-31662008000200004〉. Acesso em: out. 2015.
} 
poetas, musicistas, membros notáveis de Cambridge, lutadores e, indo além, estabeleceu tabelas comparativas entre raças e nações. O objetivo maior seria a orientação científica para a produção de uma raça de humanos melhores dotados, tal qual se fazia com cachorros e cavalos. No capítulo introdutório afirma que as evidências reunidas deveriam obter a aceitação do primo Darwin, com quem travou intenso debate (GALTON, 1869, p. 09).

Ainda no início de sua obra, Galton deixa claro que não possui "paciência" para o argumento de que os humanos nascem igualmente dotados. Não haveria, segundo o autor, equidade natural. Partindo dessa premissa, parte para a análise das autobiografias a fim de corroborar não só a hierarquização inata, como sua causa hereditária.

Dando sequência aos estudos e publicações publicou em 1883 a supracitada obra Inquiries into Human Faculty and its development. Previamente, seu Hereditary Genius, bem como o Hereditary Improvement, publicado em 1873, já haviam alcançado certo sucesso e lançado as raízes do ideal eugênico, ambos inspirados pela ideia de evolução por seleção natural contida na obra de Charles Darwin.

Inquiries apresenta o estudo pormenorizado de determinadas capacidades mentais e características físicas humanas, sobretudo aquelas que, segundo o autor, eram configuradas por caracteres hereditários. No breve prefácio à segunda edição, publicada em 1907, Galton afirma em duas ocasiões aquilo que para ele a obra havia se tornado passados vinte e quatro anos de sua primeira publicação: ponto de partida para uma profusão de estudos na Inglaterra e nos Estados Unidos. O movimento eugenista tomava forma e Inquiries era visto como um marco:

I shrank from the great trouble of bringing it up to date because it, or rather many of my memoirs out of which it was built up, had become starting-points for elaborate investigations both in England and in America, to which it would 
be difficult and very laborious to do justice in a brief compass... Since that time the book has by no means ceased to live, for it continues to be quoted from and sougth for, but is obtainable only with difficulty, and at much more than its original cost, at sales of second-hand books. Moreover, it became the starting-point of that recent movement in favour of National Eugenics which is recognized by the University of London, and has its home in University College. (GALTON, 1883, prefácio)

Galton segue sua obra atentando para a necessidade de se deixar de lado os preconceitos para se julgar corretamente em quais aspectos as diferentes raças devem ser melhoradas. A diversidade da natureza humana seria tão complexa e profunda quanto se pode observar nos animais em jaulas nos zoológicos. Dentre as variações, admite a persistência de elementos degenerados que positivamente poderiam ser nocivos. Sobre tais elementos, afirma, o julgamento é passível de erro. Mas a probabilidade de erros não impediria admitir que cada raça humana seria passível de melhoramentos fáceis de serem especificados. Esta obra seria uma compilação de resultados norteadores destes melhoramentos.

Entre o estabelecimento de médias referentes às cores dos cabelos, estaturas e capacidades diversas, Galton apresenta sua nova e elucidativa técnica: os retratos compostos. Tal técnica sumariamente consistia em coletar retratos de pessoas diferentes, com mesma luz e sombra, equiparar os tamanhos das imagens, utilizando linhas de referências comuns, montar um livro com estas imagens superpostas e analisar os traços e detalhes comuns. O objetivo era - a partir de minuciosa análise - encontrar traços étnicos ou traços comuns entre saúde, doença e criminalidade. Maiores explicações sobre a técnica são apresentadas no próximo capítulo.

O capítulo próximo discorre sobre as qualidades corporais. Estas bodily qualities, afirma Galton, são essenciais para a compreensão de uma sociedade. Justificavam-se sucessos e mazelas de acordo com médias gerais das capacidades físicas de seus 
habitantes. Os casos mais graves e tristes estariam fora da vista, confinados em hospitais ou prisões. E para ele não haveria visão mais triste do que os portadores de imperfeições congênitas, como a fraqueza, por serem impedimentos para o bom funcionamento social.

Neste capítulo é apresentado o termo eugenia:

That is, with questions bearing on what is termed in Greek, eugenes namely, good in stock, hereditarily endowed with noble qualities. This, and the allied words, eugeneia, etc., are equally applicable to men, brutes, and plants. We greatly want a brief word to express the science of improving stock, which is by no means confined to questions of judicious mating, but which, especially in the case of man, takes cognisance of all influences that tend in however remote a degree to give to the more suitable races or strains of blood a better chance of prevailing speedily over the less suitable than they otherwise would have had. The word eugenics would sufficiently express the idea; it is at least a neater word and a more generalised one than viriculture which I once ventured to use. (Idem, p. 17)

A origem do termo remete à palavra grega eugenes, que deveria significar "bemnascido" ou "hereditariamente agraciado com nobres qualidades". Não por acaso buscou na Grécia a origem do termo, sendo que a visão romantizada da história grega propõe sociedades de habitantes com aptidões físicas e mentais superiores, quando não insuperáveis em outros tempos e espaços.

Aplicável aos homens, animais e plantas, o termo viria nomear a ciência do melhoramento da espécie humana, especificamente do estudo dos meios para que as melhores raças e estirpes prevalecessem em detrimento das menos adequadas.

"Viricultura" - termo por ele utilizado anteriormente não teria a abrangência que desejava. A nova ciência deveria, afinal, dar conta do conhecimento de todas as influências que fariam os homens como são e auxiliar aqueles que, uma vez conhecidos seus caracteres hereditários, deveriam transmiti-los, bem como o sentido oposto, que seria o impedimento dos que não deveriam transmitir suas características.

Estudioso dos movimentos eugenistas, o historiador estadunidense Daniel J. 
Kevles apresenta importante reflexão sobre a origem dos estudos sobre hereditariedade no século XIX - estes não exclusivamente realizados por Galton, mas também por uma série de colegas acadêmicos, como Charles Davenport e Karl Pearson - e sobre o que estes estudos representavam na época:

Francis Galton, innocent of the future, confidently equated science with progress. All around him the technology of the industrial revolution confirmed man's mastery over inanimate nature. To be sure, in the mid-Vitorian era, heredity in plants and animals was less a science than a body of lore based on empirical practice. In the common understanding, scientific and otherwise, like tended to produce like, although in fact like often produced something quite differente. Ideas of human heredity were particularly vague and contradictory. The science of genetics - indeed, the word 'genetics' itself-had not yet been invented. Gregor Mendel's paper, the foundation of that discipline, was not only unappreciated but generally unnoticed by the scientific community. Nevertheless, it was well known that by careful selection farmers and flower fanciers could obtain permanent breeds of plants an animals strong in particularly characters. 'Could not the race of men be similarly improved?' Galton wondered. 'Could not the undesirables be got rid of and the desirables multiplied?' Could not man actually take charge of his own evolution? (KEVLES, 1995, p. 03)

A passagem escrita por Kevles atenta para a necessidade da ponderação: seria Francis Galton um inocente perante o futuro, praticante de uma ciência “menor", baseada em práticas empíricas? Atenta-se, aqui, para o risco de anacronismo ao considerar que as ideias inicialmente eram vagas, "apenas" ímpetos baseados em observações e a ânsia por impedir que os "indesejados" procriassem. Tais problematizações, historicamente persistentes, não permitem, discordando de Kevles, o julgamento de Galton por sua inocência por ser anterior aos conhecimentos- igualmente passíveis de crítica- acerca dos mecanismos da hereditariedade dos séculos XX e XXI.

Em artigo intitulado "Das ervilhas mendelianas ao 'décimo submerso'. Aspectos teóricos e práticos do desenvolvimento da eugenia nos Estados Unidos”, Rodrigo Andrade da Cruz, ao estudar os trabalhos do biólogo Charles B. Davenport - eugenista estadunidense, fundador do Eugenic Record Office - atenta para as certezas que estes 
cientistas que criavam a eugenia já demonstravam ter. Os determinantes hereditários ganhavam força e credibilidade. Partindo das abordagens estatísticas e da aritmética, Davenport considerava já "possível enxergar claramente o método de transmissão de um grande número de traços humanos" (CRUZ, 2003. p.41).

Não obstante os julgamentos atuais acerca da validade científica das teorias que embasaram o eugenismo, é certo que à época eram coerentes aos olhos daqueles que fizeram dela uma ciência e mesmo dos opositores que a arguiram. Pondera Del Cont:

\begin{abstract}
Mesmo não possuindo uma teoria suficientemente clara para a descrição do mecanismo da hereditariedade, a simples frequência observada por Galton já era um bom indicador de que as leis que governam tal fenômeno seriam em breve desvendadas. Os seus estudos antropométricos e antropológicos, principalmente em terras africanas, ofereciam-lhe o material necessário para reconhecer que, quando as características e os talentos dos indivíduos eram analisados em termos de distribuição em uma dada população assemelhada, a influência do meio cedia espaço para a regularidade e manutenção das características e dos talentos transmitidos de uma geração para outra (cf. KEVLES, 2001, p. 08). Quando se analisava, por exemplo, as alturas dos indivíduos em uma população, percebia-se uma constante de regressão à média, indicando que indivíduos em seus extremos deixaram descendências que tendiam ao valor médio. Essas disposições não estariam sujeitas às condições ambientais, tais como nutrição, clima, geografia, sendo, portanto, o resultado da herança de caracteres inatos, ou seja, transmitidos sem sofrerem influência das condições externas. Com isso, Galton pretendia estabelecer uma clara distinção entre o que poderia ser considerado consequência de forças inerentes às condições naturais ou biológicas e o que poderia ser considerado consequência das condições nutritivas, educacionais e culturais. Essa distinção é expressa na relação que Galton estabeleceu entre nature and nurture. (DEL CONT, 2008, p. 06)
\end{abstract}

É certo que o pensamento galtoniano tendia a considerar a determinância dos caracteres hereditários sobre as faculdades mentais e físicas, tal como explicitou em diversas passagens de suas obras, principalmente no Hereditary Genius. O dilema nature and nurture, porém, foi perene nos debates acerca daquilo que determinava o ser e fazerse humano. A importância do debate - que se atualiza ao longo das gerações - se dá para além das discussões científicas daquele contexto, sendo que permitiu, em diferentes tempos e espaços, uma grave justificativa científica para medidas restritivas e intolerantes 
em prol de um ideal de progresso.

\section{$1.3 O$ contexto evolucionista}

Os conhecimentos sobre a hereditariedade possuem longa e complexa História, cuja abordagem satisfatória encontra-se além dos limites do presente trabalho. No entanto, cabem considerações acerca de teorias que se relacionam com a origem da eugenia e com o contexto intelectual de Galton, sobretudo, os evolucionismos teorizados durante o século XIX. Estes, por sua vez, fazem parte de um contexto específico de mudanças nas ciências naturais.

Para a compreensão destas mudanças é pertinente o retorno cronológico à chegada dos europeus ao "Novo Mundo", processo que proporcionou o contato com novidades que frutificaram na economia e nas ciências. Sobre esta relação do fazer científico com o mundo possível diz François Jacob:

Cada época se caracteriza pelo campo do possível, que é definido não somente pelas teorias ou crenças em curso, mas pela própria natureza dos objetos acessíveis à análise, pelo equipamento para estudá-los, pela maneira de observá-los e de falar sobre eles. É somente no interior desta zona que a lógica pode evoluir. É no interior dos limites assim fixados que as ideias se movem, se testam, se opõem. Entre todos os enunciados possíveis, trata-se então de escolher o que melhor integra os resultados da análise. É aí que o indivíduo intervém... Durante muito tempo se perguntará o que teria acontecido com o pensamento científico se Newton tivesse sido coletor de maçãs, Darwin capitão de longo curso e Einstein o encanador que ele lamentava não ter sido. Na pior das hipóteses, teria provavelmente havido alguns anos de atraso para a gravitação ou para a relatividade. (JABOB, 1983, p.19)

Sobre o contexto evolucionista, pondera:

Menos ainda em relação à evolução, que Wallace anunciava ao mesmo tempo que Darwin. Quando uma concepção manifesta-se muito cedo, como a de 
Mendel, ninguém a leva em consideração. Quando se torna possível para o pequeno número de especialistas, então a encontramos em muitos lugares ao mesmo tempo. Mas, em compensação, uma vez aceitas, as teorias da ciência contribuem mais que as outras para reorganizar o domínio do possível, para modificar a maneira de considerar as coisas, para dar origem a relações e a objetos novos; em suma, para mudar a ordem em vigor. (Idem)

Pelas matrizes de pensamento que se tornaram, vale deter-se em alguns aspectos das obras naturalistas que, pelas décadas - e mesmo séculos - que seguiram ao contato com o Novo Mundo forneceram subsídios para o movimento em questão; o tom usualmente laudatório por vezes obscurece os embates filosóficos, as tramas pessoais e institucionais envolvidas, construindo imagens do passado um tanto simplistas. Opta-se, aqui, pelos aspectos pertinentes ao contexto intelectual da eugenia e algumas mudanças nas concepções filosóficas e científicas que embasaram uma nova história natural e, também, uma nova concepção do mundo.

Tão logo se depararam com as novidades do "Novo Mundo", os europeus que se ocupavam das ciências sobre elas se debruçaram e iniciaram seus estudos. As plantas diversas, por suas possibilidades lucrativas ou para usos pessoais e medicinais passaram a ser colecionadas e catalogadas. O intuito era classificá-las e descrevê-las. O mesmo ocorria com amostras de animais e minerais. À medida que as coleções - bem como o interesse por este tipo de conhecimento - cresciam, eram criadas novas metodologias para classificá-las.

Na obra Uma História da Ciência: experiência, poder e paixão, afirmam Michael Mosley e John Lynch:

A observação da natureza, contudo, era bem mais que um mero passatempo. Na natureza, em especial nas plantas, estão os fundamentos do poder imperial. A descoberta da América revelara uma profusão de riquezas naturais. (MOSLEY \& LYNCH, 2010, p. 104) 
Ao naturalista britânico John Ray, responsável pela classificação de 18 mil espécies vegetais, é atribuída na supracitada obra a criação de conceito moderno de espécie. O sueco Carl Linneus, partindo dos estudos de Ray, criou um sistema de classificação utilizado até os dias atuais. Este sistema partia da ideia, então revolucionária, de que as plantas reproduziam-se sexuadamente e, assim, poderiam ser classificadas de acordo com seus órgãos complementares, sendo eles os estames e pistilos. As plantas e animais foram divididos em três reinos, subdivididos em classes, ordens, gêneros e espécies, de maneira hierárquica, cuja nomenclatura binomial remetia ao posicionamento na natureza. A obra Systema Naturae, cuja primeira edição se deu em 1735, consistiu numa importante enciclopédia com doze mil espécies catalogadas.

Paralelamente, a consolidação da indústria inglesa promovia um significativo aumento nas obras de grande porte - como a construção de canais para transporte de carvão - possibilitando uma maior exposição dos níveis mais profundos do solo. Uma vez expostas, as observações realizadas permitiram um maior conhecimento sobre as rochas, suas “imperfeições” e, sobretudo, dos fósseis. Se a noção de que os fósseis eram constituídos por restos de animais mortos era antiga, as novidades que apareciam com o aumento das escavações - principalmente em França e Inglaterra - apresentavam vestígios incomuns, sugerindo novos questionamentos que, por vezes, eram "incômodos" para os pressupostos da época.

Georges Cuvier, naturalista francês que trabalhava no Museu de História Natural de Paris e demonstrava grande habilidade como anatomista, passou a receber e ser consultado sobre estas descobertas de fósseis suspeitos. A partir da observação e aplicação da anatomia comparada, publicou um estudo sobre a ossada de um suposto elefante, alegando se tratar de uma outra espécie: o mamute. Este, no entanto, estaria extinto. A noção de extinção foi, desta maneira, se configurando e suscitando polêmicas. 
Aquelas acerca dos propósitos divinos foram as mais acaloradas, uma vez que a constatação da existência de espécies que não mais habitavam o planeta feriam as explicações usuais acerca da origem divina da vida. Diante disso, o próprio Cuvier sugeriu uma solução: a história natural do planeta teria sido marcada por diversas catástrofes que promoveram a extinção de algumas espécies, mas que posteriormente foram substituídas por outras. Lançava-se a teoria conhecida por catastrofismo, que angariou importantes adeptos, como Louis Agassiz, Richard Owen e Alcide D’ Orbigny.

Independente da aceitação ou não da teoria proposta por Cuvier, os importantes questionamentos suscitados pelos fósseis tiveram consequências importantes. Uma delas foi a necessidade de se repensar a datação da terra, até então com início estimado em cerca de 4.000 a.C., segundo cálculos até então bem aceitos do bispo irlandês James Ussher, de Isaac Newton e de Johannes Kepler. Pelas palavras de Jacob sobre o impacto desta teoria da revolução:

\begin{abstract}
O desaparecimento da geração espontânea e o aparecimento de uma teoria da revolução tornam-se produtos de meados do século XIX em seu conjunto. Introduzem o conceito de vida e o de história no conhecimento dos seres. Só podem surgir quando se delimita a espécie, quando se rompe a continuidade entre o orgânico e o inorgânico, quando se elimina a série de transições que conduzia imperceptivelmente os organismos mais simples aos mais complexos. No final das contas, por sua rigidez e seu dogmatismo, por sua obstinação em só considerar a fixidez das espécies, Lineu e Cuvier contribuíram tanto quanto Redi e Spallanzani, com suas experiências, para eliminar a geração espontânea. E, rompendo o velho mito da cadeia dos seres vivos, Curvier talvez tenha feito mais para tornar possível uma teoria da evolução que Lamarck generalizando o transformismo nodo século XVIII. (JACOB, 1983, p. 19-20)
\end{abstract}

A nascente disciplina da geologia se incumbiu da importante questão. GeorgesLouis Leclerc, conhecido por Conde de Buffon, geólogo e naturalista francês, partindo do pressuposto de que a Terra teria se originado a partir de matérias que orbitavam ao redor do Sol, supôs que o cálculo deveria ser estimado a partir do tempo do processo de resfriamento da mesma, que forneceria todas as respostas. Seus cálculos chegaram ao 
número de 75 mil anos e foram publicados, no ano de 1749, na obra L'Histoire Naturelle. A obra de Buffon, tida como exemplo de maestria da biologia descritiva, ainda sugeria a possibilidade das espécies sofrerem mudanças com o tempo e terem passado por processo de migração pelo planeta.

Estas novas possibilidades para a datação terrena inspiraram a noção de tempo profundo. Em oposição ao catastrofismo, James Hutton propôs - a partir da observação de rochas em Siccar Point realizadas em 1788 - que os processos geológicos eram de longa duração e contínuos, ocorrendo gradualmente e não abruptamente, por meio de catástrofes, como proposto por Cuvier e adeptos. Baseando-se neste pressuposto, o conceito de uniformitarismo polemizava ao afirmar que as rochas, por sua formação, não indicavam indícios de começo ou de fim.

O uniformitarismo, surgindo como teoria, teve importante contribuição de Charles Lyell, um estudante de geologia que, ao visitar o templo de Serápis em Pozzuoli, na Itália, percebeu ali vestígios de transformações surpreendentes: havia colunas cujos topos apresentavam marcas de moluscos, formando um indicativo de que ao longo dos séculos as mesmas haviam estado submersas. Prosseguindo com as observações, constatou que o monte Etna era formado por camadas sucessivas de lavas que teriam se disposto lentamente, culminando no tamanho que então apresentava. Seria este mais um forte indício do uniformitarismo, que trazia em seu cerne a noção de transformação e evolução:

\footnotetext{
A tese implicava admitir que a Terra era bem mais antiga do que se estimava. Nas célebres palavras escritas por Hutton em Teoria da Terra, 'não vemos vestígio algum de começo, nenhuma expectativa de fim'. Estava armado o palco para uma batalha intelectual. (MOSLEY \& LYNCH, 2010, p. 122)
}

Vestiges - the natural history of creation foi uma obra publicada no ano de 1844 pelo editor escocês Robert Chambers, tendo alcançado certo sucesso quando da 
publicação, mas relativamente pouco comentada na posteridade. Sob críticas de falta de rigor científico, a obra sintetizava uma nova teoria sobre a vida na terra; teoria de cunho transformista e progressista. A estes processos de mudanças estariam sujeitos toda a humanidade e o meio natural, abrangendo assim as ideias uniformitaristas e mesmo a questão das extinções. As mudanças lentas e graduais se dariam, portanto, pela transmutação, nome dado a este novo conceito ou mesmo teoria.

Chambers propunha que as espécies, uma vez originadas por geração espontânea, progrediriam para novas formas de vida, gradualmente, sempre partindo das formas consideradas mais simples para as mais complexas como, por exemplo, dos insetos aos mamíferos. Sendo um processo de longa duração ou, em outras palavras, de tempo profundo, este não sofreria interferência direta dos propósitos divinos, apenas obedeceriam ao desígnio divino pré-estabelecido na forma da lei natural primeira da transmutação. Sabe-se que, assim como ocorreu com a famosa obra de Darwin, Vestígios também se esgotou rapidamente. No entanto, duras acusações de falta de rigor científico acabaram por levá-lo ao anonimato. Há, contudo, os que consideram Chambers um dos pioneiros na empreitada que buscava responder a existência da vida pelo nascente paradigma evolucionista.

Marcel Blanc, na obra Os Herdeiros de Darwin atribui ao zoólogo francês Jean Baptiste de Lamarck (1744-1829) o mérito pela elaboração da primeira teoria evolucionista com respaldo científico que fosse baseada na ideia de que a transformação - daí o termo transformismo - se dava pela mudança das condições de vida imposta pelo meio ambiente. A adaptação, elemento crucial do transformismo lamarckista, era acompanhada da noção de gradação nos seres vivos, rumo à complexidade e, em última instância, à perfectibilidade. Concordando com sua concepção deísta, estaria o homem no topo desta hierarquia, que tinha como base os animais considerados mais simples, como 
os vermes, passando por insetos, moluscos, peixes, répteis, aves e, por fim, mamíferos. Essa ideia existia desde a Antiguidade e Lamarck foi o primeiro a apresentá-la fundamentada cientificamente, acrescentando-lhe um importante elemento: a ideia de que houve espécies que existiram e se extinguiram, senão abruptamente, mas transmutaramse a ponto de tornarem-se novas espécies.

As teorias evolucionistas surgiram, portanto, em momento propício, não se tratando de uma única obra autoral. O próprio Charles Darwin, autor sobre o qual quase todo o mérito recaiu, observou a existência de cerca de 20 estudiosos que, antes dele, dissertaram sobre a transmutação das espécies ao longo do tempo.

Darwin publicou sua obra On the Origin of Species by Means of Natural Selection, or the Preservation of Favoured Races in the Struggle for Life no ano de 1859. O título, posteriormente sintetizado em The Origin of Species, tornou-se uma literatura científica consagrada, cujas ideias transverberaram para campos do conhecimento diversos causando, sobretudo pelas polêmicas que suscitou, impacto social significativo. A primeira edição d'A Origem das Espécies esgotou-se já no primeiro dia de seu lançamento e, desde então, já foi traduzida para trinta línguas, em reedições que não cessam.

A produção científica de Darwin é notável pela abrangência de temas e volumes. Desde o ano de 1837 ao ano de 1881, publicou os resultados de suas pesquisas em obras que trataram de zoologia, botânica e geologia. A diferenciação das espécies, suas classificações e subdivisões configuravam os temas principais. Entre suas observações - como as realizadas no famoso episódio de sua expedição de estudos a bordo do navio Beagle - aquela que sugeriu a evolução das espécies a partir de ancestrais comuns, em processo que se dava por meio da seleção natural dos seres por capacidade de adaptação - esta adaptação, por sua vez, ocorrida a partir de mutações ao acaso que acabavam por 
fornecer mais chances de sobrevivência em determinado meio - foi a que maior impacto causou e mais frutos gerou, sendo um dos pilares das ciências biológicas e sociais até a atualidade. Suas bases científicas e ideológicas - se for admitida a separação dessas duas instâncias - bem como as polêmicas, renovam-se constantemente.

Se a questão do pioneirismo gera controvérsias, é certo que foi o trabalho autoral de Darwin que ganhou maior notoriedade. A sistematização do mecanismo de seleção natural como fator para a evolução causou polêmica tão logo os primeiros exemplares foram lidos. Vale ressaltar que Darwin não desconsiderava a proposta lamarckista e mesmo a pangênese, teoria que foi superada apenas anos depois. Entre seus inúmeros interlocutores, entre críticas ferrenhas e defensores incondicionais, estava o primo Francis Galton. Sobre a dimensão desta teoria em seu contexto e na posteridade, valem as considerações de Jacob:

\begin{abstract}
Em biologia, existe um grande número de generalizações, mas poucas teorias. Entre estas, a teoria da evolução ocupa um lugar mais importante que as outras, porque reúne uma massa de observações oriundas dos mais diversos domínios que, caso contrário, permaneceriam isoladas; porque inter-relaciona todas as disciplinas que se interessam pelos seres-vivos; porque instaura uma ordem na extraordinária variedade dos organismos e liga-os estreitamente ao resto da Terra; em suma, porque fornece uma explicação causal do mundo vivo e de sua heterogeneidade. A teoria da evolução se resume essencialmente em duas proposições. Em primeiro lugar, diz que todos os organismos, passados, presentes ou futuros, descendem de um ou de poucos sistemas vivos que se formaram espontaneamente. Em segundo lugar, diz que as espécies derivaram umas das outras por seleção natural dos melhores reprodutores. Para uma teoria científica, a teoria da evolução apresenta o mais grave dos inconvenientes: como se baseia na história, não se presta a qualquer verificação direta. (JACOB, 1983, p. 21)
\end{abstract}

Paralelamente, o monge Gregor Mendel (1822-1884) realizou, principalmente entre 1856 e 1865, uma série de experimentos com ervilhas, com o objetivo de compreender como as características hereditárias eram transmitidas de pais para filhos. Em 1865 apresentou um importante trabalho à Sociedade de História Natural de Brunn, 
mas por razões diversas este ficou desconhecido até o início do século XX. Entre as principais premissas do modelo teórico proposto por Mendel, tem-se que as características de um ser são determinadas por fatores hereditários presentes aos pares em um indivíduo. Um dos fatores seria herdado do "pai", o outro da "mãe". Estes fatores seriam imutáveis, não sofrendo influência do ambiente, mas apenas do processo de segregação dos fatores ocorrido durante a formação dos gametas. Esta noção que propõe a não interferência do meio e sim de constantes no mecanismo de hereditariedade foi muito importante para o movimento eugenista. Nota-se que no contexto qual foi defendida a tese de Mendel não obteve imediato reconhecimento, o qual veio depois, quando a teoria forneceu as equações para a lei fundamental da genética e para os estudos eugenistas, por mais que a resposta que os eugenistas e geneticistas pioneiros encontraram no trabalho de Mendel não tenha sido exatamente uma resposta para a pergunta que motivou a problematização do monge ao estudar a frequência dos caracteres nas gerações das ervilhas ${ }^{8}$. Ainda Jacob afirma:

Entre aqueles que no século XIX, até Mendel, se interessavam pela hereditariedade, há apenas uma ligeira diferença na escolha dos objetos de experiência, no que neles se observa e sobretudo no que se coloca de lado. E se a obra de Mendel permaneceu ignorada durante mais de trinta anos, foi porque nem os biólogos de profissão, nem os criadores, nem os horticultores tinham condições de adotar seu ponto de vista. "Aqueles que procuram Deus o encontram”, dizia Pascal. Mas só se encontra o Deus que se procura. (JACOB, 1983, p. 21)

Nota-se, portanto, a configuração de um contexto intelectual especificamente evolucionista, tendo como pilares ideias de transformação que, traduzidas em noções de

\footnotetext{
${ }^{8}$ Há um importante debate acerca da coerência entre as teorias de Darwin e de Mendel, onde questiona-se e aponta-se o caráter especulativo da síntese entre as duas, assim como o processo de especialização que levou as leis de Mendel a transformarem-se nas leis fundamentais da genética clássica. A extensa discussão é conduzida com maestria pelo filósofo das ciências Pablo Lorenzano, adepto da metateoria estruturalista. Sobre a discussão, destacamos dois artigos: "What would have happened if Darwin had known Mendel (or Mendel's work)?”, publicado na History and Philosophy of the life Sciences, vol. 33, n¹ (2011); e o capítulo "Leyes fundamentales, refinamientos y especializaciones: del 'mendelismo' a la 'teoria del gen"” in: Lorenzano, P. and F. Tula Molina (eds.), Filosofía e Historia de la Ciencia en el Cono Sur (Philosophy and History of Science in the South Cone), Quilmes: National University of Quilmes, 2002, p. 379-396.
} 
progresso, seduziam e tornavam-se verossímeis sobretudo aos olhos daqueles que se beneficiavam daquele contexto. Seriam eles principalmente os oriundos das nações que lideravam e viviam intensamente o processo de industrialização pelo qual passava a Europa. Como líder a Inglaterra em seus anos vitorianos, a mesma onde viveu Galton.

\subsection{Criação de redes contra a "decadência biológica": as sociedades eugenistas pelo mundo}

Após os primeiros esforços teóricos, institucionais e publicistas empreendido por Galton e seus colegas, o eugenismo começa a rapidamente ganhar adeptos e tomar forma nas instituições por meio de Congressos, publicações, laboratórios de medição e pela entrada nas disciplinas curriculares. Pelas considerações emocionadas de Person feitas cercas de quatro décadas depois - publicadas no capítulo dezesseis da biografia de Galton- teria sido a partir do início do século XX que Galton, a quem atribui poderes individuais revolucionários, conseguiu angariar prosélitos para a nova "fé":

The careful reader of this work will have realised how deeply impressed Galton was by the idea that with man himself lies the possibility of improving his race; and this impression existed long before Galton initiated active propaganda for Eugenics as a social and political creed. Indeed, although Galton's earlier writings reached a limited and partly prepared audience, it was not till the beginning of the presente century that he considered the time ripe for a more general public appeal, or sought proselytes to the new faith. (PERSON, 1930, p. 28)

Na sequência Person exalta o amigo Galton pela criação e difusão daquilo que se tornou o movimento eugenista - observação, aliás, que elucida a importância adquirida pelo movimento nas primeiras décadas do século $\mathrm{XX}$ - afirmando que poucas ciências poderiam ser atribuídas - na visão singular do autor - a apenas um criador. No caso da 
eugenia, Person apresenta a exceção, o que evidencia a admiração - compartilhada por muitos - pelo amigo:

There are some creeds, and more sciences, of wich it is nearly impossible to name a single individual as the creator. When we speak of Christianity we forget, or wilfully disregard, Paul; Einstein was not the first to see material phenomena in the curvature of space; nor did Darwin stand alone when he propounded evolution through natural selection. But what student of evolution before Galton, realising the past acent of man, grasped that his future lies with himself, if he be willing to study and control his own breeding? It is given to few men to name a new branch of Science and lay down the broad lines of its development; it is the lot of fewer still to forecast its future as a creed of social conduct. In the thirty years wich have elapsed, since Galton started his public teaching, what gratifying progress has been made, not only in stablishing institutes and laboratories for research in Eugenics, but also in familiarising the people at large with the code of conduct wich na acceptance of eugenic principle evolves! (Idem)

Estes movimentos que se configuraram pelo mundo não foram homogêneos, tampouco consensuais. Se as teorias e propostas práticas eugenistas foram muito sedutoras desde o momento em que se apresentaram, é certo que houve também intensos debates e mesmo opositores.

Karl Person na supracitada biografia reúne algumas cartas entre Galton e seus arguidores que bem elucidam os principais questionamentos suscitados por suas publicações. Dentre eles, destacamos aqui o botânico franco-suiço Alphonse Louis Pierra Pyrame de Candolle (1806- 1893), estudioso da influência dos fatores ambientais no desenvolvimento dos seres vivos e a quem é atribuído o pioneirismo nos estudos ecológicos; e Gilbert Keith Chesterton (1874-1936) - conhecido como G. K. Chesterton - escritor, economista e polímata cujas incursões pela literatura e pela economia rendem reconhecimentos até a atualidade ${ }^{9}$.

\footnotetext{
${ }^{9}$ Para a preservação, discussão e difusão das obras de Chesterton há a Sociedade Chesterton Brasil, bem como outras pelo mundo que se dedicam ao pensamento do escritor: <http://www.sociedadechestertonbrasil.org/>. Acesso em out. 2015.
} 
Acerca do debate entre Galton e Candolle, sintetiza Del Cont:

A obra English men of Science: their nature and nurture (Homens ingleses de ciência: sua natureza e nutrição) foi escrita por Galton em 1874, como resposta à obra, publicada no ano anterior, de Alphonse de Candolle (1806-1893), Histoire des sciences et des savants depuis deux siècles (História das ciências e dos sábios nos dois últimos séculos), que diferentemente de Galton, defendiam que a educação e o ambiente social eram, de fato, os fatores que contribuíram fundamentalmente o desenvolvimento das capacidades cientificas ou intelectuais dos indivíduos, negando qualquer fundamento para a herança da genialidade defendida por Galton na obra de 1869 ... Em resposta, ao negar a influência da instrução, concedendo-lhe somente o papel de desenvolver capacidades que já estariam presentes desde o nascimento, Francis Galton procurava sustentar que, se não houvesse um controle da qualidade reprodutiva dos indivíduos na sociedade, o resultado em pouco tempo seria o avanço reprodutivo de indivíduos degenerados. O que significaria, em termos estatísticos, que os melhores membros da sociedade seriam suplantados reprodutivamente pelos indivíduos menos qualificados, ampliando, consequentemente, a criminalidade, a prostituição, a delinquência, a insanidade e todo tipo de distúrbio social. (DEL CONT, 2008, p. 06)

O debate entre Galton e Candolle persiste como caso exemplar para reflexões sobre a polêmica nature versus nurture, servindo como fonte para trabalhos diversos ${ }^{10}$. Se há indícios de que Candolle mudou seu posicionamento a favor de Galton com o passar do tempo, o mesmo não ocorreu com o contundente Chesterton, que argumentou brilhantemente contra os perigos da eugenia, chegando a publicar em 1922 uma obra dedicada ao anti-eugenismo chamada Eugenics and other evils. Para o escritor, o eugenismo deveria ser combatido segundo a mesma lógica da qual fazia uso, ou seja, deveria ser um mal a ser extirpado antes mesmo de sua existência. Chesterton a chamava de falsa teoria, a acusava de cinicamente ambígua, baseada em valores morais e aplicações sociais venenosas que atentavam, inclusive, contra a sensibilidade humana. Por mais que seus protagonistas se vissem como benfeitores, faziam, na prática, o mal ao considerarem a humanidade estritamente por seu valor utilitário. Pelas palavras do autor:

It is a thing that can be pointed out; it is a thing that can be discussed; and it

\footnotetext{
${ }^{10} \mathrm{O}$ artigo "Statistics and human hereditary talento. Alphonse de Candolle VS. Francis Galton", de Carlos Lópes Beltrán apresenta importantes considerações sobre o tema. Disponível em: <https://www.academia.edu/5859701/Statistics_and_Human_Hereditary_Talent._Alphonse_De_Candolle _vs_Francis_Galton>. Acesso em: out. 2015.
} 
is a thing that can still be destroyed. It is called for convenience "Eugenics; and that it ought to be destroyed I propose to prove in the pages that follow. I know that it means very diferente things to diferente people; but that is only because evil always takes advantage of ambiguity. I know it is praised with high professions of idealism and benevolence; with silver-tongued rethoric about purer motherhood and a happier posterity. (CHESTERTON, 1922, p. 1)

Sob os auspícios dos defensores e críticas pontuais, realizaram-se as iniciativas primeiras, que partiram de Galton e de seus principais interlocutores, sendo eles Julian Huxley, Walter Frank Weldon, Montagu Crackanthorpe, Karl Pearson e Charles B. Davenport, entre outros.

Como marco inicial do processo de institucionalização da eugenia tem-se a instalação de um laboratório de biometria na Exposição Internacional de 1884, realizada em Londres. Neste laboratório, o público poderia ter suas medidas tiradas e analisadas segundo os padrões estatísticos aos quais Galton havia chegado. Houve, ainda, a publicação da revista Biometrika, em 1901 - uma iniciativa de Galton, Pearson e Weldon - que se tornou um importante meio de divulgação da eugenia, pois sendo editores adeptos da teoria, constituía um local de aceitação plena de suas publicações.

Nos primeiros anos do século XX, Galton proferiu diversas conferências na Inglaterra, aumentando sua gama de interlocutores e simpatizantes da causa eugenista, como o caso do biólogo norteamericano Charles Davenport, que criou, nos Estados Unidos, uma primeira sociedade eugenista logo em 1903, após ter presenciado uma conferência de Galton. Tratava-se da Associação Americana de Reprodução, tendo o conferencista Galton como membro honorário. No ano de 1906, o Laboratório de Biometria da Universidade de Londres transforma-se no Laboratório Galton para a Eugenia Nacional. Em 1908, o mesmo organiza a reunião inaugural da Eugenics Education Society, sob presidência de seu sobrinho Leonard Darwin. Esta sociedade 
promoveu o $1^{\circ}$ Congresso Internacional de Eugenia em 1912, com 700 delegados oriundos de países diversos. A partir daí, instituiu-se um comitê permanente de eugenia, com representantes da Alemanha, Bélgica, Dinamarca, Estados Unidos, Itália e Noruega.

Pelas palavras do farmacêutico e médico brasileiro Renato Kehl:

Esse grande scientista inglez fundou em 1905 a "Eugenics Record Office", annexa á Universidade de Londres, onde se estudam os assumtos ligados á evolução humana. A sua principal e inicial preocupação foi averiguar os processos de selecção empregados pelos espartanos e adaptal-os aos tempos actuaes. Galton, depois de acurado estudo, publicou em 1909 o "Essays in Eugenics", no qual enalteceu o valor desta sciencia e estabeleceu os methodos e fins a seguir. Affirmou nesta obra a sua tendência em tornar-se cada vez mais acceita pelo publico, desfazendo-se o falso conceito de utópica, que lhe deram á primeira vista. (KEHL, 1929, p. 11)

Kehl mostra-se otimista quanto ao sucesso do movimento ao afirmar que:

\begin{abstract}
Não é mais preciso encarecer o valor da Eugenia; o numero crescente de proselytos e, sobretudo, de sociedades eugenicas espalhadas pelo mundo é bastante para demonstrar o interesse que tem despertado. Nos Estados Unidos a aceitação foi enthusiastica. Vinte e oito Universidades tiveram nos seus programmas escolares o ensino dessa sciencia. Para dar idéa da preoccupação americana a este proposito, basta dizer que, por iniciativa de Grahan Bell, 530.000 professores foram incumbidos de fornecer informações sobre o estado de 24 milhões de crianças em idade escolar, sob o ponto de vista eugênico, isto é, da aptidão individual, profissional, chegando-se á conclusões interessantes e de alto valor, no tocante á prophylaxia racial. (Idem)
\end{abstract}

Observa-se, então, uma profusão de sociedades eugenistas por países da Europa e

Estados Unidos. A $1^{\circ}$ Guerra Mundial e suas mazelas em muito contribuíram para fortalecer as convicções dos adeptos acerca da necessidade do estabelecimento pleno desta forma de ciência que se configurava. A polêmica nature versus nurture, diante de eventos funestos como a guerra, acabou por ser superada por muitos eugenistas a partir de quando passaram a crer fortemente que certos comportamentos humanos eram frutos de caracteres fixos e não de escolhas, fossem individuais, políticas ou psicossociais. Evitar certos caracteres seria a grande solução contra a decadência. A redenção, orientada 
pela biologia e pela matemática, seria capaz de fornecer, nas palavras de Person, uma nova geração de Apolos gregos:

It is as if the Great War had so thoroughly demonstrated that pitiable failure of humanity, that its thinkers and leaders felt that the old man must be replaced by a new-born Apollo, the worn-out credd wich had failed him by a more adequate faith... With our presente acquaintance with the laws of heredity, with our presente knowledge of how customs have changed, can we not hasten the evolutionary process of fitting man to the needs of his presente environment? (Ibidem)

Atentar para o desenvolvimento histórico das sociedades e instituições eugenistas torna-se importante perante a primazia do caso alemão que, por sua dimensão, por vezes acaba sendo associado à prática exclusiva da eugenia na História. Sobre isso alerta a historiadora Pietra Diwan:

\begin{abstract}
Quase três décadas após o inglês Francis Galton dedicar-se à divulgação da eugenia, a Inglaterra não se convenceu da necessidade de transformar em legislação suas ideias sobre a hereditariedade para o incremento do estoque de bem-nascidos. No entanto, "hereditarizar" os comportamentos negativos tornou-se uma norma entre biólogos para resolver todos os problemas sociais em diversos países. O eugenismo moderno origina-se dessa ideia primordial e, até a primeira metade do século XX, tratará de cooptar médicos e biólogos com opiniões políticas e filosóficas as mais variadas. Muito antes da ascenção do nazismo, a eugenia foi legalizada em países de tradição democrática. A primeira lei de esterilização, por exemplo, foi implantada nos Estados Unidos, em 1907. Centenas de milhares de esterilizações foram realizadas no mundo todo sob o argumento da melhoria da raça. Atualmente, a eugenia ainda é vista como um tema tabu pelas ciências médicas e sempre é mostrada de forma edulcorada, minimizando suas consequências e responsabilizando ora nazistas, ora o degeneracionismo pessimista e romântico de Gobineau. Na verdade, houve uma multiplicidade de facetas adotadas pelo eugenismo que particulariza cada análise de acordo com a época e o país, sob o prisma ideológico de seus defensores. Uns mais radicais que outros, o certo é que não houve um uso homogêneo da teoria de Galton. (DIWAN, 2007, p. 48)
\end{abstract}

As técnicas a serem empregadas para a regeneração humana - e sobre a necessidade desta parecida haver um consenso- dependiam da teoria adotada. Durante as primeiras décadas do século XX, no cerne do movimento o principal debate tornou-se aquele dentre as bases teóricas lamarckistas (ou neolamarckistas) e a mendelista. Em linhas gerais, a primeira vertente - dado o pressuposto lamarckista da interferência do 
meio nos caracteres hereditários - considerava a influência do meio no processo evolutivo e, portanto, na prática passou a ser relacionada com as medidas de saneamento e higienismo. Os limites restritivos caracterizavam-na como uma forma de eugenia positiva, mesmo que inicialmente o adjetivo "positiva" levasse em consideração a procriação dos mais aptos, em oposição ao adjetivo "negativa" como impedimentos aos inaptos.

Já os pressupostos mendelistas consideravam os caracteres hereditários como imutáveis, não sofrendo interferência do meio. Para os eugenistas desta convicção não seria útil, portanto, a melhora das condições de existência, mas das condições biológicas, pois a partir delas é que viria a evolução. Para tanto, fazia-se necessário impedir a proliferação dos caracteres defeituosos, o que caracterizaria uma forma de eugenia negativa. Permite-se concluir que havia uma gradação na radicalidade das medidas propostas.

Importante ressaltar que o uso dos termos "eugenia lamarckista" e "eugenia mendelista" se deve à apropriação dos respectivos modelos teóricos feita por adeptos ou analistas do eugenismo, e não pela atuação de Lamarck e Mendel no mesmo, o que seria um anacronismo.

Papel central na difusão dos ideais eugênicos foi aquele dos médicos e juristas que ao movimento aderiram. O conceito tornou-se um termo médico e sua efetivação contava com redes de representantes de profissionais da saúde variados. Dentre discussões acerca do que era ou não viável, as diferentes propostas eugenistas - imbuídas de ímpetos missionários - foram bem recebidas e renovadas no Brasil. 


\title{
Capítulo 2: Olhares: aspectos teórico-metodológicos
}

Sabemos que as metodologias das pesquisas sociais por vezes - e dependendo, sobretudo, do tipo e objeto de estudo - não correspondem às expectativas ortodoxas que concebemos como padrão científico. Tais heterodoxias podem gerar problemas, ou angústias, tanto para os próprios pesquisadores quanto para sua rede de relações profissionais.

Uma possibilidade de superação dos problemas decorrentes dessas diferenças e da inserção interdisciplinar da História - sem, no entanto, torná-la irreconhecível - é conceber a metodologia em Ciências Sociais e Humanas como o próprio estabelecimento de um tipo de lógica para a compreensão de determinada realidade. Teorias e métodos passam a ser um elemento da consciência que condiciona a leitura da realidade de uma determinada forma, funcionando como filtros que nos levam a direcionar o olhar para certas coisas em vez de outras. Esses filtros, cremos, potencializam a capacidade de compreender um dado objeto, um fenômeno ou mesmo a relação entre fenômenos:

\begin{abstract}
A escolha metodológica é, como se entende, uma questão subjetiva. Todo pesquisador ou trabalhador intelectual tem suas convicções. Estas convicções, por sua vez, constituem o pano de fundo sobre o qual se efetivam as opções por tema, problema e, consequentemente, metodologia. Por mais que o pesquisador tenha em apreço uma esfera subjetiva e uma esfera objetiva de seu trabalho, e por mais que ele deseje controlar as interferências mútuas, é apenas uma premissa remota que possa fazê-lo. Um dos poucos momentos dessa independência entre partes inseparáveis é a escolha do método de pesquisa. Existe uma objetividade no método da pesquisa, qual seja, o tipo de metodologia fica relativamente imposta pela escolha do tema e, ainda mais, a formulação do problema no tema. No entanto, a necessidade de ser objetivo, ou seja, o valor que o pesquisador atribui à objetividade leva-o a formular sua escolha de metodologia do modo mais coerente possível com o tema e o problema que nele interessa. (BARBOSA, 1992, p. 04) ${ }^{11}$
\end{abstract}

\footnotetext{
${ }^{11}$ Disponível em: <https://sites.google.com/site/dnbwilson/textosdeteoriaemetodologia>. Acesso em: out.
} 2015 
Este capítulo dedica-se, inicialmente, à acerca do status da eugenia galtoniana perante as ciências, por meio de reflexões e análise de sua própria teoria, método e técnicas; a seguir discorre sobre as principais obras teóricas e trabalhos acadêmicos que orientam as perspectivas aqui expostas sobre o movimento eugenista e sobre o pensamento do farmacêutico e médico Renato Kehl, objeto singular de análise do presente trabalho.

\subsection{Caracterizando a eugenia}

A presente reflexão parte dos aspectos da eugenia proposta por Francis Galton em sua obra Inquiries into human faculty and its development, publicada primeiramente em 1883 pela Macmillan (editora londrina fundada no ano de 1843). Para tanto, utilizamos a versão eletrônica publicada no ano de 2004, editada por Gavan Tredoux e disponível no site <www.galton.org $>$.

Propor-se à tarefa de estudar a história da eugenia é depara-se, inevitavelmente, com desafios conceituais, dadas as especificidades que este movimento social e científico possui, sendo apresentado ora como ciência - com hipóteses e leis específicas, extraídas por métodos estatísticos- ora como técnicas ou conjunto de técnicas. Se as ideias eugenistas parecem ser tão antigas quanto a humanidade, é certo que o movimento se constituiu em campo específico: configurou-se como uma forma de ciência, formou-se como disciplina a ser ministrada em todo o processo educacional (dividindo-se em temas 
eugenistas pertinentes as crianças, adolescentes e adultos), constituiu-se como fornecedora de técnicas a serviço da saúde pública e criou seus próprios eventos e publicações.

Debruçar-se sobre documentos diversos - das correspondências e artigos às obras de divulgação e manuais- relacionados ao movimento eugenista implica em enfrentar a polissemia e um emaranhado conceitual e teórico: por um lado, a eugenia -tal qual entendida por seus formuladores pioneiros- deveria oferecer, a partir de teorias e hipóteses, dados para a construção de um conhecimento específico acerca dos mecanismos de hereditariedade. Por outro, deveria cuidar de conhecimentos que orientassem a parte prática, sendo seu fim a aplicabilidade que levaria tanto à confirmação de suas propostas iniciais quanto à sua missão e razão de existir: o melhoramento das espécies. Tratava-se, portanto, de uma ciência, tal como a definiam, somada as técnicas específicas. Tal aspecto da eugenia suscita, atualmente, debates acerca de seu status perante as ciências. Apesar das concepções que regem os leitores do século XXI e, consequentemente, dos estranhamentos perante as especificidades da eugenia, é certo que o termo "ciência" - tal qual compreendido por seus formuladores durante a segunda metade do século XIX - era usado para caracterizá-la e foi este o status ao qual objetivou sua criação.

As respostas elaboradas acerca da polêmica sobre o status "ciência" ou "pseudociência" da eugenia podem ser múltiplas. Sobre isso, afirmou Renato Kehl:

Admitte-se significação diversa entre as palavras Eugenia e Eugenismo: a primeira correspondendo á sciencia que investiga, que colhe, prova e coordena factos, com elles constituindo os princípios; a segunda, correspondendo ao culto e á acção eugenica, representando, pois, a sua applicação sociológica. Torna-se dispensável esta differenciação, considerando-se a sciencia de Galton como subdividida em uma parte theorica e outra pratica. (KEHL, 1929, p. 05) 
Diante disso, cabem reflexões sobre os postulados da obra inaugural que - mesmo que não isolada e sempre relacionada ao seu contexto, às matrizes intelectuais da época e à rede de pesquisadores que se imbuíam das ideias evolucionistas e missões salvacionistas- sintetizou estes estudos e convicções diversas que possibilitaram a elaboração de tal teoria. Considera-se aqui que as obras de Galton são tanto objeto de estudo histórico como proponentes em si uma concepção de História - entendida, neste caso específico, como o desenvolvimento, progressos e decadências das sociedades humanas - regida pelas leis da hereditariedade (estas fixas, válidas para todos os seres vivos).

Inquiries into human faculty and its development apresenta na introdução seu objetivo maior: estudar as variações das faculdades e características entre diferentes indivíduos, entre diferentes famílias e raças, para entender o quanto, durante a história, provou-se que grupos humanos ineficientes foram substituídos por melhores linhagens. E assim considerar se seria ou não dever da geração atual empreender esforços para que a evolução entre os humanos se desse mais rapidamente e sem atrasos do que se fosse deixada ao ritmo de seu próprio curso.

Não obstante eventual exagero que possa ter motivado a observação acerca da importância da obra, é evidente que o conteúdo ali compilado fundamentou o extenso movimento eugenista que se desenvolveu posteriormente em diferentes espaços. Tenham sido eles pautados por suas singularidades, é certo que a base teórica e as técnicas para identificação das melhores ou piores características hereditárias que constituíram a "ciência do melhoramento da espécie" estavam lançadas. Seguem-se os principais postulados. 


\subsubsection{Variabilidade e diferenciações humanas}

Galton alinhava-se com as ideias evolucionistas de seu primo Darwin e demais $\operatorname{colegas}^{12}$ ao afirmar que o mundo vivo não consiste em uma repetição de elementos semelhantes, mas sim em uma variedade interminável de características. A prevalência ou desaparecimentos destas características se daria pela ação da seleção adaptativa. Uma característica útil para determinado espaço e tempo poderia não ser útil para outros.

A partir desta noção de variabilidade e diferenciação entre espécies e entre os seres de uma mesma espécie, admitia que:

- a riqueza intelectual e moral de uma nação seria resultado da variação multifatorial dos talentos daqueles que a compunham, sendo o oposto do melhoramento considerar todos os membros de uma nação como pertencentes ao mesmo tipo.

- em todas as raças de animais domesticados, como os humanos - estes com a particularidade de sofrerem mudanças mais rapidamente- há elementos de pouco ou sem nenhum valor, potencialmente danosos para a sociedade, seja por questões ancestrais ou por serem resultados de degenerações. Haveria possibilidade de erro neste julgamento, fazendo com que mais tarde algumas dessas características consideradas danosas se demonstrassem boas para o bem público. Mas estes erros seriam poucos e, se cometidos com o intuito do melhoramento da espécie, seriam justificáveis.

\footnotetext{
${ }^{12}$ As teorias evolucionistas foram elaboradas por diversos autores, não se tratando de uma única obra autoral. O próprio Charles Darwin, autor sobre o qual quase todo o mérito recaiu, observou a existência de cerca de 20 estudiosos que, antes dele, dissertaram sobre a transmutação das espécies ao longo do tempo.
} 
- características morais inatas, faculdades intelectuais e físicas estariam fortemente ligadas umas às outras.

Galton acreditava que a vastidão de variações presentes na espécie humana - que afirmava serem por vezes tão sutis quanto numerosas- derivava de traços comuns, daquela que seria a fisiognomia representativa de uma raça.

Estas variações não seriam, no entanto, isentas de significado, já que estariam relacionadas com características morais e intelectuais. A fim de auxiliar na procura por essas faces realmente representativas, o terceiro capítulo de sua obra é dedicado a explicação do método chamado composite portraiture - retratos compostos, em tradução livre. Tais seriam os princípios e passos do método:

I) Coleta de fotos de diferentes pessoas a partir de ângulos iguais, bem como de mesma condição de luz e sombra (por exemplo, com a luz vindo do lado direito);

II) Redução dos retratos ao mesmo tamanho, usando escalas a partir de pontos referenciais;

III) Superposição dos retratos (como folhas de um livro), ordenando partes de um rosto com as respectivas do outro rosto (por exemplo: olhos com olhos, bocas com boca). Após o devido ajuste, com auxílio da luz, duas bordas das páginas eram grudadas, tornando-se como um livro;

IV) Prendia o livro contra a parede de modo que pudesse mover as páginas e observar os rostos completamente

V) Focava firmemente uma câmera no livro, com uma chapa fotossensível dentro dela. 
VI) Começava a fotografar todas as páginas, sem mover a câmera, de modo que todas as fotos dos retratos fossem gravadas na mesma parte da chapa.

Este método teria sofrido algumas modificações no futuro, mas com o mesmo objetivo de possibilitar o encontro de uma única figura a partir de várias outras. Permitiase, assim, concluir qual seria o rosto "comum" entre os homens eminentes, de notáveis talentos, bem como quais seriam os traços típicos dos criminosos, por exemplo. 


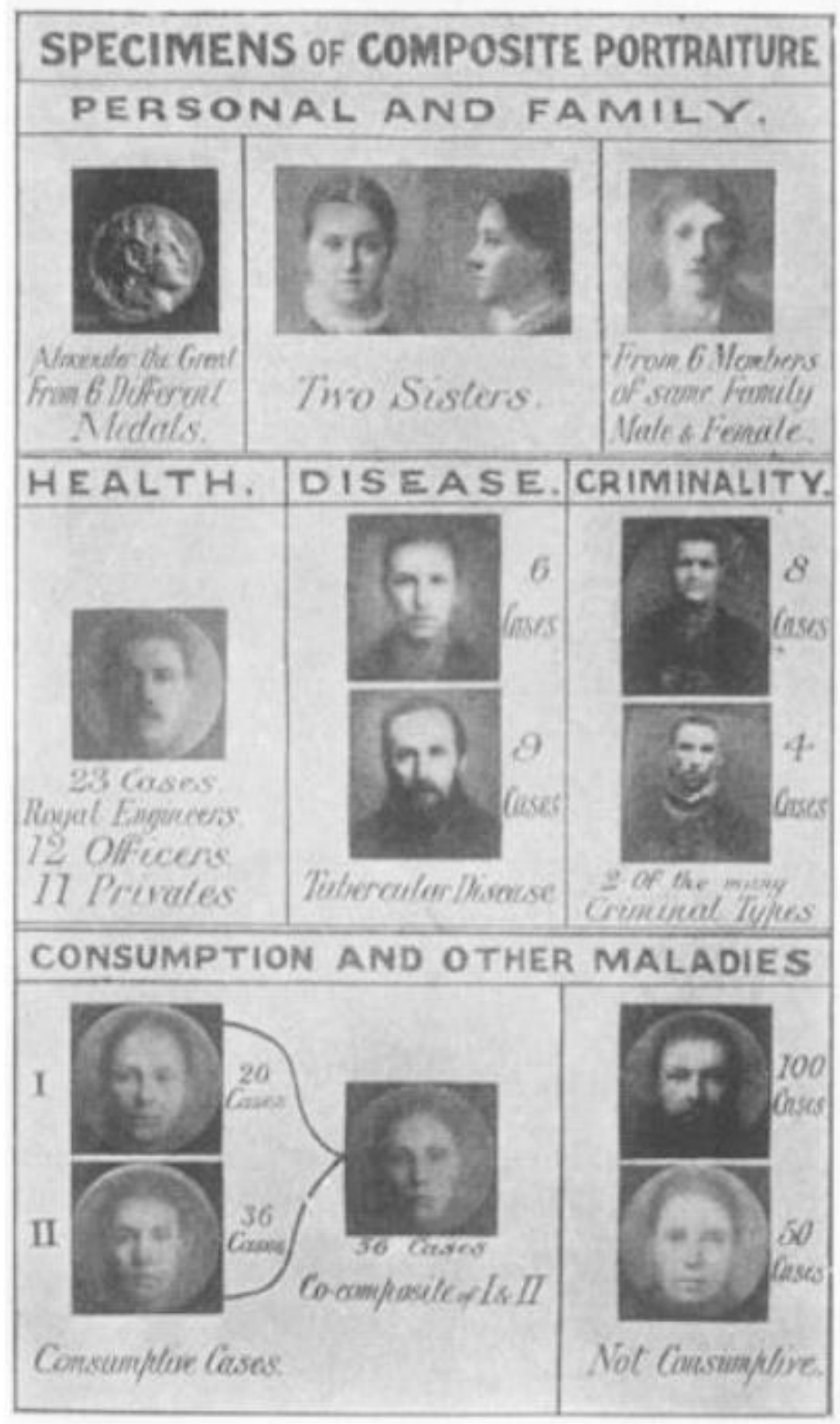

Figura 1. Figura 1. Esboço esquemático dos retratos compostos. Fonte: Galton, 1883, p. 08.

Dentre os objetos de seu estudo, estavam a fisionomia do Alexandre, o Grande, tais quais representadas historicamente, membros de famílias aristocráticas, membros de famílias vitimadas pela tuberculose ou tipos criminosos.

Para encontrar os traços pertinentes à saúde, afirma ter combinado os retratos de doze 
oficiais da Royal Engineers, tirados especialmente para ele por aquele que chama de Lieutenant Darwin (patente equivalente ao tenente, provavelmente de um parente próximo). Afirma Galton que havia traços em comum nos retratos dos oficiais, mesmo sendo oriundos de lugares diferentes da Inglaterra. Para além dos traços em comum, as qualificações corporais e mentais requeridas no processo seletivos forneceriam dados demonstrativos das semelhanças físicas e aptidões mentais, fundamentando as correlações que fundamentavam a conclusão de que aqueles eram, portanto, os traços típicos dos portadores de boa saúde.

O mesmo método teria sido aplicado para a análise de duas categorias de penitenciários, comprovando, para Galton, a veracidade da correlação. Abastecido com fotos de identificação fornecidas por Sir Edmund du Cane, diretor de prisões, afirma ter encontrado traços distintivos entre os prisioneiros naquilo que seria "a mais triste desfiguração da civilização moderna". Prossegue afirmando que seria dificultoso e faziase necessário esforço de superação para prosseguir com a classificação dos criminosos, dada a aversão causada por seus rostos. Finaliza sua explanação sobre o método confessando o desejo de que fotógrafos amadores passassem a levar a tarefa de fotografar e classificar as variadas raças humanas seriamente. Não apenas por questões de curiosidade, mas por sua utilidade.

Sobre os métodos de definição de caracteres desejados versus os indesejados Stephen Jay Gould chama a atenção para uma publicação de Francis Galton em 1909:

Sempre que tenho a oportunidade de classificar as pessoas que encontro em três classes distintas 'boa, regular e ruim', utilizo uma agulha montada como se fosse uma pua, com que perfuro, sem ser visto, um pedaço de papel cortado toscamente em forma de cruz alongada. No extremo superior, marco os valores "bons", nos braços os valores "regulares", e na extremidade inferior os valores ruins. As perfurações são bastante distanciadas para permitir uma leitura fácil no momento desejado. Escrevo em cada papel o nome do sujeito, o lugar e a data. Com este método, registrei minhas observações sobre a beleza, classificando as moças que encontrei como atraentes, indiferentes ou 
repelentes. É claro que esta foi uma avaliação puramente individual mas, a julgar pela coincidência dos diferentes intentos realizados com a mesma população, posso afirmar que os resultados são consistentes. Assim, comprovei que Londres ocupa a posição mais elevada na escala da beleza, e Aberdeen a mais baixa. (GALTON, 1909, citado por Gould, 1999, p. 67)

Quesito importante para avaliar uma nação seria a medição das qualidades corporais de seus indivíduos. No item que dedica a este tema Galton lamenta a falta de dados antropométricos sobre os ingleses do passado para que se estabeleçam estudos comparativos que permitiram concluir se a população inglesa estaria melhorando ou deteriorando. No entanto, pelos dados disponíveis, já seria possível afirmar e se preocupar com o fato de que a população urbana da Inglaterra estaria se deteriorando. Uma prova disso seria a diminuição da altura. Se a média de estatura dos jovens era menor do que a dos mais velhos, certo estava que o processo evolutivo estava sendo revertido.

Era evidente, no entanto, que este processo estava restrito a massa urbana, já que aqueles que moravam em melhores condições e se alimentavam melhor demonstravam, ao contrário, evoluir.

Bons exemplos que confirmavam este postulado que relacionava altura com evolução seriam a superioridade dos atletas de sua época - neste caso, da segunda metade do século XIX - perante os do início do século, bem um exemplo elucidativo deria o caso do próprio Galton, que afirma ter sido mais alto que a maioria dos seus colegas do Trinity College, em Cambridge, durante os anos de 1880-1884. Sua estatura seria superior principalmente à média dos que conquistavam apenas notas baixas. Posteriormente, ao revisitar a escola, Galton notou que se encontrava abaixo da média daquela multidão de "pessoas bem vestidas", já que não se sentia mais capaz de enxergar para além das cabeças, como fazia antes. 
Outra evidência que confirmaria a evolução entre os estudantes do Trinity College e estes considerados caso exemplar da evolução entre os eminentes- seria, novamente, a superioridade do desempenho atlético comparado ao do passado. Assume que parte desta evolução poderia ser atribuída ao emprego de melhores técnicas e métodos de treinamento, mas atribui a maior parte da explicação ao fato das mulheres - que seriam mães destes jovens - terem levado uma vida mais regrada e saudável, influenciando positivamente na geração de uma parcela favorecida da raça. Tal observação permite concluir que seus estudos partiam do pressuposto da existência de caracteres que se mantinham ao longo das gerações bem como de caracteres que poderiam ser adquiridos e repassados a partir da alimentação e da boa conduta.

Avistar estes melhoramentos, porém, não seria suficiente para considerar a nação fora do perigo da degeneração e decadência. Afinal, os piores casos de degeneração e fraqueza estariam fora de nossas vistas, confinados em casas, hospitais, asilos e prisões. Estes casos - em sua opinião, os mais tristes e piores- seriam causados por imperfeições congênitas que vitimariam mesmo aqueles de "valor".

Neste sentido, a eugenia se reverencia como uma técnica a serviço do bem comum, proporcionando dados e orientando intervenções para evitar a existência de doentes, para além de outros campos que forneciam dados e técnicas em busca de curas ou melhora da qualidade de vida em si.

\subsubsection{Eugenia como ciência aplicada}

Consideramos, assim, que a eugenia galtoniana apresentou-se como um conjunto de técnicas e métodos de investigação e, posteriormente, de aplicação - como no caso dos 
projetos de restrições matrimoniais e esterilização elaborados por sociedades eugenistas - derivados de uma interpretação muito específica do mundo e da história da humanidade, o que a caracterizaria como ciência aplicada. Sua teoria principal seria a de que a variabilidade humana era condicionada positivamente ou negativamente pelos caracteres hereditários, expressos em características físicas, mentais e morais que apresentavam correlação.

O problema da indução torna-se importante para analisar o desenvolvimento teórico da eugenia galtoniana, já que se configurou em um contexto específico - pessoal, social e intelectual - onde as generalizações a partir dos postulados faziam-se pertinentes. Assim, era plausível que os métodos estatísticos propostos por Galton a partir de observações corriqueiras e cotidianas servissem de lastro para a sua teoria. Tomando como exemplo a questão da estatura elevada vinculada a probidade física e intelectual, suas formulações comprovam-se como teoria ao serem passíveis de falseamento, tal qual proposto pelo filósofo Karl Popper na obra A Lógica da Pesquisa Científica, publicada em 1933. Tais teorias que correlacionavam características físicas e intelectuais como comprobatórias da superioridade evolucionista seriam, assim, facilmente falseáveis ao se demonstram um humano de menor estatura que superasse outro de maior estatura em um mesmo teste de aptidão mental, por exemplo. $\mathrm{Ou}$, de maneira ainda mais contundente, se um ser humano portador de condição congênita demonstrasse maior força ou habilidade matemática do que um dos chamados "homens eminentes", de altura, status social, riqueza e inteligência superiores. O próprio autor da teoria, eventualmente chamou a atenção para as chamadas exceções, bem como atentava para os cuidados necessários com generalizações. No entanto, suas observações laboratoriais e cotidianas pareciam, inevitavelmente, confirmar sua teoria.

Nota-se que seus ímpetos investigativos não tinham fins meramente classificatórios e 
baseavam-se a priori na existência da hierarquia entre humanos decorrentes da variabilidade de seus caracteres e sob influência da seleção adaptativa. Orientada, portanto, pelo paradigma evolucionista da hereditariedade, seus métodos e aplicações partiam de problemas e perguntas vinculadas ao pensamento dicotômico que pressupunha a existência de caracteres biológicos condicionantes do progresso versus decadência humanos. Uma pergunta que, por pouco questionada em si, tornou-se insistente e inevitavelmente produziu respostas duvidosas que perduram até a atualidade.

\subsection{Como se escreve a História? "Nem fatos, nem geometral, mas tramas"}

Dentre as obras diversas que orientam esta pesquisa, destacamos aquelas que orientaram os olhares para as fontes históricas e contribuíram para os caminhos interpretativos.

Primeiramente, vale deter-se nos ensinamentos do historiador francês Paul Veyne compilados em Como se escreve a história, obra publicada no ano de 1971 que trata - em tom pouco usual - dos principais dilemas da história, sobretudo como campo de estudo, mas também como noção/conceito. A pergunta que inaugura o livro é conhecida: "o que é a história?" A fim de problematizá-la e respondê-la surgem, como corolário, novas questões: “quais os objetos da história?" e “é possível uma história científica?" As elucidações se desenvolvem de maneira objetiva e contundente. Ao optar pela argumentação direta, elaborada no formato de perguntas e respostas, rica em exemplos, Veyne posiciona-se, sem receios, à margem de parte significativa da razão histórica ocidental. 
"Nem fatos, nem geometral, mas tramas" é o capítulo terceiro do livro, que pretende, como indicam os termos que compõe o título, fornecer uma das respostas para as questões inicialmente levantadas. Partindo do pressuposto, previamente desenvolvido, de que "tudo o que aconteceu é igualmente digno da história" (Veyne, 1971, p. 41) sendo os objetos de estudo da história inteiramente dependentes da existência de documentos, seguido pela liberdade de escolha do historiador - o capítulo esclarece a razão pela qual essa suposta infinidade de possibilidades não gera o caos. Essencialmente, todo fato histórico, estudado a partir de seus vestígios, possui uma organização natural. A maneira escolhida pelo historiador para conhecer e narrar essa organização também impediria o caos, sendo que é feita a partir do raciocínio objetivo.

Ao admitir que a história seja feita a partir de escolhas e recortes, admite-se também que, sendo escolha, estas partem de uma perspectiva, dentre tantas outras possíveis. Essa perspectiva produz, portanto, uma história específica de um objeto específico que despertou interesse no historiador. Não há, portanto, possibilidade de uma história que seja plena e total, por mais largo ou estreito que seja o recorte. A metáfora deve recorrer não à imagem do geometral - uma figura retratada tal como deveria ser, seguindo as dimensões exatas do objeto, sem o uso de perspectivas - devendo, portanto, ser substituída pela imagem do cubo e suas perspectivas diversas.

As perspectivas - e seus desdobramentos - produzem uma certa história, a "história de alguma coisa"; não a história de um fato social em sua plenitude. Na construção dessa determinada história pressupõe-se, ainda, que os documentos tenham importâncias relativas: um documento x ou y poderá ser primordial para o estudo de certo aspecto de um fato, poderá, ainda, ser secundário ou totalmente descartado, de acordo com a pergunta que se faz e com o tipo de resposta que se pretende obter. 
Cabe ao historiador competente definir a pertinência dos documentos existentes, debruçando-se sobre os mesmos e sobre os eventos que estão a eles relacionados. O empenho analítico deve visar o conhecimento objetivo de suas ligações:

Os fatos não existem isoladamente, mas têm ligações objetivas; a escolha de um assunto de história é livre, porém, dentro desse assunto escolhido, os fatos e suas ligações são o que são e nada poderá mudá-los; a verdade histórica não é nem relativa, nem inacessível como uma extraordinária extrapolação de todos os pontos de vista, como um geometral (Idem, p. 42).

A ponte de acesso entre o esforço do historiador e seu objetivo - sendo este uma verdade histórica, mesmo que parcial - seria a consciência de que a história acontece por meio de tramas e que seu trabalho será "uma fatia da vida que o historiador isolou segundo sua conveniência, em que os fatos têm seus laços objetivos e sua importância relativa" (Ibidem). Os laços objetivos formariam a trama, tal qual em um romance, que necessita de ligações internas para se fazer compreender. A associação com o romance apresenta outra vantagem: relembrar os historiadores de que a história é, sobretudo, um movimento humano sujeito a dramas e acasos, o que se opõe a pretensos determinismos. Utilizando o exemplo da expedição do telegrama de Ems por Bismarck, Veyne explica que se a história, ao tratar do que foi vivido, se ativesse aos determinismos e aos fatos totais, o episódio teria que iniciar pela narração dos processos biológicos que trouxeram Bismarck ao mundo, passando pelo funcionamento do telégrafo, até chegar à polêmica decisão. Uma das dificuldades do ofício de historiador reside - uma vez tomada a consciência das dimensões da história - na escolha das tramas mais pertinentes para seus objetivos: "como no teatro, é impossível mostrar tudo, não porque isso ocuparia muitas páginas, mas porque não existem nem fato histórico elementar nem partículas factuais” (Ibidem).

A dimensão da história proposta não faz, porém, que a natureza de seu conhecimento caia em um relativismo absoluto. Veyne apóia-se em F. Von Hayck para 
afirmar que a objetividade analítica perante o terreno factual existe e impede que a história seja tomada pela subjetividade extrema ao encarar o objeto (objetivo), que a tornaria renovável e passível de interpretações quanto fossem os homens interessados em contála. Historiadores diferentes podem, se não devem, discutir objetivamente determinados fatos e suas ligações, chegando a conclusões consensuais, porque satisfatórias.

Não haveria, na História, acontecimentos totais ou caminhos exclusivamente verdadeiros: mira-se o campo factual e traçam-se itinerários para reconstruírem tramas possíveis. Para tanto, o exemplo da Guerra de 1914 é pertinente. É possível, talvez para um historiador da arte, estudar as pinturas do período, ou mesmo concluir que durante os anos que durou não foi produzido nada significativo. É possível, ainda, para um historiador interessado em questões de gênero estudar a mudança na situação das mulheres que ocorreram durantes aqueles anos. Seja pelo citado, seja pela história militar ou diplomática, Veyne afirma que a Guerra de 1914 pode assumir importâncias variadas. As testemunhas e documentos fornecerão elementos diversos para o historiador, que terá liberdade de separar os mais convenientes para seu traçado.

Tanto a história estritamente factual e política, quanto o subjetivismo puro são considerados, pelo autor, como entendimentos pobres que perduraram na razão histórica ocidental. A provocação é elucidativa:

\footnotetext{
A história não-factual foi uma espécie de telescópio que, mostrando no céu milhões de estrelas além daquelas que os astrônomos antigos conheciam, nos faria compreender que nossa decomposição do céu estrelado, em constelação, era subjetiva. (Veyne, 1971, p. 46)
}

A história objetiva e parcial, orientada por questões contextuais e pessoais é, em resumo, a defendida por Veyne. Ao recusar a "História", faz nova provocação, afirmando 
que esta só seria conhecida por Deus, cuja existência é duvidosa. Tampouco o termo "ponto de vista" é aceito, sendo que pressupõe a possibilidade de um acontecimento total, inacessível para os mortais, que só podem conhecê-lo a partir de seus pontos de vista limitados.

O mundo sublunar, termo caro ao autor, não comportaria certas utopias nascidas a partir desses desentendimentos da razão histórica. Se por séculos se pensou que há uma história geral, que o objeto da história é renovável ad eternum e que suas conclusões são tão profundas quanto o mundo, por séculos teriam perdurado três utopias. A concepção parcial pretende-se, dessa maneira, de maior pertinência para a história do vivido no mundo sublunar que, se não apresenta profundezas obscuras como a história faz crer, ao menos é interessante.

Também as teorias do discurso de Michel Foucault, expostas em suas obras e compiladas no livro A Ordem do discurso (1970) serviram como base teóricometodológica. As obras eugenistas são, assim, tratadas como instrumentos onde os autores projetaram suas ideias e construíram representações e campos relacionais diversos. A análise crítica busca tanto a análise das interdições que os discursos diversos sofrem, bem como as que os mesmos - ao se pretenderem como verdades autoritárias corroboram. Todo discurso, segundo Foucault, apresentaria em seu cerne uma estrutura de poder. O fenômeno discursivo apresenta-se ao mesmo tempo como vítima e instrumento dos mecanismos de exclusão diversos. Dentre as interdições sofridas pelos discursos, estaria em posição primordial à vontade de verdade, termo usado para designar aqueles elementos dos discursos que tem como essência e enunciado (conscientemente ou não) a transmissão de uma verdade última e legítima, baseada em argumentos previamente caros a sociedade na qual foi produzido. Os discursos científicos, sobretudo a partir do século XIX, seriam grandes arautos dessa vontade de verdade que, com apoio 
institucional, tornaram-se instrumentos de intolerância e exclusão.

As obras de Michel Foucault fornecem outras importantes orientações para o estudo dos movimentos eugenistas, sendo estas expressas nos conceitos de biopoder e biopolítica (originalmente, bio-pouvoir e biopolitique). Foucault, ao tratar do nascimento da Biologia durante o século XIX atentou para a configuração de um aspecto racista nesta área do conhecimento, centrado sempre na concepção de degeneração. É neste processo que se insere o biopoder, consistindo na estatização da vida, que passa a ser, sobretudo, biológica, regulada por mecanismos, técnicas e tecnologias do poder. Esta "anátomopolitica do corpo humano" seria regulamentada através de mecanismos racionais praticados pelo Estado, expressos em técnicas de governamentalidade que consistiriam na biopolítica. Saúde, higiene, natalidade, longevidade e raça, dentre outros, passam a ser - mesmo que não reduzidos a esta condição - instrumentos da biopolítica. As utopias eugenistas consistiram na expressão mais radical destes mecanismos (CASTRO, 2009, p. $57-60)$.

Pautamo-nos principalmente pelas definições expressas por Foucault em sua História da Sexualidade I: A vontade de saber, publicado em 1976. Neste importante trabalho definiu Foucault o biopoder e a biopolítica como sendo:

Concretamente, esse poder sobre a vida desenvolveu-se a partir do século XVII, em duas formas principais; que não são antitéticas e constituem, ao contrário, dois pólos de desenvolvimento interligados por todo um feixe intermediário de relações. Um dos pólos, o primeiro a ser formado, ao que parece, centrou-se no corpo como máquina; no seu adestramento, na ampliação de suas aptidões, na extorsão de suas forças, no crescimento paralelo de sua utilidade e docilidade, na sua integração em sistemas de controle eficazes e econômicos- tudo isso assegurado por procedimentos de poder que caracterizam as disciplinas: anátomo-política do corpo humano. $\mathrm{O}$ segundo, que se formou um pouco mais tarde, por volta da metade do século XVIII, centrou-se no corpo-espécie, no corpo transpassado pela mecânica do ser vivo e como suporte dos processos biológicos; a proliferação, os nascimentos e a mortalidade, o nível de saúde, a duração da vida, a longevidade, com todas as condições que podem fazê-los variar; tais processos são assumidos mediante toda uma série de intervenções e controles reguladores: uma bio-política da população. As disciplinas do corpo e a regulação da população constituem os 
Orientada pelo conceito de tradução de interesses do filósofo Bruno Latour, a pesquisa analisará as relações entre os interesses de Renato Kehl, enquanto cientista de seu tempo, e os interesses políticos em jogo, tanto os pessoais quanto os do contexto em que se insere sua produção. Identificar as matrizes de seu conhecimento e suas atividades enquanto cientista, relacionando-as com os interesses políticos e com seu círculo de relacionamentos é essencial para que tanto o formato de sua produção científica - nesse caso a eugenia - quanto seu impacto na sociedade sejam compreendidos de forma abrangente. Nas palavras de Bruno Latour, seria a

\footnotetext{
Tradução dos termos políticos em termos científicos e vice-versa"13. O autor ainda fornece orientações, acatadas neste projeto, para a pesquisa histórica: "eis cinco horizontes que permitem bastante bem enquadrar o trabalho do historiador: os intrumentos, os colegas, os aliados, o público e, por fim, aquilo a que eu chamaria as ligações ou os elos. (LATOUR, 1996, p.136)
}

Como terceira orientação teórico-metodológica, a obra Mitos, Emblemas e Sinais: morfologia e história (1986) - de autoria do historiador italiano Carlo Ginzburg - fornece elementos no capítulo "Sinais: raízes de um paradigma indiciário", no qual explora algumas homologias até então invisíveis aos olhares historiográficos. Para tanto, faz uso dos métodos da morfologia, que permitem a identificação de relações elucidativas entre elementos que à primeira vista parecem tão distantes, por vezes mesmo antagônicos, tais quais aqueles da História e da Medicina.

O paradigma indiciário consiste em abordagem específica para a compreensão da História, da Filologia e da Medicina, por exemplo, apresentando-as como formas de 
conhecimento científico do individual. Partindo da identificação de um traço em comum entre a proposta do médico e historiador da arte Giovanni Morelli, da psicanálise de Freud e dos métodos investigativos de Sherlock Holmes - os três contemporâneos de Kehl para concluir que os três compartilham, essencialmente, de um método interpretativo centrado sobre os "resíduos", ou seja, sobre os dados marginais e triviais que revelam singularidade dos sujeitos que os produziram. Nestas singularidades residiriam os objetos dos quais se ocupam, por exemplo, a História e a Medicina. Em seu importante texto, Ginzburg cita como exemplo do conhecimento do singular o método de impressões digitais desenvolvido por Galton, situando-o no contexto de desenvolvimento de um projeto geral de controle sobre a sociedade (GINZBURG, 1986, p. 174). Estes estudos seriam cientificamente orientados, mesmo que não passíveis de repetição. No caso específico da Medicina, afirma:

\begin{abstract}
O tom apesar de tudo defensivo de certas passagens do "corpus" hipocrático dá a entender que, já no século V a.C., começara a manifestar-se a polêmica, destinada a durar até nossos dias, contra a incerteza da Medicina. Tal persistência se explica pelo fato de que as relações entre o médico e o pacientecaracterizadas pela impossibilidade, para o segundo, de controlar o saber e o poder detidos pelo primeiro- não mudaram muito desde o tempo de Hipócrates. Mudaram, pelo contrário, durante quase 2500 anos, os termos da polêmica, a par com as profundas transformações sofridas pelas noções de 'rigor' e 'ciência'. Como é óbvio, a cesura decisiva nesse sentido é constituída pelo aparecimento de um paradigma científico centrado na física galileana, mas que se revelou mais duradouro do que ela. (GINZBURG, 1986, p. 156)
\end{abstract}

O paradigma teorizado pelo historiador é de inegável pertinência em dois níveis: tê-lo como orientação elucida os métodos e instrumentos laboratoriais utilizados pelas instituições eugenistas, estudo este essencial para o conhecimento do movimento per se; paralelamente, enriquece e ao mesmo tempo supera a polêmica entre racionalismo e irracionalismo - que intriga especialmente estudiosos da eugenia, dada sua aparente promiscuidade discursiva e os conhecidos resultados catastróficos causados sob sua 
égide.

Para o tratamento da dicotomia entre as ideias de progresso e decadência, pautamo-nos pela obra A idéia de decadência na História Ocidental (1999), de Arthur Herman. Nessa reconstrução histórica - permeada por reflexões filosóficas - afirma o historiador que, assim como a virtude, a ideia de decadência ${ }^{14}$ é uma construção histórica e, por assim ser, está sujeita às vicissitudes dos tempos e espaços nos quais se edificou. Herman historiciza os mitos decadentistas e os contrapõem aos mitos do progresso, estes últimos, segundo o autor, já devidamente desmistificados pela historiografia. Dentre os principais tipos de pessimismos identificados - estando todos inseridos em três principais categorias, sendo elas o pessimismo histórico, cultural e racial-, a crença na degeneração biológica que arrebatou as nações europeias no final do século XIX figura em papel de destaque.

Pode-se afirmar que a recepção do movimento eugenista foi calorosa por parte de alguns setores da intelectualidade brasileira do início do século XX. Compreender essa recepção, os campos propícios e os múltiplos desdobramentos do eugenismo brasileiro é tarefa complexa, já encarada por estudos que, sobretudo a partir da década de 1980, vêm constituindo importante historiografia sobre o tema. Nesta pesquisa guiamo-nos,

\footnotetext{
${ }^{14}$ Ainda sobre a ideia de decadência, há importantes contribuições do historiador Jacques Le Goff. Definindo a decadência como "um conceito confuso", o autor chama a atenção para os cuidados necessários ao se incorporar o termo à História. Após breve reconstrução arqueológica do termo, atenta: "Finalmente, a última confusão - mas não a menos grave- é a tendência dos que utilizam este conceito para misturar as ideias e mentalidades históricas do passado com a análise 'objetiva' dos períodos a que foi aplicado o próprio conceito ou, inversamente, a tendência para considerar uma só destas duas perspectivas, o que leva a fazer uma história das ideias e das mentalidades isolada do sistema global no interior do qual o conceito funcionava ou mutilando a história da consciência que dela tinham os homens do passado." In: LE GOFF, Jacques. História e Memória. Campinas, SP: Editora da Unicamp, 2003. p. 377.
} 
principalmente, pelos trabalhos de Thomas Skidmore ${ }^{15}$, Marisa Correa ${ }^{16}$, Nancy Stepan ${ }^{17}$, Lilia Moritz Schwarcz ${ }^{18}$, Vera Regina Beltrão Marques $^{19}$, Regina Cândido Ellero Gualtieri $^{20}$, André Mota ${ }^{21}$ e Luís Ferla ${ }^{22}$ para a compreensão dos múltiplos aspectos sociais, políticos e institucionais do Brasil que recepcionou e construiu seus próprios movimentos eugenistas.

Adiante, percorreremos parte da historiografia específica sobre aspectos da trajetória e das obras de Renato Kehl, sobre os quais importantes estudos tem sido publicados, sobretudo, a partir do final da década de 1990, em progressão significativa nos dias atuais, provavelmente por conta da persistência das ideias eugenistas. Para tanto, pautamo-nos, principalmente, pelos estudos de Pietra Diwan, Vanderlei Sebastião de Souza, Marcos Nalli e Carolina Kinoshita.

A trajetória e o pensamento expressos em seus escritos diversos fornecem, assim, elementos elucidativos para a compreensão de aspectos importantes da primeira década do século XX no Brasil. Por essa profusão de atividades, relações, riqueza bibliográfica e complexidade discursiva esta pesquisa se deteve sobre o seu pensamento, bem como em algumas das faces de sua vida profissional: do intelectual - herdeiro da escola de

\footnotetext{
${ }^{15}$ Thomas Elliot Skidmore, historiador estadunidense especializado em temas brasileiros. Diretor do Centro para Estudos Latino-Americanos e professor de História Moderna Latino-Americana e Estudos Brasileiros e Portugueses da Universidade de Brown.

${ }^{16}$ Mariza Corrêa, jornalista e antropóloga, ex- professora da Unicamp, tendo atuado como presidente da ABA (Associação Brasileira de Antropologia). Atualmente é pesquisadora do Pagu- Núcleo de Estudos de Gênero.

${ }^{17}$ Nancy Leys Stepan, historiadora estadunidense, professora de História das Ciências e da Medicina da Universidade de Columbia (EUA). Dedicou-se ao estudo das ciências no Brasil nos séculos XIX e XX.

${ }^{18}$ Lilia Katri Moritz Schwarcz, historiadora e antropóloga, atualmente professora de Antropologia Social da USP.

${ }^{19}$ Vera Regina Beltrão Marques, farmacêutica com especialização em Saúde Pública, Mestre em Educação e Doutora em História pela Unicamp. Atuou como professora da Universidade Federal do Paraná.

${ }^{20}$ Regina Cândido Ellero Gualtieri, cientista social, é professora de Pedagogia da Universidade Federal de São Paulo, onde pesquisa principalmente sobre temas da história da educação, das ciências e das instituições.

${ }^{21}$ André Mota, historiador, possui mestrado e doutorado pelo Departamento de História, atualmente professor do Departamento de Medicina Preventiva da USP, onde também coordena o Museu Histórico.

${ }^{22}$ Luís Antônio Coelho Ferla, historiador, possui doutorado pela USP e atualmente é professor do Departamento de História da Universidade Federal de São Paulo.
} 
pensamento positivista - ao militante que pensava sobre uma nova maneira de conduzir o mundo, do médico publicista ao médico educador, do médico que atuou na prática clínica - no contexto da medicina liberal - ao médico que proclamava com ardor as virtudes da missão eugenista. Sua trajetória relaciona-se, também com mudanças corporativas que compõem a história das práticas médicas no Brasil durante as primeiras décadas do século XX, com ênfase para o processo de medicalização da epidemiologia e da saúde pública por meio de ações centralizadoras, pautadas na luta contra a decadência e num específico modo de ascender ao "reino da saúde".

Pautamo-nos pelo constante movimento entre o que nos parece singular, expressos em seus aspectos biográficos, ao que parece próprio da sua forma de pensar ao que reproduz aquilo que era fruto de contexto, de seu campo de trabalho, do seu espaço, enfim, do ethos e pathos de seu tempo. Complementando os supracitados estudos historiográficos, pretendemos aqui reconhecimentos e novas contribuições. 


\section{Capítulo 3: O farmacêutico e médico Renato Kehl: reconhecimentos biográficos, bibliográficos e institucionais.}

\subsection{A Bíblia da Saúde}

No ano de 1926 o farmacêutico e médico Renato Ferraz Kehl (1889- 1974) publicou a obra Bíblia da Saúde (Hygiene), destinada a levar aquilo que considerava o mais elevado tipo de ciência ao alcance daqueles de "hereditariedade sã". Estes, como afirma logo no prefácio, se beneficiariam sobremaneira caso se submetessem aos recados profiláticos, suplementos vitamínicos - pilulares - e dicas de moralidade e beleza recomendados na vasta obra. O título escolhido por si só elucida os propósitos do volume: uma obra concebida para um público amplo, de caráter didático e de objetivos profiláticos, reformadores, grandiosos.

Esta preocupação demonstrada com a saúde e longevidade individual teria, como aponta no prefácio, uma missão ainda mais ampla: a melhoria progressiva da espécie humana. Fosse para o presente ou para o porvir, afirma:

\footnotetext{
... faz-se necessario que se propague a affirmação carteziana de que á medicina é que cumpre pedir a solução dos problemas que mais interessam á grandeza e á felicidade dos habitantes deste planeta... porque só ella, pela hygiene, o mais belo florão da sua coroa, pode promover o bem-estar physico e moral, a evolução melhorista da atividade somática e intelectual da humanidade. (KEHL, 1926, p.11)
}

A "evolução melhorista" deveria, portanto, ser orientada pela Medicina- em sentido amplo- e mais especificamente pela tríade formada pela "higiene, medicina social e eugenia". Esta tríade, afirma Kehl com sua típica habilidade de literato, deveria estampar, com letras de ouro, um pedestal sob a estátua da deusa Hígia, saudando a humanidade como destinadoras de um “róseo porvir”, garantido pela saúde. 


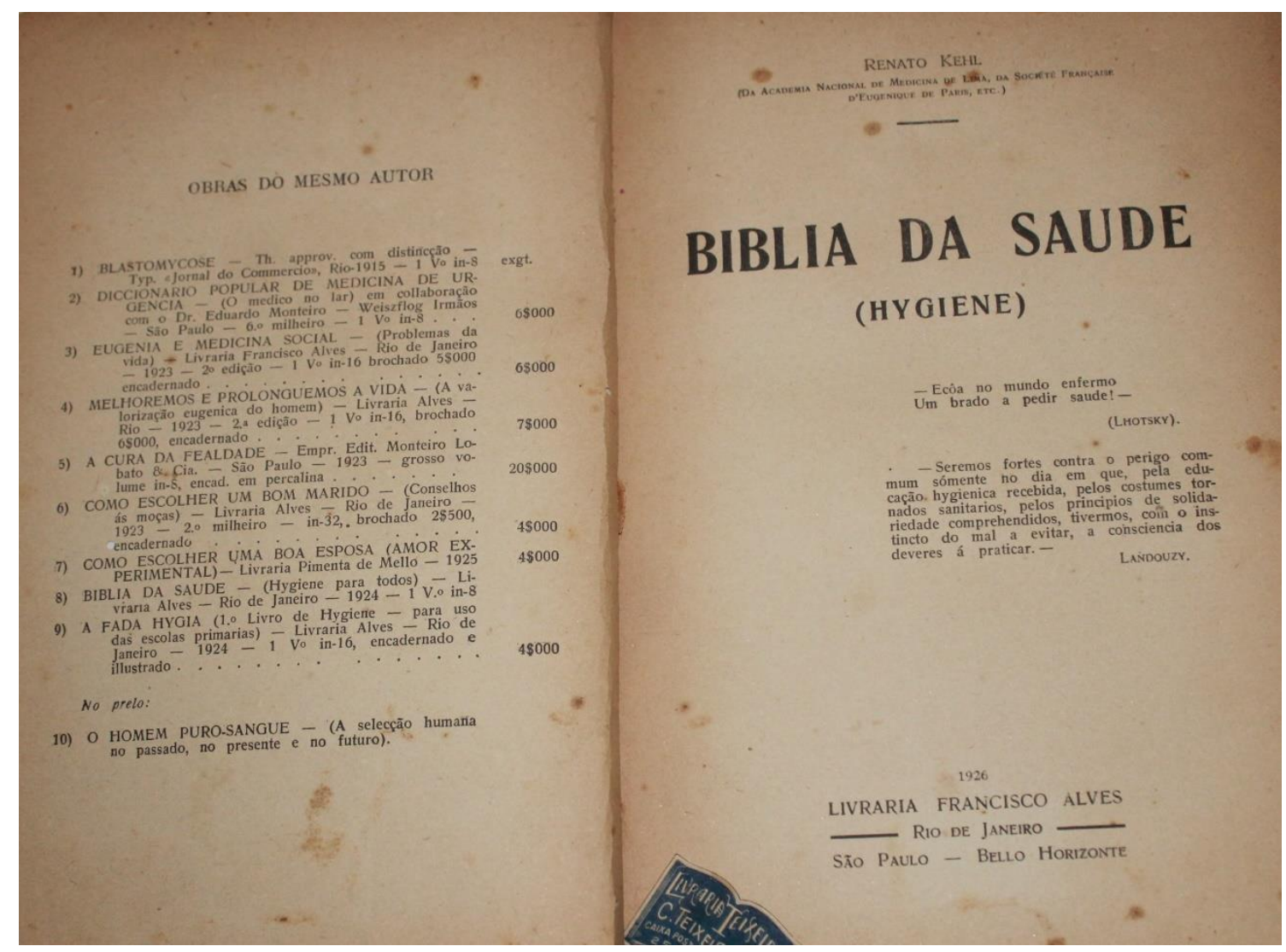

Figura 2. Reprodução da contracapa da obra Biblia da Saude (Hygiene) (1926).

Preocupou-se o autor em elucidar seu entendimento sobre cada uma destas especialidades, delimitando seus propósitos e áreas de atuação.

Seria a higiene a "arte de conservar a saúde", uma série de atitudes coordenadas para proteger-se, prolongar a vida, expurgar as pestes, infecções, sanear espaços insalubres e valorizar o solo. Não tanto uma ciência, segundo o autor, sendo mais próxima da arte da aplicação dos conhecimentos.

Já a medicina social seria uma comunhão de todas as ciências, em cooperação para a melhoria da vida em sociedade e para a vida biológica. Caberia ao campo sintetizar e aplicar os resultados científicos em geral, de modo que fossem capazes de modelar costumes e leis visando a proteção da vida física, dos aspectos morais e econômicos das 
sociedades.

Por último, a eugenia. Esta seria uma

... uma verdadeira sciencia-religião. Harmoniza e concretiza idéas e intuitos regeneradores, esforçando-se para a formação de caracteres optimos, transmissíveis por herança, concorrendo, ao mesmo tempo, para a eliminação das taras e degenerações. (KEHL, 1926, p. 16)

A eugenia cuidaria, portanto, dos conhecimentos acerca da hereditariedade e, como ciência aplicada, da administração dos aspectos positivos e negativos destes caracteres. A hereditariedade torna-se, assim, questão central para a nascente eugenia. Afirma Kehl que a boa hereditariedade seria um capital mais valioso do que o ouro e as pedras preciosas, patrimônio vital que garantiria a verdadeira felicidade:

Felizes os que recebem ao nascer o patrimônio vital integro; desgraçados (são estes tão numerosos) os que o herdam desfalcado e adulterado. Ninguém deseja ter filhos cegos, surdos, epilépticos, enfraquecidos, legando-lhes a desgraça, a monstruosidade, como ninguém tem o direito de perpetuar a sua doença, fealdade, vicio ou tara mórbida. Entretanto, por descuido, por ignorância, por egoísmo são inumeráveis os que olvidam os deveres para com a posteridade; descuidam-se da vingativa força da hereditariedade e casam-se sem estar em satisfatórias condições sanitárias. (KEHL, 1926, p. 25)

Esta dimensão da tríade da saúde evidencia o poder determinante que a eugenia delegava ao passado biológico para a compreensão do presente. Evidencia, também, que estas determinações estavam- para além das formulações teóricas eugenistas- presentes em idealizações sobre os rumos e domínios da saúde, que deveria, em primeira instância, realizar a prevenção da boa saúde pelo fomento da boa hereditariedade. Este aspecto do preventivismo na Saúde e na Medicina, mesmo que não as definam, esteve presente nas discussões que marcaram a primeira metade do século XX. Se a origem do preventivismo é associada mais ao higienismo do que ao eugenismo, é certo que no plano discursivo estabeleceu nexos com este último. O sanitarista Sérgio Arouca afirma: 


\begin{abstract}
A Medicina Preventiva como formação discursiva emerge em um campo formado por três vertentes: a primeira, a Higiene, que faz o seu aparecimento no século XIX, intimamente ligada com o desenvolvimento do capitalismo e com a ideologia liberal; a segunda, a discussão dos custos da atenção médica, nas décadas de 1930 e 1940 nos Estados Unidos, já sob uma nova divisão de poder internacional e na própria dinâmica da Grande Depressão, que vai configurar o aparecimento de uma redefinição das responsabilidades médicas surgida no interior da educação médica. (AROUCA, 2003, p. 109)
\end{abstract}

Para a contextualização das origens do preventivismo no Brasil, Arouca apresenta a definição do médico, professor, escritor e membro da Academia Brasileira de Letras Júlio Afrânio Peixoto (1876-1947). Interlocutor de Kehl, Peixoto foi integrante da Sociedade Eugênica de São Paulo- fundada pelo colega Kehl - e publicou, em 1938, seu Tratado de Medicina Pública, onde afirma ser a higiene uma nova forma de Medicina, que difere da anterior por se preocupar mais com a saúde e com meios para se evitar as doenças. Pela leitura que Arouca faz de Peixoto, esta seria a Medicina Preventiva como parte da Higiene. E neste emaranhado conceitual, assim define Peixoto esta nova forma de Medicina: “... ela cuida do indivíduo e ainda, antes dele, da espécie e da raça; é a eugenia e a previsão da herança mórbida, a regeneração se possível...” (PEIXOTO citado por Arouca, 2003, p. 33)

Assim, os mecanismos de hereditariedade - tão discutidos à época quanto na atualidade- seriam essa poderosa força vital com capacidade destruidora ou regeneradora. Tal postulado - que se configurou como lei fundamental da eugenia - carrega em si uma específica maneira da conceber a história e as dinâmicas sociais como serva da dimensão biológica, bem como carrega em seu cerne lastro científico para estigmas negativos e formas variadas de intolerância. Refletir sobre o movimento eugenista no Brasil - mesmo que a partir de uma história singular- permite atentar para o quanto de seus determinismos permanecem nas problematizações científicas atuais construídas pelas ciências da saúde. 
O passado, assim, contribui para maior consciência sobre o tempo presente.

\title{
3.2 "Cada qual tem seu papel de herói ou de vilão"
}

O farmacêutico e médico brasileiro Renato Ferraz Kehl ${ }^{23}$ (1889-1974) afirmou em anotações para o futuro livro Bioperspectivas. Dicionário Filosófico que:

\begin{abstract}
Não se aponta uma biografia ou auto-briografia, que ante percuciente análise não denuncia um ou outro ponto novelesco ou romanceado. A vida em si é um romance, desenvolvido em palco restrito e modesto, ou à vista de toda a gente, no imenso cenário do mundo. Cada qual tem o seu papel de herói ou de vilão nos incontáveis dramas que se desenrolam todos os dias. ${ }^{24}$
\end{abstract}

Tarefa complexa e exigente de cuidado, a reconstrução - ou reconhecimentos- de aspectos biográficos dá-se à luz da pergunta inicial do biógrafo. Portanto, pautamo -nos aqui pelos aspectos da história de vida de Kehl que contribuem para a compreensão de sua forma de conceber as ciências, a profissão médica e suas percepções acerca da sociedade na qual viveu. Como propõe o supracitado historiador François Dosse: "não há biografia sem liberdade de pesquisa" 25 . E se a presente pesquisa visa à denúncia daquilo que se pretende superar, é certo que não visa à crítica passional e individualizada ao homem de seu espaço e tempo. Tampouco pretende-se uma biografia em strictu sensu, dada a vasta dimensão que o empreendimento abarcaria.

Atribuir valores de "herói" ou de "vilão" ao biografado pode ser, assim, decorrência imediata do anseio que leva o pesquisador à determinada pergunta, tal seja

\footnotetext{
${ }^{23} \mathrm{O}$ fundo documental Renato Kehl, localizado no campus Extensão, da Fiocruz, é recente e abriga uma vasta gama de documentos pessoais e de divulgação. Ainda suas mais de 30 obras foram publicadas paralelamente aos inúmeros artigos e conferências que compõe o corpus documental.

${ }^{24}$ Essas anotações encontram-se no Fundo Renato Kehl, localizado na Fiocruz/RJ. Trata-se de esboço para o livro Bioperspectivas. Dicionário Filosófico, publicado no ano de 1939. Pasta: RK. PQ. CR. 16.

25 Disponível em: <http://oglobo.globo.com/blogs/prosa/posts/2013/10/19/francois-dosse-nao-habiografia-sem-liberdade-de-pesquisa-512485.asp>. Acesso em: set. 2014.
} 
sua motivação inicial. Citamos um exemplo: "resíduos humanos" é uma expressão negativa - dentre muitas outras - usada por adeptos do movimento eugenistas em seus escritos de divulgação. Utilizavam-na ao indicar indivíduos ou grupos determinados. Em linhas gerais, aqueles que consideravam os “infra-homens". O supracitado Bioperspectivas, que viria a ser publicado em 1938, trata-se, por exemplo, de uma obra plena de metáforas de valoração negativa, as chamadas metáforas da exclusão. ${ }^{26}$ Como observamos no breve livro Por que sou eugenista:

Como disse Pitard, catedrático de antropologia da Universidade de Genebra: "por uma má interpretação do que devia ser uma seleção eficiente, a sociedade faz esforços consideráveis de toda a sorte para conservar os tipos inferiores. Nunca foram tão numerosos como hoje os auxílios sentimentais e econômicos que se prestam ás enfermidades físicas e sociais. Os próprios Estados esforçam-se, aumentando as cargas contributivas para fazer viver e triunfar (graças á sua ativa produção), os degenerados físicos, psíquicos e os crimonosos. Em toda a parte são criadas e prosperam as associações destinadas á conservação destes resíduos humanos. Onde existem, porém, (á exceção dos institutos científicos, que carecem ainda de valor social), sociedades para proteger e alentar os elementos mais úteis á humanidade? Conhecem-se algumas, mas em reduzido numero! Muitos, dentre os fortes, os sadios, os inteligentes, os honrados, dentre os que estão, por si e por sua descendência, mais capacitados para realizar progressos, não encontram qualquer apoio útil, devido aos erros sociais que, via de regra, os sacrificam á humanidade degenerada!'. (KEHL, 1937, p. 16-17)

Felizmente, expressões como estas atualmente causam sério estranhamento.

Felizmente, o estranhamento indica que os anseios que levaram aos questionamentos feitos pelos supracitados $^{27}$ precursores da bioética foram, pelo menos em partes, considerados: a equidade de direitos entre os humanos pelas quais tanto se lutou parece, se não resolvida, ter trilhado um rumo que segue percorrendo.

Este mesmo estranhamento mostra que parte de nossa sensibilidade está mais

\footnotetext{
${ }^{26}$ Sobre os sistemas de representação e as metáforas da exclusão há importante obra da antropóloga Martine Xiberras: XIBERRAS, Martine. As teorias da exclusão: para uma construção do imaginário do desvio. Lisboa: 1993, Instituto Piaget.

${ }^{27}$ Introdução, p. 04.
} 
educada. Sensibilidade esta que se torna um desafio ao historiador que se debruça sobre os discursos produzidos pelos movimentos eugenistas: como se posicionar entre o desejo e o impulso de denunciar aquilo que fere o próprio sistema de valores e a responsabilidade de compreender indivíduos a partir de valores e relações próprias de seu tempo e do campo em que viveram?

Por um lado, preza-se pelo rigor das teorias e métodos próprios do campo da História, por outro, julga-se aquilo que se deseja combater.

O presente trabalho busca o equilíbrio entre estes questionamentos. Ressalta-se, portanto, que a valoração negativa de indivíduos que fizeram o movimento eugenista não consiste em objetivo, em momento algum. Mas busca-se a crítica - e aqui o objeto que se critica pode ser tanto singular, próprio do momento, quanto apenas aparentar sê-lo, tendo persistido - a determinados sistemas de valores e perspectivas acerca da vida de caráter excludente e segregacionista.

Walter Benjamin, ao dissertar em 1940 sobre as renovações que os métodos do materialismo histórico trariam se comparados com os tradicionais formatos factuais e laudatórios dos "investigadores historicistas" afirma que estes, ao olharem para o passado, demonstravam empatia uma "relação em empatia com o vencedor". Para a nova forma de fazer História, da qual era arauto, o rompimento com o método tradicional se daria pelo próprio rompimento com a "inércia do coração", ou acedia, que tornaria seus resultados fugazes e poucos reflexivos, por seu julgamento. Ao final de sua sétima tese, afima que seria tarefa deste novo historiador "escovar a história a contrapelo" (BENJAMIN, 1994, p. 225). 


\section{3 "Mais cientista, menos filósofo"}

A compreensão de determinado evento histórico - tal qual um movimento social, científico, ou uma história de vida - se dá pelo estabelecimento de relações dialéticas e reflexões sobre o contexto que o produziu. Interligados, os campos que compõe um contexto são imensuráveis, cabendo ao pesquisador as escolhas que considera mais pertinentes.

Debruçar-se sobre Brasil e, de maneira mais ampla, sobre o Ocidente quando da transição do século XIX e primeira metade do século XX é deparar-se com eventos múltiplos, em ebulição. Não à toa o historiador Eric Hobsbawn nomeou uma de suas importantes obras sobre o período como Era dos Extremos: O breve século XX (19141991). Definições de fronteiras, de posições hegemônicas, imperialismos e, principalmente, as guerras marcaram o período, vivido à sombra do sentimento de perigos iminentes e da inevitabilidade das catástrofes, que ganhavam força a cada acordo de paz desrespeitado:

\footnotetext{
Locais, regionais ou globais, as guerras do século XX iriam dar-se numa escala muito mais vasta do que qualquer coisa experimentada antes. Das 74 guerras internacionais travadas entre 1816 e 1965 que especialistas americanos, amantes deste tipo de coisa, classificaram pelo número de vítimas, as quatro primeiras ocorreram no século XX: as duas guerras mundiais, a guerra do Japão contra a China em 1937-9, e a Guerra da Coreia. Cada uma delas matou mais de 1 milhão de pessoas em combate. A maior guerra internacional documentada do século XIX pós-napoleônico, entre Prússia-Alemanha e França, em 1870-1, matou talvez 150 mil pessoas, uma ordem de magnitude mais ou menos comparável às mortes da Guerra do Chaco, de 1932-5, entre Bolívia (pop. C. 3 milhões) e Paraguai (pop. C. 1,4 milhão). Em suma, 1914 inaugura a era do massacre. (HABSBAWN, 1995, p. 32)
}

O Brasil, jovem país que se inseria no concerto das nações, partilhava das mazelas 
que assolavam a Europa, ora delas se beneficiando pelas exportações, ora se prejudicando com as crises gerais. Mas mesmo não estando oficialmente envolvido em nenhum dos citados conflitos do início do século XX, é certo que, internamente, enfrentava seus inúmeros - e grandes - problemas. Ao transitar da monarquia e da economia predominantemente cafeeira - baseada na estrutura socieconômica da escravidão - para mudanças políticas que levaram à esperada Abolição (1888), instauração da Primeira República (1889) e dinamização da estrutura com a libertação dos escravos e chegada dos imigrantes, o país viu-se diante de desigualdades e contradições vertiginosas: miséria, consequências danosas da Guerra do Paraguai, conflitos no âmbito religioso, militar e, sobretudo, desmandos políticos formavam conturbado panorama e ecoavam gritos revoltosos, como os de Canudos. Não obstante, o processo de urbanização dava-se em ritmo acelerado. As cidades em formação, também imagens das mazelas do período, inspiravam, ao mesmo tempo, ares de modernização. Afirma o historiador Boris Fausto que:

Todas as cidades cresceram. Mas o salto mais espetacular se deu na capital do Estado de São Paulo. A razão principal desse salto se encontra no afluxo de imigrantes espontâneos e de outros que trataram de sair das atividades agrícolas. A cidade oferecia um campo aberto ao artesanato, ao comércio de rua, às fabriquetas de fundo de quintal, aos construtores autodenomidados "mestres italianos", aos profissionais liberais. Como opção mais precária, era possível empregar-se nas fábricas nascentes ou no serviço doméstico. (FAUSTO, 2003, p. 234)

Renato nasceu na cidade de Limeira, no Estado de São Paulo, no dia 22 de agosto de 1889, no calor das controvérsias abolicionistas e do surgimento desta nova dinâmica social, incrementada com camadas intermediárias de trabalhadores imigrantes: alguns vivendo em situações análogas à escravidão, outros em nítida situação emergente, como parece ser o caso de seus familiares. Os registros familiares que demonstram apreço pelos livros e acesso à melhor formação educacional da época assim sugerem. A cidade, por 
sua vez, contava com cerca de 27 mil habitantes, tendo como principal atividade econômica a produção do café, da cana de açúcar e gêneros alimentícios em geral.

Seus avós paternos Jacob Kehl (1819-1908) e Tereza Von Lechthaler (18171902) eram imigrantes alemães que se estabeleceram inicialmente em Campinas, também interior do estado de São Paulo. Jacob, de convicção protestante e Tereza, "católica e parteira", de acordo com registros familiares ${ }^{28}$. Renato era filho do casamento entre o filho de Jacob e Tereza, Joaquim Maynert Kehl (1856-1931) e Rita de Cássia Ferraz Kehl $(?)^{29}$. Seu pai Joaquim - conhecido como “Capitão Kehl”, alcunha que atualmente nomeia rua central da cidade de Limeira - foi médico formado em medicina pela Escola de Medicina de São Paulo em 1883, tendo atuado, no entanto, como farmacêutico e empresário do ramo de "preparados pharmaceuticos", produzindo as "pastilhas Kehl”. ${ }^{30}$

\footnotetext{
${ }^{28}$ Idem.

${ }^{29} \mathrm{O}$ arquiteto Antônio Kehl, neto de Renato Kehl, sobre sua ascendência disponibiliza para interessados e pesquisadores a seguinte anotação, encontrada em escritos familiares: "Originário da Turingia, o nome Kehl, que ja fora Kell ate 1460, perdeu, entao, um L em favor do H. Emigrando, este titulo foi aparecendo em outro paises, principalmente no continente americano, inclusive o Brasil, onde vieram ter dois grupos. Um desses grupos formou-se com a chegada de Jacob Kehl (1819-1908) e Tereza Von Lechthaler (18171902), pais de Joaquim Maynert Kehl (1859-1931) e de mais dois filhos falecidos na Alemanha. Instalouse em Campinas. Viveu 89 anos. De estatura mediana, barbado mas sem bigode, olhos azuis, alegre, brincalhao e muito forte. Gostava de Walter Scott, Goethe e Schiller. Era protestante. Tereza era parteira. Pequena, forte, cabelos pretos, viva, gostava de leitura, assinando revistas alemãs. Era catolica." Disponível em:

<https://www.facebook.com/photo.php?fbid=2205005479406\&set=a.2204829235000.2122526.10754421 23\&type $=3 \&$ theater $>$. Acesso em: ago. 2014.

${ }^{30}$ Em discurso na cerimônia de sua posse na Academia Nacional de Farmácia, ocorrida no recente ano de 2010, assim disse Acácio Alves de Souza Lima Filho: “A cadeira 81, que passo a ocupar, tem como patrono Dr.Joaquim Maynert Kehl, Farmacêutico nascido em Campinas ,em 1856 , e que completou os estudos no Rio de Janeiro, na Faculdade de Medicina e Farmácia do então Município Neutro do Império. Exerceu a profissão na cidade de Limeira e fundou, juntamente com o Barão Raymundo Duprat, a Companhia Química Industrial. Dr. Joaquim Kehl participou e colaborou na fundação da Sociedade de Farmácia e Química de São Paulo e a ela doou toda a sua biblioteca, tendo por duas vezes ocupado a Presidência . Foi um dos fundadores da Academia Paulista de Medicina e colaborou na elaboração da Farmacopéia Paulista, em 1917. Faleceu em 19 de junho de 1931. Sucedeu-o, na cadeira 81, o filho, Dr Renato Kehl ,e posteriormente o Dr Paulo Henrique Mendes. Espero honrar meus antecessores ocupando agora essa cadeira.". Disponível em: 〈http://www.academiafarmacia.org.br/discursos_acacio.php>. Acesso em: set. 2014.
} 


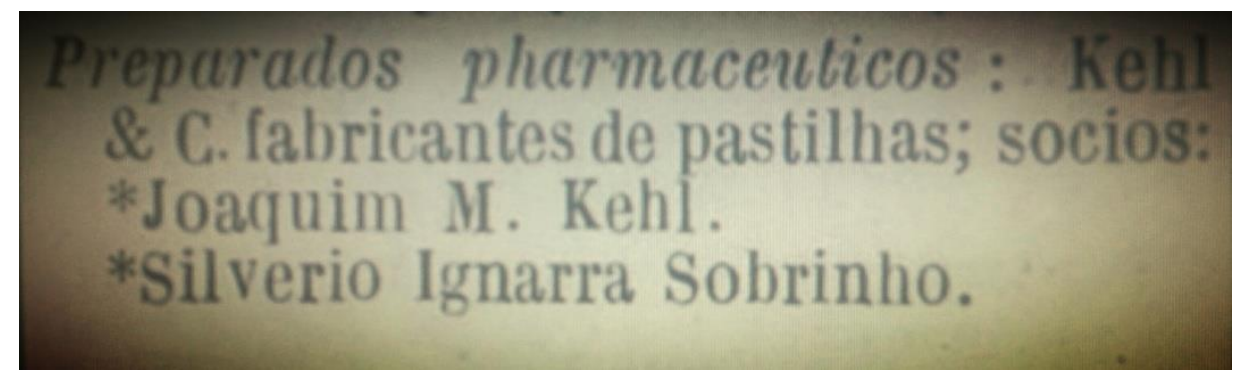

Figura 3. Propaganda dos preparados farmacêuticos Kehl. Fonte: Almanak Administrativo, Mercantil e Industrial do Rio de Janeiro - 1891 a 1940. Fonte: O Estado de São Paulo, 1903, p. 1563.

Na cidade de Limeira Renato viveu até sua juventude. Concluiu o curso ginasial na concorrida Escola Nogueira Gama, na cidade de Jacareí, um dos poucos colégios existentes no estado de São Paulo, cuja importância foi reconhecida pelo presidente Manuel Ferraz de Campos Salles, que o nomeou "Ginásio Nacional”. Após a conclusão da educação escolar, mudou-se para São Paulo, matriculado no curso de Farmácia, por influência de seu pai. Sobre isso, afirmou em discurso ao ser empossado como membro efetivo da Associação Brasileira de Pharmaceuticos, anos mais tarde:

\begin{abstract}
Estudei pharmacia attendendo ao desejo de meu Pae, também pharmaceutico, que sempre almejou ter um filho para successor de sua antiga e conhecida pharmacia de Limeira, no Estado de São Paulo. Formado, passados poucos dias, para lá me dirigi, assumindo a direcção do estabelecimento, do qual se afastara o meu progenitor, arrastado para uma industria a que se havia ligado na Capital do Estado. Exerci a profissão por algum tempo, ate que circunstancias extranhas também me enleiaram, attrahindo-me para os domínios em que agora me encontro. Nasci numa pharmacia, dentro della fui criado, chegando a ser chefe de uma e depois de um laboratório chimico industrial. Sou, pois, bem pharmaceutico. Alguns annos decorreram da minha actividade nessa profissão. Encontro-me, agora, novamente, ás voltas com pharmacia, ou melhor, entre pharmacia e a medicina... ${ }^{31}$
\end{abstract}

Formou-se aos vinte anos (1909) pela antiga Escola de Farmácia da Universidade de São Paulo. As afinidades com a área médica, no entanto, o levaram a mudar-se logo

31 Discurso pronunciado no dia 26 de abril de (?). Recorte avulso. Fundo Renato Kehl. DAD-COC. Pasta RK. PQ. LI. 003. 
depois para o Rio de Janeiro, então Capital Federal, onde alguns anos mais tarde, em 1915, concluiu o doutorado pela Faculdade de Medicina da Universidade do Brasil, ocasião em que defendeu a tese "Blastomycose". Seu irmão Wladimir com ele se mudou para o Rio de Janeiro, tendo cursado também Medicina e defendido, no mesmo ano que o irmão Renato, a tese "Diagnóstico funcional do baço pela adrenalida". Percorreu, desta maneira, caminho inverso ao paterno, indo da farmácia para a medicina, enquanto Joaquim migrou da medicina para a farmácia, áreas estas que, obviamente, mantêm muitos nexos.

O período da formação intelectual de Kehl coincide com o período de recepção das ideias eugenistas no Brasil. Os encantamentos de Kehl com os princípios da chamada nova ciência eugênica não foram singulares. Destas afinidades partilharam Belisário Penna - pai de Eunice Penna, veio a ser seu sogro e também foi seu chefe enquanto Renato trabalhou no posto de Prophylaxia Rural na povoação de Merity, perto da capital do Rio de Janeiro -, Agostinho de Souza Lima, Afrânio Peixoto, Miguel Pereira, Miguel Couto, o literato Monteiro Lobato, o jurista Oliveira Vianna, dentre muitos outros sobre os quais discorreremos adiante. Kehl se inseria, assim, em uma rede de amizades e relações profissionais cuja escola de pensamento contava com mentores como Lamarck, Darwin, Spencer, Agassiz, Weismann e, principalmente, Galton.

Enquanto os eugenistas pioneiros europeus e norteamericanos realizavam seus primeiros esforços em forma de publicações, congressos e criação das primeiras cátedras universitárias em instituições que adotaram a eugenia como disciplina ${ }^{32}$, no Brasil esta "nova forma de ciência" encontrava-se diluída, ainda nascente, mas sendo inserida dentre as variadas especialidades médicas.

\footnotetext{
32 Vide capítulo 1.
} 
A tese "Blastomycose" - produzida por Kehl durante sua formação em medicina - trata de uma doença infecciosa, causada por um fungo - ou cogumelo, como era dito na época - que se reproduzem assexuadamente por germinação e se alimentam de detritos orgânicos. A doença, quando instalada, não é disseminada por contato direto entre humanos ou animais, mas aspirada por vias pulmonares. $\mathrm{O}$ fungo, uma vez disseminado, por causar pápulas purulentas na pele, tumefações dolorosas nos ossos e prostatite em homens. Se não cuidada, por evoluir lentamente até levar à morte. Comum nas zonas rurais (sobretudo em regiões da América do Norte), a blastomicose é, portanto, doença que exige profilaxia.

Ao início de sua tese, Kehl esclarece a abordagem inovadora (para a época) que era permitido dar ao problema da blastomicose após o abandono da teoria miasmática e inovações ouriundas da bacteriologia. Apesar de não se tratar de uma bactéria, afirma, os métodos experimentais inovadores da área permitiram a compreensão da dinâmica de vários outros patogênicos, como o referido cogumelo. O processo empregado para o estudo teria sido, portanto, o mesmo da bacteriologia: exame microscópico do material da lâmina, formação de culturas em temperatura ambiente, inoculação em animais (ratos brancos ou "micos" previamente imunodeprimidos com ópio) e verificação, por método observacional, do poder patogênico e das "lesões experimentaes" (KEHL, 1915).

Pela análise de sua tese, bem como de sua formação oficial, percebemos a eugenia ainda tímida, estando ligada, inicialmente, aos anseios profiláticos. Entre os ímpetos que levavam aos estudos para evitar as doenças e, posteriormente, os que preconizavam evitar a existência dos doentes, é evidente que foram dois tipos de convicções que coexistiram, prevalecendo ora uma, ora outra. Tal coexistência permite melhor compreender certas aparentes contradições e inserir ao debate a vertente que também produzia conhecimento sobre questões da saúde, mesmo que à sua maneira. Ao final da introdução de sua tese, 
cita os dermatologistas franceses Beurmann e Gougerot: "Ao mesmo tempo em que nossos conhecimentos gerais sobre as infecções micológicas se tornam mais precisos, seu número e sua frequência aumentam, sua importância se revela cada vez maior” (Idem).

No quadro docente da Faculdade de Medicina do Rio de Janeiro da década de 1910, podemos observar a presença de nomes que, juntamente com Kehl, se tornaram profícuos eugenistas. Presume-se, assim, que por sua formação e contato com teóricos se deu o encantamento pelo tema: 


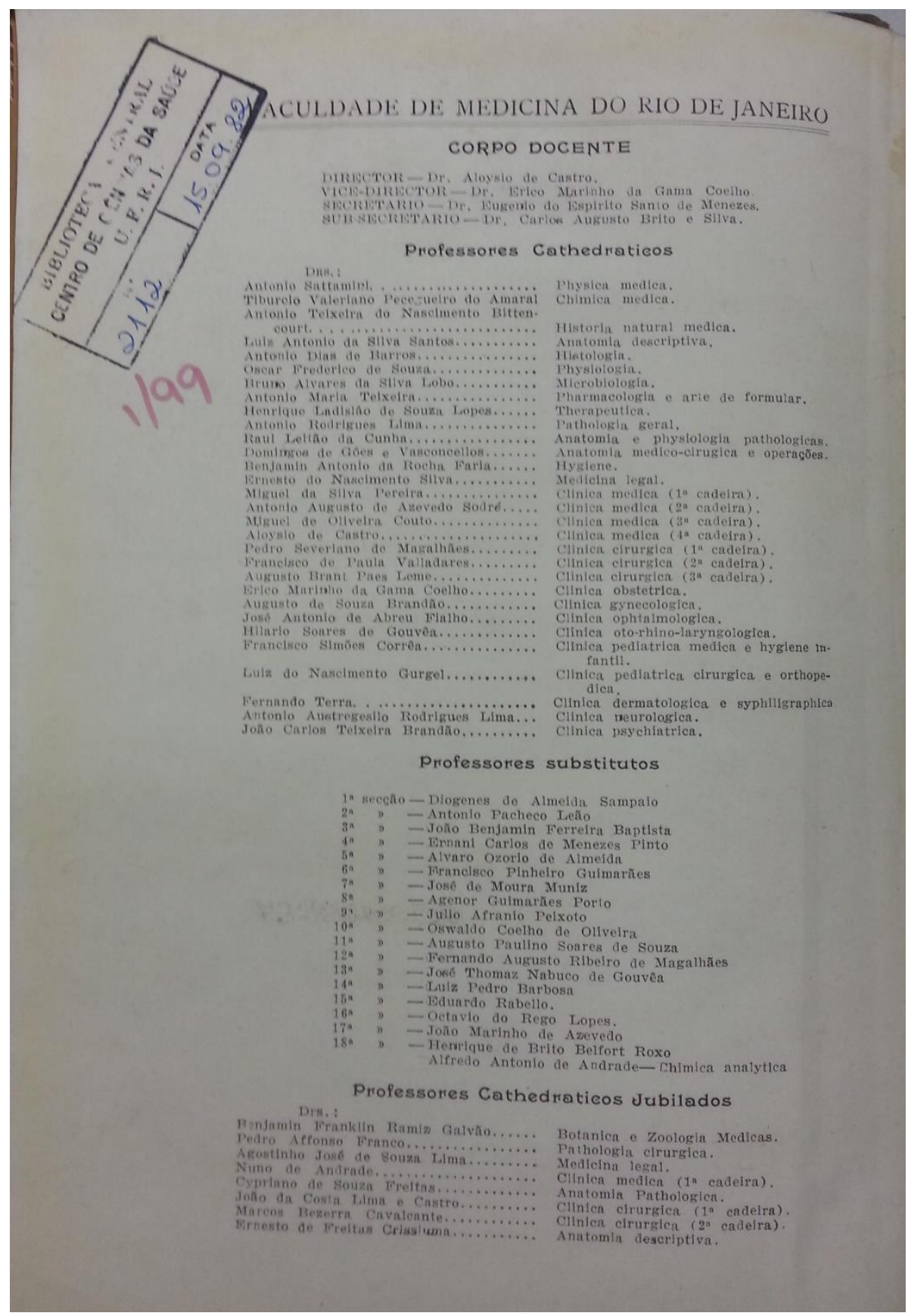

Figura 4. Tese Blastomycose, defendida por Kehl. Faculdade de Medicina do Rio de Janeiro, 1915.

Da "pharmacia e arte de formular", passando pelos princípios da higiene, pelo evolucionismo da história natural às aulas de clínica médica de Miguel Couto, a matriz de pensamento de Kehl e seus colegas elucida-se.

Vanderlei Sebastião de Souza chama a atenção para a sincronicidade, por volta de 
1912, quando da realização do I Congresso Internacional de Eugenia:

\begin{abstract}
Um ano após a realização do Primeiro Congresso Internacional de Eugenia- do qual participaram médicos, biólogos e eugenistas como Leonard Darwin, Karl Pearson, Charles Davenport, August Weismann e mais de 750 cientistas de vários países, sobretudo da Europa e dos Estados Unidos-, Renato Kehl teria escrito seu primeiro trabalho sobre eugenia, "anexo a um estudo sobre as teorias de August Weismann", que, como era o seu intuito, deveria ter sido apresentado como tese para sua conclusão no curso de medicina. Contudo, como ele mesmo ressaltava anos mais tarde, devido à dificuldade de se lidar com um assunto tão complexo e ainda pouco conhecido entre os intelectuais brasileiros, o trabalho não teria sido publicado naquele momento, conservando-se inédito. (SOUZA, 2006, p. 70)
\end{abstract}

Por volta de 1917, já em São Paulo, para onde se mudou novamente após o doutorado em medicina, Kehl assumiu a missão de publicista da campanha eugenista no Brasil, dando início aos estudos, publicações, palestras ministradas e criação de sociedades eugenistas. Essa atividade foi perene em sua vida, ocorrendo paralelamente à prática clínica e ao posto de farmacêutico responsável e diretor médico na antiga empresa “A Química Bayer Ltda”, onde permaneceu dentre os anos de 1923 até fins de 1944. Ainda quando na Bayer, Renato Kehl dirigiu os periódicos O Farmacêutico Brasileiro, a Revista Terapêutica e o Boletim de Eugenia, atuando como profícuo escritor sobre temas variados. Pela empresa, onde criava propagandas para os fármacos diversos, fez importantes viagens, tendo entrado em contato direto com vertentes eugenistas mais radicais. Souza observa que após quatro anos em que esteve na Bayer, Kehl, que inicialmente atuou como técnico farmacêutico e em 1928 já atuava como diretor médico e chefe de laboratório, embarcou com sua esposa Eunice para uma viagem de 5 meses pela Europa, viagem esta noticiada com entusiasmo pela imprensa:

Embarcou anteontem, com destino à Alemanha, o conhecido médico e publicista Dr. Renato Kehl. Espírito brilhante, forrado com um grande amor ao 
trabalho, o Dr. Renato Kehl tem sido um devotado divulgador da eugenia entre nós, não só em colaboração ativa entre os nossos mais importantes diários, como em profusos livros que tem publicado, com o mais extraordinário sucesso. A sua viagem à Alemanha, como nos disse, é feita a título recreativo, mas estamos certos será mais uma viagem de estudos aos grandes centros da cultura germânica, sempre fontes de inesgotáveis ensinamentos científicos. (SOUZA, 2006, p. 74)

Como clínico, Dr. Renato Kehl atuou inicialmente como cirúrgico e geriatra, se tornando, em seguida, "especialista em syphilis e vias urinarias (molestias dos rins, bexiga, prostata e urethra)" em consultório na Rua Libero Badaró, $\mathrm{n}^{\circ} 119$, na cidade de São Paulo. Lilia Blima Schraiber em seu livro O médico e seu trabalho: limites da liberdade atenta para o significado do "fazer-se médico" à época: a profissão, afirma, representaria possibilidade de ascenção e participação social, gozando de específico prestígio. Ainda, para alguns, tal como Kehl, a escolha representava uma continuidade familiar. Para outros, rompimentos com antigas tradições como, por exemplo, a atividade agrícola familiar. Havia ainda aqueles para os quais o fazer-se médico representava rompimento com situações de pobreza. Elemento comum seria considerar a medicina como "encanto, esperança, conquista" 33 . Cabe, ainda, ressaltar que a localização do citado consultório corrobora a situação de prestígio profissional.

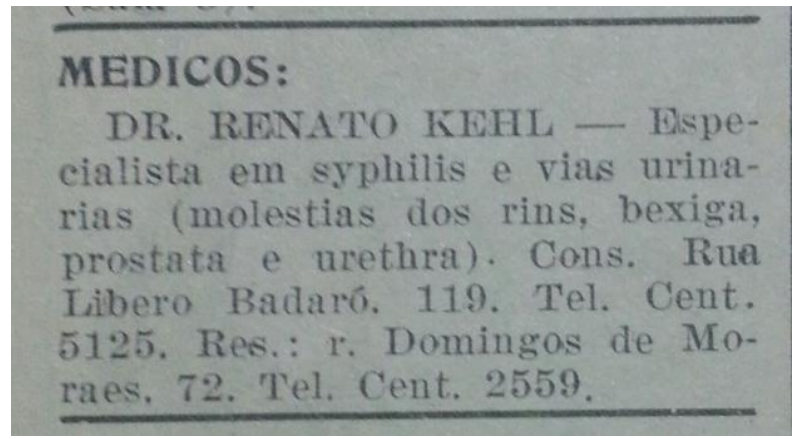

Figura 5. Divulgação de serviços. Fonte: Sessão Indicador da Revista do Brasil. N³7- Anno IV. Vol. X. Janeiro, 1919.

${ }^{33}$ SCHRAIBER, Lilia Blima. O médico e seu trabalho: limites da liberdade. São Paulo: Hucitec, 1993. p. 54. 
Complementando sua prática médica, sua função empresarial e eugenista, as relações de Kehl se davam por intensas trocas de cartas que compõem seu arquivo pessoal e documentam as trocas de ideias e de publicações que travou com intelectuais de diversas partes do mundo. Nas palavras de Pietra Diwan, que em sua dissertação se debruçou especialmente sobre as correspondências pessoais:

O termo publicista serve bem para determinar a atuação de Renato Kehl no movimento eugenista. Ele divulgava os 'fatos' novos a seus interlocutores, como os lançamentos de livros; intercambiava endereços com outros eugenistas do mundo; fazia convites para conferências; solicitava opiniões editorais, etc. (DIWAN, 2003, p.82)

A profusão de atividades que compõe sua trajetória é significativa. Assim consta em texto laudatório publicado na Revista Terapêutica por ocasião dos seus 70 anos:

Não se preocupou, contudo, apenas com a ciência e arte eugênicas. Volveu a atenção também para os problemas correlatos da medicina social, da higiene mental e da educação, propagando suas ideias doutrinárias através do rádio e da imprensa. O seu labor incansável no campo das investigações científicas grangearam-lhe numerosas distinções e cargos honorários. (Revista Terapêutica, 1939) 


\section{Dados biográficos}

do

\section{Dr. Renato Ferraz Kehl}

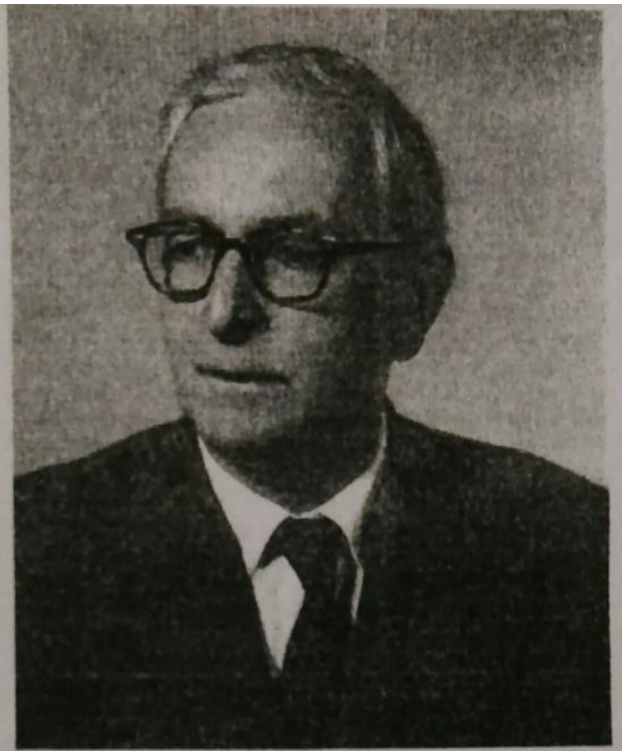

O Dr. Renato Ferraz Kehl nascido em Limeira, no Estado de São Paulo, a 22 de agosto de 1889, fitho de Joaquim Maynert Kehl e Rita de Cássia Ferraz Kehl, completa neste ano 70 anos de idade.

Formou-se aos vinte anos pela antiga Escola de Farmácia da Universidade de Sâo Paulo, e posteriormente, em 1915, doutorou-se em medicina pela Faculdade de Medicina da Universidade do Brasil (Rio de Janeiro), defendendo a tese «Blastomicose », aprovada com distinção.

Tendo-se dedicado aos problemas heredológicos e aos princípios da Eugenia, fundou em 1918 a Sociedade Eugênica de São Paulo, a primeira no género aparecida na América do Sul, e que contava, então, cento e quarenta médicos.

Lutando incansàvelmente pela maior difusão das suas doutrinas, o Sr. Dr. Renato Kehl realizou numerosas conferências no país e no estrangeiro, publicando ainda 30 livros e vários trabalhos cientificos.

Nâo se preocupou, contudo, apenas com a ciência e arte eugênicas. Volveu a atenção também para os problemas correlatos da medicina social, da higiene mental e da educaşão, propagando as suas ideias doutrinárias através do rádio e da imprensa.

O seu labor incansável no campo das investigações cientificas grangearam-lhe numerosas distinçōes e cargos honorários. Assim o Dr. Renato Kehl pertence a muitas instituiģ̃es científicas e estrangeiras, entre elas à Academia Nacional de Medicina e à Academia Nacional da Farmácia, do Rio de Janeiro; à Academia Nacional de Medicina, de Lima; à Sociedade Mexicana de Eugénia; à Eugenic Society, de Londres, ao Institut Internacional d'Anthropologie, de Paris; à Associação Brasileira de Imprensa, do Rio de Janeiro, e várias outras.

A Revista Terapética presta as suas homenagens a esse ilustre cientista brasileiro desejando-the muitos anos de vida e fazendo votos para que continue a actuar com éxito pelo bem do seu país e da humanidade.

De 1.7. 1923 até fins de 1944, o Sr. Dr. Renato Kehl ocupou o cargo de Farmacéutico responsável e Director Médico na antiga firma «A Química Bayer, Ltda.» Nessa firma dirigiu durante muitos anos as revistas \& $O$ Farmacêtico Brasileiro s e a ¿ Revista Terapéutica $\mathbf{3}$.

E pois com grande satisfação que a Redacşão da Revista apresenta as suas cordiais felicitações, ao Sr. Dr. Renato Kehl, também em nome da FFB, sentindo-se honrada pela colaboração prestada e manifestando a sua sincera gratidão.

Revista Terapéutica. $A$ Reda ç̧ão. 
Entre o médico publicista e o médico cientista houve significativas interfaces. Ao assumir a eugenia como missão social, o conhecimento que adquiria ou produzia deveria ser repassado em forma de campanha, das obras ao consultório. Ao assumir o cargo de farmacêutico responsável e diretor médico na Bayer, deveria também fornecer lastro para os produtos que sustentavam a atividade fabril. Sobre essas relações, há elucidativo artigo publicado na mesma Revista Terapêutica, na qual, ao dissertar sobre os “Amantes da Dor" e dividi-los entre algofílicos, algomaníacos e sadi-masoquistas, finaliza com o encaixe da propaganda do medicamento "O Evipana", que se tratava de um sonífero e calmante de ação segura. Ressalta-se, no entanto, que as triplas funções de cuidador, cientista e publicista eram comuns na década de 1930 (SCHRAIBER, 1993, p. 33) 


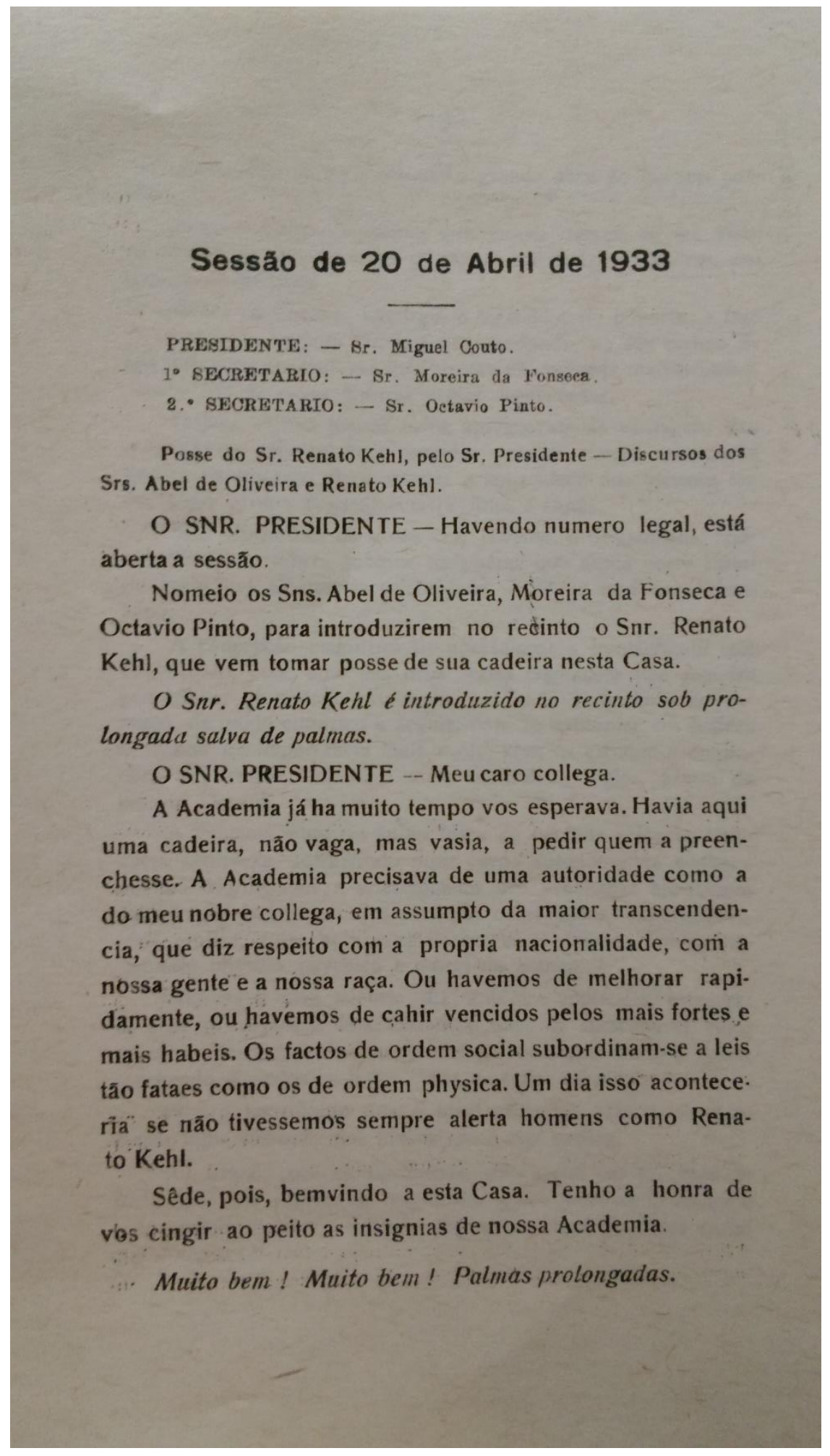

Figura 7. Início do discurso de Renato Kehl quando da posse como novo acadêmico da Academia Nacional de Medicina em 1933. Acervo do Departamento de Arquivo e Documentação Casa de Oswaldo Cruz- FIOCRUZ. Fundo Renato Kehl. 
A socióloga Carolina Kinoshita bem observa que, em correspondência a Kehl,

Lobato afirma que diante da inércia de seus ouvintes, pareceria ele um "Dom Quixote" a

pregar para uma legião de "Panças". A importância das atividades diversas que compõem

sua história profissional, bem como suas relações intelectuais e seus ouvintes - mesmo

que "platônicos" - no entanto, mostrariam o contrário:

Desse modo, longe de ser um Dom Quixote científico e longe também de pregar para uma legião de panças, Kehl fazia parte de um sistema social que simpatizava com os ideais da Higiene e da Eugenia, ao mesmo tempo em que fortalecia as ações de Renato Kehl, até o momento em que elas não eram mais convenientes ao sistema social. Vale destacar que, na década de 1920, quando A Fada Hygia: primeiro livro de Higiene foi publicado, com o propósito de convencer os indivíduos a participar do projeto de saneamento do Brasil, muitos profissionais contribuíram para a divulgação do manual em diversos espaços, inclusive nas escolas, demonstrando, assim, uma conexão desses ideais com as iniciativas de Renato Kehl e da Livraria Francisco Alves de publicar manuais escolares de higiene. (KINOSHITA, 2013, p. 172)

Souza bem localiza Kehl na perspectiva do historiador Nicolau Sevcenko ao

afirmar:

Renato Kehl seguia, neste sentido, um comportamento intelectual que já havia se transformado numa tradição entre os "homens letrados" da Primeira República. Segundo o historiador Nicolau Sevcenko, no início do século XX, jornalistas, literatos, médicos e cientistas desenvolviam a sua atividade intelectual como uma missão política, ou como uma "ação pública", voltada para a reforma e a transformação efetiva da realidade social e política da nação, como coordenadores do processo de mudança em curso. Os intelectuais brasileiros repensavam o país, segundo Sevcenko, "como se seu olhar estivesse postado no próprio centro de decisões, calculando suas possibilidades, medindo seus limites reais". (SOUZA, 2006, p.83) 


\section{Ministerio do TrabaLHO, INDUSTRIA E COMMEROIO}

cossurvo Jumte

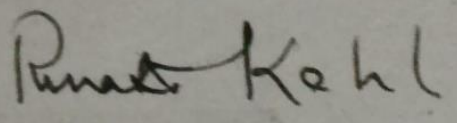

\section{copid}

Snr- Dr- Renato Kehr.

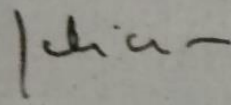

....

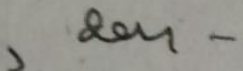

Muito desvanecido pelas suas feli. citações. É que estamos dentro das megmas ideas e caminhando com os mesmos ideais e no sentido dos mesmos objetivos.
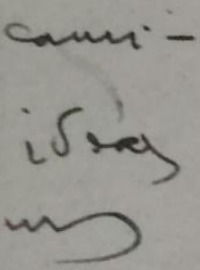

\section{Oliveira Viana.}

is

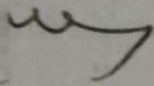

Figura 8. Correspondência de Oliveira Viana. Acervo do Departamento de Arquivo e Documentação Casa de Oswaldo Cruz- FIOCRUZ. Fundo Renato Kehl. 


\section{MINISTERIO DA EDUCAÇÃO E SAUDE FUBIICA}

Meu caro Renato Kehl

Seu livro - "BDUCAÇÃO MORAL" - vale bem o nome do autor. Reflete as virtudes deste, constituindo o melhor exemplo que se pode apontar á juventude.

Ii-o cuidadosamente, meditando a cada passo. Não encontrei senōes. Işso me fez suspeitar de mim proprio. Seil quão exaltada é a minha admiraça pelo autor. Deixei-o, então, ao faoll alcance dos filhos e lhes não disse palavra a respeito, mantendo-me em observação. o primeiro que o leu solicitou a atenção dos outros. Todos se empenharam interessadamente na leitura: tres rapazes e uma menina. Ao meu julgamento, porém, isso não bastou ainda, Bsperei, sempre atento. Fude, afinal, veriflcar o que considero importante no caso:- a eficaz influencia do livro no espirito dos leitores. Entusiasmeime. Confirmara-se o que eu supusera de inicio. Bstou satisfeitissimo. Você prestou mais um assinalado serviço á mooidade! "Cuore" de "BDUCACÃO LORAL" passará á posteríade como Aceite, meu caro Renato, os meus fervorosos cumprimentos e os sinceros agradecimentos que, como bom patriota, the envia o seu amigo certo

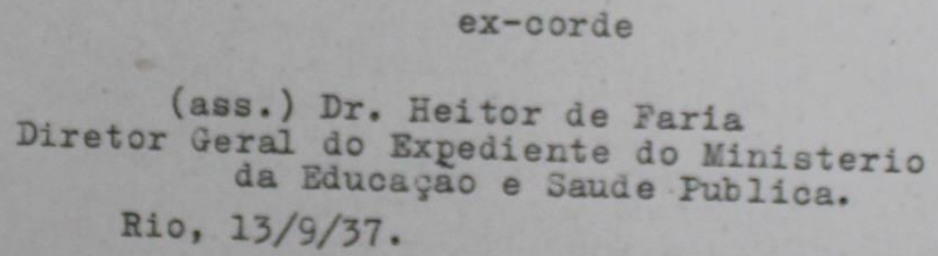

Figura 9. Carta recebida de Heitor de Faria. Acervo do Departamento de Arquivo e Documentação Casa de Oswaldo Cruz- FIOCRUZ. Fundo Renato Kehl.

A supracitada obra Bioperspectivas. Dicionário filosófico define sucintamente suas concepções acerca de termos diversos. Iniciando pelo vocábulo "absurdo" e finalizando com a expressão "voz do povo", concluiu, ao final, que "a ciência ilumina cada vez 
melhor o caminho íngreme da existência, poupando à humanidade os tropeços que dificultam sua ascensão ao reino da saúde, da sabedoria e da concórdia social." (Kehl, 1938, p. 140)

No prefácio do mesmo, o literato Monteiro Lobato ao tecer elogios ao amigo Kehl, afirmou:

Classificar de cientista a um homem de pensamento é pô-lo no rol dos que organicamente repelem tudo quanto não surja com base no experimentalismo dos laboratórios. Quem formula idéias gerais apenas com base na logicidade, não merece tal nome - poderá ter o de filósofo. Renato Kehl me parece o mais acabado tipo de cientista que a nossa atualidade pensante possue. (LOBATO em prefácio a Kehl, 1938) 


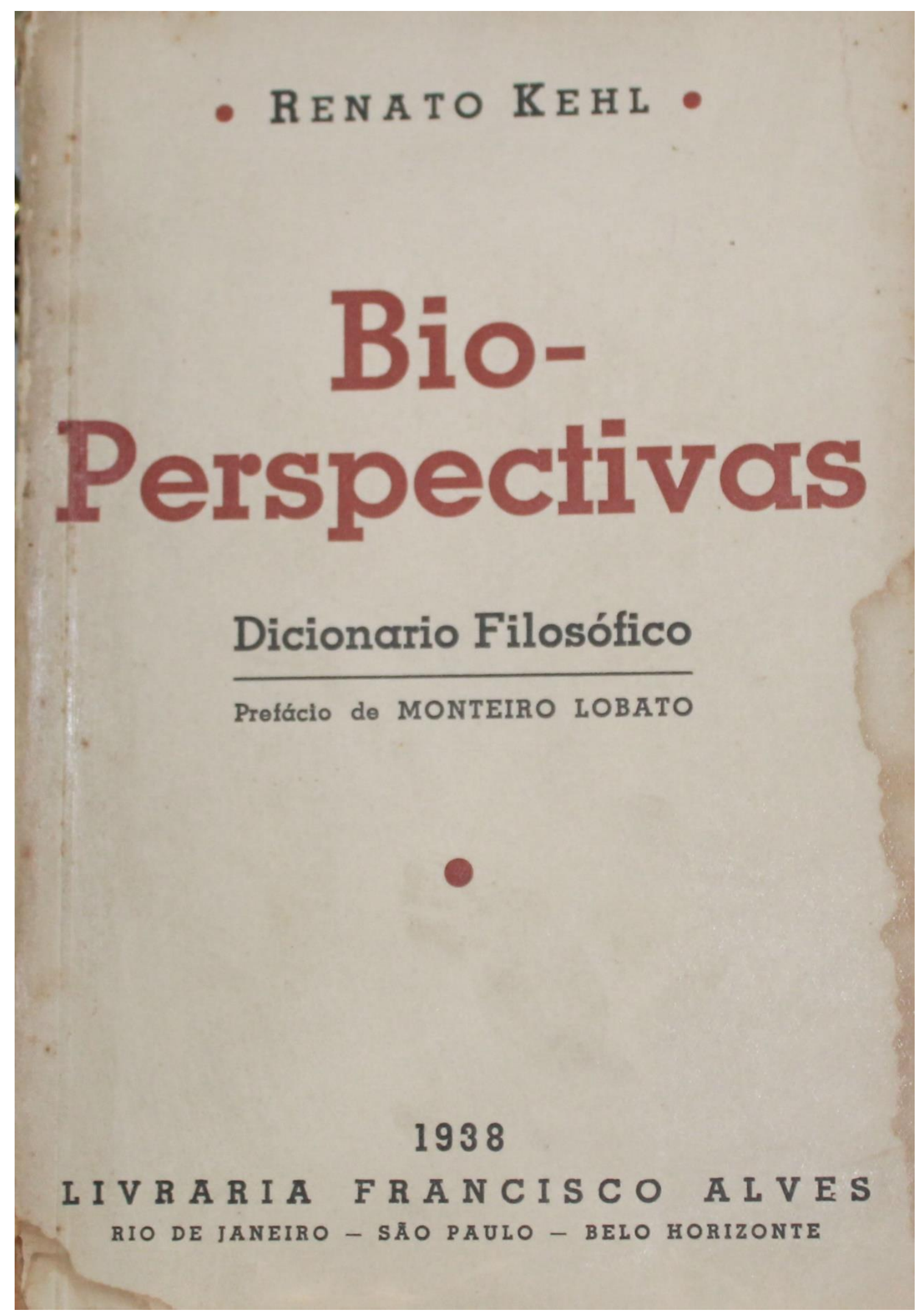

Figura 10. Reprodução da capa da obra Bio-perspectivas: dicionário filosófico (1938) 
Mais cientista, menos filósofo. A afirmação contundente traz em si parte do ethos do momento que a produziu: consolidava-se, também no Brasil, a crença na separação entre as ciências que se consideravam exatas, puramente objetivas, pouco sujeitas às variações dos olhares de seus sujeitos, e aquelas formas de conhecimentos empíricos que seriam tomadas de subjetividade e, portanto, mais filosóficas e menos exatas.

Kehl e Lobato revelam-se, assim, arautos de seu tempo. Relacionada ao processo de racionalização da dinâmica da vida pelas nascentes ciências biológicas - herdeiras das ciências naturais - esteve a configuração do eugenismo brasileiro. Este teve na figura de Renato Kehl - justamente pelos importantes aspectos filosóficos de seus escritos- seu principal articulador e publicista, dentro de uma rede de relações que englobava profissionais de todas as áreas da saúde, juristas, engenheiros, educadores e tantos outros que, por convicções das mais variadas, abraçaram a missão. Missão esta orientada por resultados experimentais - estatísticos, laboratoriais - que, certeiros e científicos, chegariam às verdades, superando as mazelas do "obscurantismo" metafísico. Sobre a importância das interpretações de Kehl e Lobato para o pensamento sobre o Brasil, destaca Ricardo Augusto dos Santos:

Nísia Trindade Lima (1999) e Aluízio Alves Filho (1979), em seus livros, destacam uma característica da bibliografia sobre o pensamento social brasileiro. Estes autores ressaltam que, embora crítica, esta literatura restringese a alguns nomes. Assim, pensadores como Monteiro Lobato, Manoel Bomfim, Belisário Penna, Renato Kehl e outros que interpretaram o país encontram-se um pouco esquecidos. As interpretações sobre a sociedade tiveram a importante participação destes intelectuais, contudo, eles não são reconhecidos como relevantes autores do pensamento brasileiro, embora muitos tivessem sido divulgadores das representações sociais que ainda hoje estão presentes em nosso imaginário social. Este é o caso dos cientistasintelectuais, que participaram da campanha pelo saneamento do Brasil e implantação de uma educação higiênica nos lares e escolas. (SANTOS, 2003)

\footnotetext{
${ }^{34}$ Utilizada a versão eletrônica disponível em: <http://www.achegas.net/numero/sete/ricardo_santos.htm〉.
} Acesso em: out. 2015. 
Renato Kehl faleceu no ano de 1975, aos 85 anos de idade. Até um período próximo ao do seu falecimento, há registro da permanência de suas convicções eugenistas.

\section{4 "Pelo aperfeiçoamento da nacionalidade"}

Em janeiro do ano de 1929, Renato Kehl assistiu a entrega dos prêmios aos vencedores do primeiro Concurso de Eugenia brasileiro, realizado em São Paulo e organizado por uma comissão do Serviço Sanitário do Estado. De uma pré-seleção de 70 candidatos, passando por várias etapas, venceu Adenir Ferreira de Carvalho, logo aos 03 anos de idade, sendo premiada como a " $1{ }^{\circ}$ brasileira eugenizada". Waldomiro de Oliveira, diretor do Serviço Sanitário do Estado, escolheu a comissão que rigorosamente selecionou os primeiros candidatos e, sobre suas características físicas, mentais, ausência de histórico de doenças e, sobretudo, ausência de características indesejadas em seus ascendentes, cuidadosamente aplicou o questionário elaborado para a ocasião. 


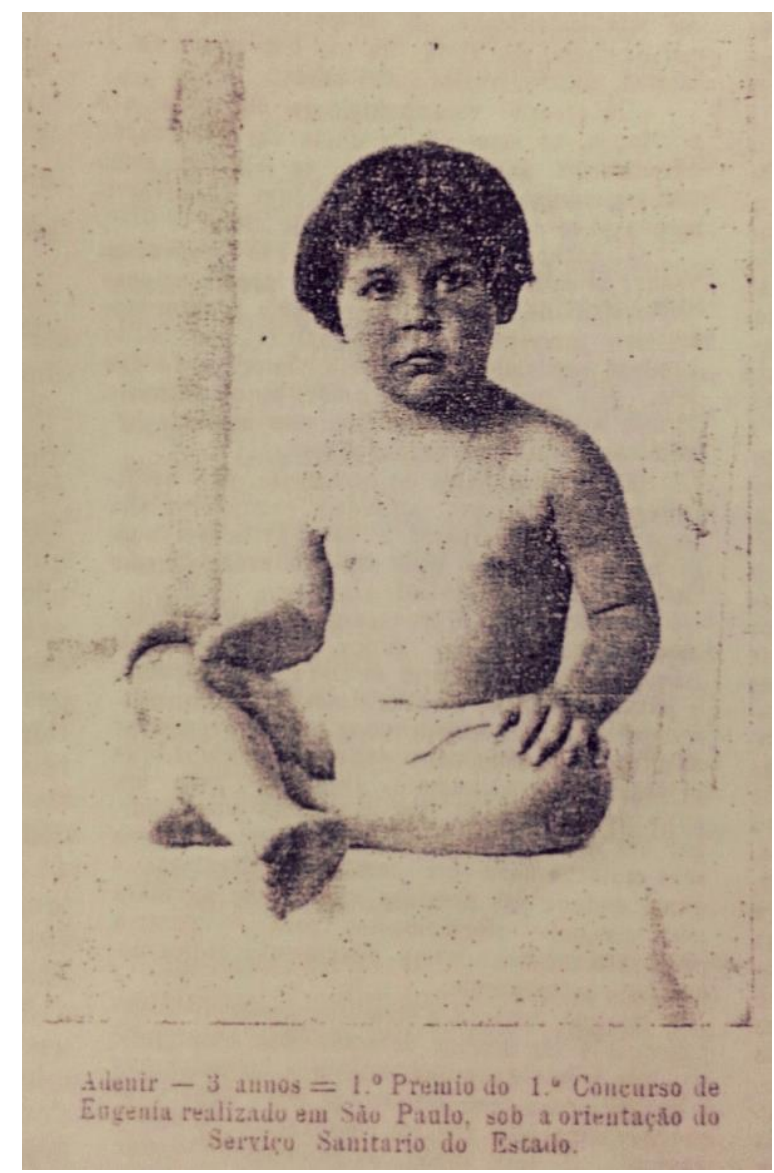

Figura 11. A vencedora do concurso de eugenia. Fonte: Boletim de Eugenia. Maio de 1929. Vol. I - Num. 5. Editado em propaganda do Instituto Brasileiro de Eugenia. Capa.

Exaltando o concurso escreveu Kehl a matéria da capa do Boletim de Eugenia de maio do mesmo ano, intitulada "Pelo aperfeiçoamento da nacionalidade - A $1^{\circ}$ Brasileira Eugenizada". Com entusiasmo, afirma:

Como disse em entrevista concedida ao "O Estado de São Paulo", a São Paulo coube a primazia na fundação da primeira Sociedade Eugênica criada no continente sul-americano e a prioridade na cruzada em pról da sciencia de Galton. Era natural, portanto, que em São Paulo tivesse logar o primeiro Concurso de Eugenia. Exultei com a sua realização. Ella tem alta significação como exemplo e emulação para o fomento da paternidade digna e como testemunho de que a propaganda do aperfeiçoamento eugênico está dando resultados evidentes e valiosos para a nossa terra e para a nossa gente. (Boletim de Eugenia,1929, vol. I ) 
Após a exaltação do concurso e do pioneirismo paulista ${ }^{35}$, justifica:

Um dos mais importantes problemas da sciencia de Galton consiste na seleção dos "bem dotados", isto é, na escolha dos melhor prendados physica, psychica e mentalmente. Dessa seleção, derivam varias consequencias de valor: em primeiro logar, concorre para augmentar o interesse publico, fazendo com que os paes se esclareçam no tocante á constituição de proles sadias e bellas; em segundo logar, serve para a organização de um ensaio de patronagem da futura elite nacional de eugenizados; finalmente, contribue com preciosos elementos para importantissimos estudos relativos á hereditariedade, ao meio social e familiar, ao cruzamento de raças, etc. (Idem)

Proles sadias e belas formariam, desta maneira, a futura elite nacional de eugenizados, segundo os parâmetros relativos à hereditariedade fornecidos pela ciência de Galton. Para o alcance de tal objetivo, fazia-se necessário fomentar o interesse público. Tal tarefa, cujos esforços se iniciaram no início do século XX e perduraram por décadas, não foi tão simples: debates gerados por convicções radicais que levavam aos dilemas morais, debates teóricos acerca dos mecanismos de transmissão de caracteres, debates acerca dos méritos étnicos e até mesmo os debates impostos pela intervenção religiosa ${ }^{36}$ marcaram o desenrolar dos eventos.

\footnotetext{
35 Em sua obra Tropeços da Medicina Bandeirante: Medicina Paulista entre 1892- 1920 (São Paulo: Editora da USP, 2005) André Mota atenta para a construção da imagem de superioridade da medicina paulista que, sob o pilar da excelência tomava para si direitos de comando sobre os rumos do país. Tal tradição, contemporânea do movimento eugenista, por vezes apresenta-se por argumentos semelhantes aos usados pelos defensores da inexorabilidade dos mecanismos hereditários.

${ }^{36}$ Pietra Diwan atenta para a Encíclica Casti Conubii, na qual o Papa Pio XI condenou os propósitos eugenistas. Casti conubbi trata-se de uma encíclica promulgada pelo Papa Pio XI em 1930. Citada por Pietra Diwan na obra Raça Pura por seus aspectos anti-eugenistas, já que afirmava ser a família e certos valores anteriores ao Estado.
} 


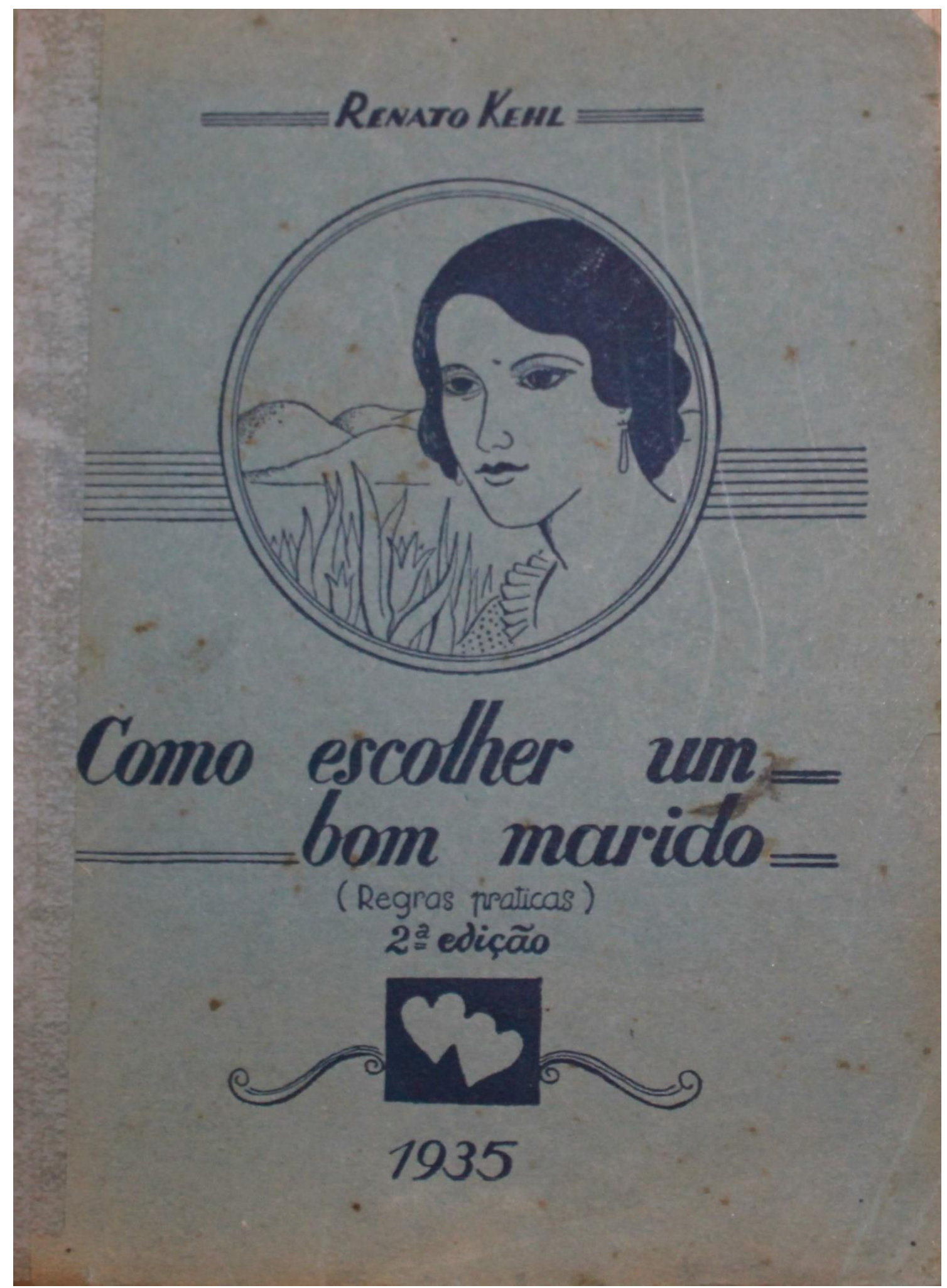

Figura 12. As preocupações eugenistas de Kehl iam do coletivo ao individual. Reprodução da capa da obra Como escolher um bom marido (1935).

Seguindo pelo mesmo periódico, três anos após a realização do primeiro Concurso 
de Eugenia, o geneticista Octavio Domingues, que viria a ser, junto com Kehl, um dos diretores do periódico Boletim de Eugenia, a partir de 1933, membro da “"Eugenics Society' de Londres" - como consta anexado ao seu nome- e pesquisador da Escola Superior de Agricultura Luiz de Queiroz, situada em Piracicaba (atualmente campus da USP) revela, em texto autoral publicado no mesmo Boletim de Eugenia, preocupações com os ramos do movimento no Brasil. Octavio compartilhava do anseio pela eugenização do povo brasileiro. Porém, suas convicções e estudos exaltavam a mestiçagem, ao invés de condená-la. Tal ausência de preconceito com a mestiçagem não anulava o compartilhamento dos estigmas negativos quanto aos considerados doentes mentais e físicos. A matéria em questão, intitulada "Limalhas de um eugenista", assim inicia:

Todos os que trabalhamos na divulgação da eugenia no Brasil, experimentamos um conforto e um estímulo novos ao verificarmos esse movimento de simpatia, no seio de um partido político paulista, quiçá de dois, a pró dos ideais que defendemos, com o denodo dos que são detentores de uma verdade natural. (Boletim de Eugenia, 1933, n. 39)

Prossegue Octavio Domingues com críticas positivas e negativas aos ante-projetos dos partidos P.R.P. (Partido Republicano Paulista) e P.D. (Partido Democrático). O primeiro, que seria mais digno de elogio, havia incluído um item em seu programa, referente à Organização Educacional, que preconizava a "organização de um plano geral para o desenvolvimento da eugenia no Brasil". O segundo partido, um tanto "mais medrosamente", havia incluído o subtítulo "Higiene Racial" e citado muito brevemente a questão dos exames pré-nupciais.

Tal inércia do poder público perante a legislação eugênica era, tanto para Kehl quanto para Domingues, o grande entrave do Brasil. Ao final de sua matéria, Domingues solta suas limalhas: 
Por aí parece haver uma vaga duvida a respeito da aplicação da eugenia entre nós brasileiros, sob o fundamento de que somos mestiços... e como tais não ha como aplicar os principios eugenicos na constituição da nossa raça. Mestiçamento de raças humanas não é sinonimo de degeneração. É antes origem e fonte de novos biotipos, entre os quais teremos aqueles capazes de uma adaptação melhor ao meio brasílico. E essa adaptação melhor da nossa raça em formação é a grande promessa da eugenia no Brasil. (Idem)

Tais exemplos elucidam as preocupações dos eugenistas brasileiros, suas primeiras ações, controvérsias e, principalmente, seu projetos: um povo sadio, belo podendo ser mestiço, para Domingues, e absolutamente não mestiços, como para Kehl , sem caracteres hereditários indesejados. Como método para alcançar tal objetivo, lutavam pela promulgação de uma legislação eugênica restritiva. As fontes sobre o eugenismo são, neste sentido, sempre voltadas para o futuro, permeadas por elementos utópicos. A não adoção da legislação direta tal qual desejam, porém, não impediu que o eugenismo se desse, na prática, por meios diversos nessa nova nação brasileira. Sobre este tópico seguem considerações adiante.

O médico e antropólogo Edgard Roquette-Pinto também foi um dos protagonistas do movimento eugenista brasileiro e demonstrou grande preocupação com a questão da mestiçagem. Ressalta-se que Kehl, Domingues e Roquette-Pinto partilhavam de teorias semelhantes acerca da hereditariedade - baseadas, sobretudo, naquilo que os geneticistas e eugenistas passaram a chamar de "genética mendeliana" 37 , mesmo que à revelia do trabalho de Mendel- mas divergiam quanto à sua aplicação e quanto às características que seriam positivas ou negativas. Neste ponto faz-se interessante notar que Roquette-Pinto assumiu um posicionamento mais ponderado perante a eugenia, atentando para o fato de

\footnotetext{
${ }^{37}$ As críticas à apropriação das leis de Mendel pela Genética baseiam-se em artigos do filósofo Pablo Lorenzano. Cita-se aqui o artigo "Leyes fundamentales, refiniamentos y especializaciones: del 'mendelismo' a la 'teoria del gen "', disponível em seu blog pessoal: <www.plorenzano.wordpress.com>.
} 
que os humanos possuem suas especificidades e, portanto, não são passíveis de estudos metodologicamente idênticos aos da zoologia. Bem como atentou para a existência de paixões e confusões no uso dos princípios eugenistas.

Mas foram ponderações e críticas acerca da mestiçagem não ser um fator de denegeração que marcaram o embate entre Roquette e Kehl no $1^{\circ}$ Congresso Brasileiro de Eugenia, tal como bem mostra a tese Em busca do Brasil: Edgard Roquette-Pinto e o retrato antropológico brasileiro (1905-1935), de Vanderlei Sebastião de Souza:

\begin{abstract}
Na própria conferência que apresentara durante o Congresso de 1929, Roquette Pinto firmara sua posição ao lado dos principais defensores da eugenia mendeliana, como Charles Davenport e Eugen Fischer. Contudo, ao contrário deles, utilizava-se da própria eugenia mendeliana para demonstrar que, no caso da população mestiça brasileira, nada em sua constituição genética denunciava sinal de degeneração. Os problemas que impediam o progresso do país e o melhoramento do aspecto físico e mental de parte da sua população não estariam relacionados à miscigenação, nem à herança biológica, mas sim à desorganização da política nacional, à falta de instrução e saúde. (SOUZA, 2011, p. 378)
\end{abstract}

Tais exemplos elucidam as preocupações dos eugenistas brasileiros, suas primeiras ações, controvérsias e, principalmente, seu projetos: um povo sadio - podendo ser mestiço, para Domingues; absolutamente não mestiços e sem caracteres indesejados, para Kehl; bem como geneticamente bons e vítimas da má condução sociopolítica, como para Roquette-Pinto .

Ainda sobre a mestiçagem, a antropóloga Lilia Moritz Schwarcz em sua obra $O$ Espetáculo das Raças: cientistas, instituições e questão racial no Brasil (1870-1930) destaca a importância das acaloradas controvérsias que foram imagem das transformações sociais e intelectuais do período, fruto das vertiginosas desigualdades que configuravam - e ainda o fazem - forte aspecto da identidade nacional. Pelas palavras da autora: 
uma nação em termos biológicos, regular sua reprodução, estimar uma futura homogeneidade. No entanto, apesar de "interessante" e particular, a constatação de que essa era uma "nação mestiça" gerava novos dilemas para os cientistas brasileiros. Apontava para a defasagem existente entre as teorias deterministas que chegavam de fora quando pensadas em função da "realidade mestiça de dentro", ou, melhor dizendo, revelava a rigidez da teoria quando o objeto em questão era o contexto local. Assim, se o conjunto dos modelos evolucionistas levava a crer que o progresso e a civilização eram inevitáveis, concluía também que a mistura de espécies heterogêneas era sempre um erro, que gerava não só a degeneração do indivíduo como de toda a coletividade. (MORITZ, 1993, p. 314)

Quando destes primeiros passos do movimento internacional da campanha eugenista, o Brasil vivia suas primeiras décadas republicanas, portanto, via-se como país em formação. O contexto de formação da república criou o este anseio pela formação da nacionalidade brasileira e, diante disto, o eugenismo adquiriu especial importância. O campo de discussões nacionalistas da primeira metade do século XX no Brasil é, como brevemente demonstra o debate entre Kehl e Domingues, multiparadigmático: entre a exaltação ou condenação da mestiçagem, a interferência ou não do Estado em prol do "branqueamento" da população e as propostas inúmeras acerca dos rumos a serem tomados, havia o consenso de que era preciso intervir para a regeneração do povo brasileiro, que estaria, em linhas gerais, moralmente e fisicamente degenerado. Esta intervenção poderia dar-se por orientações eugenistas, evitando a existência dos degenerados, ou sanitarista/higienista, cuidando para a melhora dos meios de existência e dos tratamentos cabíveis, ou mesmo pela união das duas vertentes, cujas fronteiras não são bem delimitadas e foram - ainda o são - fruto de controvérsias.

A obra Quem é bom já nasce feito: sanitarismo e eugenia no Brasil, do historiador André Mota elucida aproximações e distanciamentos entre os campos do sanitarismo e da eugenia, sendo que o primeiro pressupunha intervenções em prol da melhora dos meios - mesmo que pautadas por normas muito específicas - e o segundo considerava que estas 
jamais bastariam, já que a força imbatível da hereditariedade a todos subjugava. Pelas colocações esclarecedoras de André Mota:

O Brasil era tido, por alguns analistas, como o grande erro de Deus, um país cujos males alguns atribuíam à terra, outros à raça, e os mais extremados a ambas as coisas. O solo era pobre, o clima inóspito, a natureza traiçoeira. Nesse ambiente ingrato, o homem padecia, mergulhado na indolência e na tristeza. Nada produzira e nada produziria. Contrastava, com essa auto-imagem estéril, a visão idílica e romântica daqueles que viam no país a nova Canaã, que deveria ser erguida com formosíssimos jardins sempre em festa, onde veraneava um povo sadio e inteligente. Para esses, a terra era boa e, sob um céu risonho e azul, sulcavam-se remansosos rios que, de momento a momento, se despenhavam em cataratas prodigiosas, ou através de várzeas ferosíssimas enfeitadas de matas, abrindo suas margens para suspender, no dorso tranquilo, as embarcações que levavam o pão ou o livro de cidade em cidade. (MOTA, 2003, 19-20)

Em linhas gerais, caberia aos eugenistas, sanitaristas e higienistas - e entre essas áreas de atuação havia muitos nexos - contribuir para a construção da identidade brasileira. Diante desta questão, havia a possibilidade de intervir para a criação de uma dada estirpe. Se a pluralidade fenotípica do brasileiro permitia possibilidades diversas, é certo que a influência maior - pelo menos discursiva - era exercida por aqueles que tinham como ideal eugênico o biótipo europeu germânico - bem como tinham como ideal seus "valores disciplinares e morais", pois a eugenia, para além das questões físicas, preocupava-se também com as faculdades mentais e a moralidade ${ }^{38}$. Orientada por este juízo, constituiu-se a ala principal do movimento eugenista no Brasil, cujos membros, em

\footnotetext{
${ }^{38}$ Sobre os nexos e controvérsias entre sanitaristas e eugenistas, há interessantes comentários tecidos por Mariza Côrrea acerca da obra Hora da Eugenia: raça, gênero e nação na América Latina, de Nancy Stepan. Côrrea chama a atenção para a necessidade de se complexificar a história da eugenia na América Latina, incluindo abordagens, resistências e especificidades regionais, bem como os distanciamentos entre os discursos - geralmente, acalorados e mais radicais - e as práticas que, ainda de acordo com as especificidades regionais, por vezes se apresentaram diferentes dos projetos. Tal debate pode ser encontrado em CORREA, Mariza. Eugenia no calor da hora. História, Ciências, Saúde- Manguinhos. Vol. 13. ํำ 2. Rio de Janeiro, apr-jun 2006.2 Disponível em: $<$ http://www.scielo.br/scielo.php?script=sci arttext\&pid=S0104-59702006000200016>. Acesso em: ago. 2014.
} 
significativa parte, eram médicos:

A ação saneadora esperava criar a possibilidade de rever o tema da formação dos brasileiros e todas as ambiguidades que cercavam essa discussão. A observação pormenorizada dos níveis de educação, das condições de saúde e moradia, dos costumes e das manifestações culturais levaria ao suposto conhecimento empírico desse povo. Eis porque os médicos da época aceitariam a missão de restaurar a sociedade avariada: só eles poderiam desvendar - e combater - as causas que tornavam o progresso nacional incerto. (MOTA, 2003, p. 41)

O historiador Thomas Skidmore em sua pioneira obra Preto no Branco: raça e nacionalidade no pensamento brasileiro (1870-1930) também tratou com maestria das principais escolas e vertentes intelectuais que constituíram os debates acerca dos rumos que deveriam ser tomados rumo ao progresso do país. Iniciando pelo pensamento dos abolicionistas, pondera:

Como se não bastasse o desafio de transformar sua sociedade, os brasileiros ainda tinham de enfrentar a possibilidade de que seu ideário fosse irrelevante. Seria verdade que o progresso moderno se destinava apenas a homens brancos de zonas temperadas? (SKIDMORE, 2012, p. 32)

Para compreender este anseio pela modernização, o historiador percorre teorias diversas, daquelas que exaltavam o indianismo platônico como "moda social e intelectual entre os membros da elite" aos ímpetos abolicionistas que traziam em seu cerne os ideais de branqueamento, apesar da aparente contradição. No âmbito das ciências, tais ímpetos modernizantes conviviam em harmonia com o positivismo, sendo as doutrinas de Auguste Comte, pelas leituras que delas faziam, tidas como a melhor aplicação lógica da ciência nas sociedades que a produzem. O positivismo, afirma, "atraía aqueles membros da elite que ansiavam por desenvolvimento econômico, mas sem mudança social" (Idem, p. 48).

Havia muitos nexos entre as sedutoras e autoritárias doutrinas positivistas - que 
ganharam campo a partir da década de 1860 - e as teorias eugenistas que ganharam força algumas décadas depois, no início do século XX. Sobre esta influência, elucida:

Entusiastas posteriores do positivismo muitas vezes exageraram o impacto da doutrina positivista, mas não se pode contestar a grande influência do positivismo filosófico na formação de engenheiros, oficiais do Exército e médicos a partir da década de 1870. Esses homens foram expostas a um dogma científico que desafiava toda a estrutura de privilégios existente na política (a monarquia), na economia (a escravidão), na religião (uma igreja cristã oficial) e na educação (a negligência das ciências e o patrocínio oficial da educação religiosa). (Ibidem, p. 49)

Os atributos da modernização, do progresso e do ímpeto reformista constituem importantes elementos para a compreensão dos jovens intelectuais que pensavam os rumos do país, que se viam, sobretudo, como arautos das negações e injustiças do sistema vigente, propondo o novo. Mesmo que, em reflexão posterior, este elemento novo não pareça socialmente revolucionário. O eugenismo, assim, também esteve relacionado aos ímpetos críticos de alguns novos intelectuais da República em relação ao regime que consideravam ultrapassado e de privilégios injustos. Viam-se como guias de uma nova perspectiva, tal como chamava Kehl, a bioperspectiva, que orientava um olhar específico para a existência e para o tempo. Aqui se considera que o elemento revolucionário que propunham, no entanto, baseava-se em aspectos tão autoritários e restritivos quanto aquilo que desejavam combater:

As novas ideologias de progresso e de ciência eram um remédio forte e atraente para espíritos jovens numa nação cuja estrutura social e herança cultural não poderiam ser mais diferentes do panorama de progresso material da Europa ocidental e na América do Norte. Em 1878, Pereira Barreto, o positivista paulista, assim escreveu a José Bonifácio, o Moço, um dos patriarcas políticos: V. Ex. ${ }^{a}$ tem vivido nas nuvens, tem aderido a elas, e tem-se descuidado dos negócios da terra. A sua geração foi toda de literatura e imaginação: a nossa é toda de ciência e razão. Outros tempos, outros temperamentos. (Ibidem) 


\section{5 "A ciência precipita sua marcha"}

Nas "Preliminares" de sua obra Catecismo para adultos: ciência e moral eugênicas publicada em 1942, Kehl afirma que as primeiras quatro décadas do século XX - período do qual participou ativamente - foram palco de um vertiginoso progresso das ciências biológicas. Os métodos haviam tomado corpo, construído bases sólidas e comprovações quase irrefutáveis. Dali a alguns anos, os "jatos de luz" lançados pela ciência atingiram até a grande massa, "para o gaudio pouco exigente de sua existência medíocre" (KEHL, 1942, p.13). Estas transformações ainda se dariam em processo de aceleração: quanto mais o tempo avançava, menores os intervalos entre os progressos científicos. Diante disso, questiona: "Que preconceitos doutrinários e dogmáticos resistirão a mais quarenta anos nesta marcha acelerada?" (Idem).

Para acompanhar o ritmo das transformações - ou, pelos olhares próprios, do progresso - os primeiros eugenistas brasileiros protagonizaram uma profusão de estudos, formação de sociedades, congressos e publicações sobre o tema. Era necessário o estabelecimento de uma rede de relações que englobasse desde juristas, engenheiros e educadores a profissionais da saúde e políticos, objetivando a propaganda e conscientização vertical, que atingiriam do poder público à "massa".

Pelas palavras do próprio Kehl:

Foi em 1912, quando se reuniu em Londres o primeiro Congresso Internacional de Eugenia, convocado pela Universidade dessa Capital, que tivemos contato inicial com a sciencia de Galton. Preoccupavam-nos, então, certos pontos da complexa e debatida questão da hereditariedade, que estudávamos em trabalhos recebidos de Gallardo, Sergi, Apert, Hirsch e outros. Nos centros adeantados cuidava-se, nessa época, sobretudo na Inglaterra e Estados Unidos, de dar expansão aos ideaes da melhoria racial, fazendo-se, para isso, intensa propaganda nas universidades e pelos jornaes. (KEHL, 1929, p.15) 
Souza Lima (1842-1921) ${ }^{39}$ é considerado o precursor na tentativa de implantar medidas eugênicas no Brasil, por sua conferência proferida na Academia Nacional de Medicina, em 1897, intitulada Exame pré-nupcial. Na ocasião, propôs uma legislação que instituísse o exame pré-nupcial obrigatório e o impedimento do casamento entre portadores de sífilis e tuberculose. Posteriormente, conferências e publicações acadêmicas com o tema começam a aparecer: em 1912, Horácio de Carvalho publica artigo no Estado de São Paulo apresentando noções sobre o desenvolvimento da campanha na Inglaterra; em 1913 o médico Alfredo Ferreira de Magalhães, docente da Faculdade de Medicina da Bahia e diretor do Instituto de Proteção e Assistência à Infância, proferiu a conferência Pró-Eugenismo, em Salvador; em 1914, sob orientação do professor Miguel Couto, o médico Alexandre Tepedino apresenta a tese Eugenía à Academia de Medicina do Rio de Janeiro e, no mesmo ano, o filólogo João Ribeiro, membro da Academia Brasileira de Letras, consolidou o termo eugenia, como julgou ser a melhor tradução para o português. Outros artigos, como os de autoria de Erasmo Braga ou o opúsculo "Melhoremos nossa raça", publicado em 1916 pelo eugenista inglês então residente no Brasil Charles W. Arminstrong, fizeram parte desta fase inicial.

No ano de 1917, Renato Kehl proferiu uma conferência na Associação Cristã de Moços de São Paulo intitulada "Eugenia". Publicada no Jornal do Commercio e, posteriormente nos Annaes de Eugenia, o conteúdo da conferência atraiu a atenção de muitos e despertou no próprio o propósito de criar um projeto efetivo. É consenso entre

\footnotetext{
${ }^{39}$ Agostinho José de Souza Lima, médico formado pela Faculdade de Medicina do Rio de Janeiro em 1863. Ocupou a posição de patrono da cadeira número 3 da Academia Nacional de Medicina do Rio de Janeiro. Ministrou cursos de medicina legal e toxicologia na Faculdade de Medicina do Rio de Janeiro e na Faculdade de Direito. Destaca-se, ainda, entre seus cargos, o de diretor da instituição de Higiene e Assistência Pública Municipal, em 1894, no mesmo estado. Renato Kehl destacava seu pioneirismo na defesa do eugenismo.
} 
os pesquisadores do movimento brasileiro que a atuação de Kehl, por sua intensidade, é um marco na propaganda eugenista brasileira. Nas palavras de Vanderlei Sebastião de Souza: "Contudo, a hora e a vez da eugenia no Brasil chegou somente no final da década de 1910, quando o médico e eugenista Renato Kehl iniciou uma grande campanha de divulgação da eugenia no meio médico e intelectual brasileiro" (SOUZA, 2006, p. 31).

O primeiro passo seria a criação de uma associação formada por profissionais diversos que deveriam reunir-se para discutir questões nacionais a partir do viés biossocial. No dia 15 de janeiro de 1918, a Sesp (Sociedade Eugênica de São Paulo) é inaugurada, com apoio de Arnaldo Vieira de Carvalho, como presidente, Olegário de Moura como vice-presidente, Renato Kehl como secretário geral, Arthur Neiva, Franco da Rocha e Rubião Meira como conselheiros consultivos e Belisário Penna, Amâncio de Carvalho e Agostinho de Souza Lima como presidentes honorários. Sobre a fundação nos conta Kehl que:

\begin{abstract}
A 15 de Janeiro do anno seguinte fundamos, sob o patrocínio do Prof. Arnaldo Vieira de Carvalho, então director da Faculdade de Medicina daquella Capital, a Sociedade Eugenica de S. Paulo, a primeira associação deste gênero criada na America do Sul, cuja solemnidade inaugural teve logar no salão nobre da Santa Casa de Misericórdia, onde se realizavam as sessões da Sociedade de Medicina e Cirurgia, achando-se presente grande numero de médicos da Capital e do interior de S. Paulo. A sua instalação despertou grande interesse não só do Brasil, como na America Latina e Europa. (KEHL, 1929, p. 16)
\end{abstract}

A Sesp angariou inicialmente 140 sócios oriundos de setores diversos, interessados na implantação das soluções eugênicas no país. Sua extinção se deu em 1920, após a morte de Arnaldo Vieira e a transferência de Kehl para o Rio de Janeiro ${ }^{40}$, onde

\footnotetext{
40 As discussões eugenistas no Rio de Janeiro estavam especialmente concentradas na psiquiatria. Em 1922 é fundada a Liga Brasileira de Higiene Mental, reunindo profissionais de setores diversos, aos moldes da
} 
onze anos mais tarde fundou a Comissão Central Brasileira de Eugenia ${ }^{41}$. Em janeiro de 1929, o Boletim de Eugenia passa a ser editado, sob "direção e propriedade" de Kehl' Neste mesmo ano é organizado o $1^{\circ}$ Congresso Brasileiro de Eugenia. Entre o ano de criação de Sesp e a nova profusão de atividades, sobretudo a partir de 1929, a historiadora Pietra Diwan lança o questionamento:

\begin{abstract}
Teria tido alguma influência na paralisação das atividades da Sesp a mudança de Renato Kehl para o Rio de Janeiro nesse mesmo ano, por conta de seu casamento com Eunice Penna, filha de Belisário Penna? Ou será que a elite paulista não tinha um real interesse no tema, sendo a Sociedade somente um pretexto para reuniões periódicas para o debate de um tema 'na moda', a eugenia? Talvez mereça ênfase o fato de Renato Kehl ser o incentivador e estimulador do debate sobre a eugenia, o que despertava o interesse de muitos membros da elite paulista, mas não o suficiente para fazê-los 'tomar as rédeas' nos rumos da Sesp. Isso porque alguns dos membros da Sociedade, após mais de uma década, migraram para a Comissão Central Brasileira de Eugenia, sediada no Rio de Janeiro e dirigida por Kehl. (DIWAN, 2007, p. 67)
\end{abstract}

Sobre a extinção da Sesp, Kehl denunciava a falta de entusiasmo que a paralisara.

Mas se a crítica era indiretamente direcionada ao legislativo - que não acompanhava o ritmo de decretos propostos pela Sesp, talvez pelo incômodo que a forte polêmica causaria - é certo que foi aclamada pela imprensa, da qual recebeu comentários elogiosos. Comentários estes, aliás, frequentemente recebidos Renato Kehl, cujas menções encontradas em jornais das décadas de 20, 30 e 40 são abundantes. Ainda sobre os objetivos da Sesp, estes estavam sintetizados em seu estatuto:

Sesp e de outras sociedades que se formavam pelo mundo.

${ }^{41}$ Em publicação no $27^{\circ}$ Boletim de Eugenia, Kehl esclarece que a CCBE objetivava a colaboração com projetos governamentais de caráter eugênico, bem como sua divulgação.

${ }^{42}$ A publicação, inicialmente, seria propaganda de um futuro Instituto Brasileiro de Eugenia, sendo este um projeto de Kehl que não logrou. A partir de junho de 1929, passa a ser uma separada da revista Medicamenta, como frequência mensal. Em 1932, passa a ser editada em Piracicaba, com apoio de professores da Escola Superior de Agricultura Luiz de Queiroz, em frequência trimestral, como órgão da Comissão Central Brasileira de Eugenia. 
...estudar as leis da hereditariedade; a regulamentação do meretrício, dos casamentos e da imigração; as técnicas de esterilização; o exame pré-nupcial; a divulgação da eugenia e o estudo e aplicação das questões relativas à influência do meio, do estado econômico, da legislação, dos costumes, do valor das gerações sucessivas e sobre aptidões físicas, intelectuais e morais. (ANNAES DE EUGENIA, 1919)

Pelo estatuto da Sesp constata-se que havia, portanto, certos embates e complementaridades entre a eugenia e o sanistarismo e higienismo no Brasil, como supracitado. Vale ressaltar que no mesmo ano de criação da Sociedade, em 1918, houve a fundação da Liga Pró-Saneamento do Brasil (LPSB), com participação de Belisário Penna, Monteiro Lobato, Vital Brasil, Arthur Neiva, Carlos Chagas, entre outros sócios, estando dentre eles o próprio Kehl. O próprio sogro de Kehl, Belisário Penna, denunciara - em relatórios sobre as expedições aos interiores do país - o descompasso entre o valor físico dos trabalhadores brasileiros e as condições insalubres nas quais viviam (MOTA, 2003). Apesar de integrar o movimento eugenista, Penna demonstra, portanto, a convicção de que o meio de existência poderia influenciar as habilidades humanas.

Ainda sobre o fim da SESP, pondera Vanderlei de Souza:

No entanto, apesar da Sociedade ter encerrado suas atividades dois anos após a sua fundação, ao longo dos anos 1920 as discussões sobre eugenia ainda encontraram espaços de debates em São Paulo, como é possível perceber através da Revista do Brasil que, editada na capital paulista, continuou publicando artigos, resenhas e comentários relacionados a eugenia. As teses acadêmicas defendidas pela Faculdade de Medicina de São Paulo também continuaram aparecendo neste período, principalmente através da vinculação da eugenia com a educação, imigração e higiene. (SOUZA, 2006, p. 39)

A cada debate configurou-se, assim, a eugenia como pano de fundo das discussões sobre aquilo que se deveria vir a ser. Para a instituição de um Estado cientificamente 
orientado, fazia-se necessária uma marcha acelerada, impulsionada por esses intelectuais militantes. Os esforços catequistas não foram medidos e as publicações, neste caso, adquiriam especial importância. 


\title{
Capítulo 4: Pelo progresso, contra a decadência: o túmulo da anormalidade.
}

\subsection{A História regida pelas células germinais}

Renato Kehl foi leitor profícuo e divulgador de Francis Galton, cujo pensamento tornou-se sua matriz teórica e a quem não poupou admiração e comentários elogiosos. Como epígrafe de sua importante obra Lições de Eugenia ${ }^{43}$ (1929), afirmou Kehl que “A sciencia de Galton é o pedestal da religião que tem por escopo a regeneração integral da humanidade" (KEHL, 1929, contracapa). Sobre os ímpetos laudatórios, Souza cita o artigo "Galton: sábio construtor", publicado no Jornal Correio da Manhã em 07 de fevereiro de 1930 e também no $20^{\circ}$ volume do periódico Boletim de Eugenia:

\begin{abstract}
Em homenagem a esse cientista, considerado por ele como um "verdadeiro humanista", Renato Kehl escreveu vários artigos, memórias, notas e comentários biográficos durante as décadas de 1920 a 1930, muitos, inclusive, publicados em jornais e revistas de grande circulação nacional. Nas palavras deste autor, a "inteligência rara" e o "idealismo construtor" de Francis Galton tinham origens na própria formação hereditária de sua família. Bisneto de Erasmo Darwin e primo de Charles Darwin, Kehl acreditava que a "ilustre estirpe" da qual Galton tinha nascido não o permitiu fugir dos "bons desígnios que o fizeram o patrono de uma das mais belas estirpes destes últimos séculos". Kehl destaca que o "grande pai da eugenia" era um "tipo perfeito e equilibrado de homem: fisicamente, robusto; psiquicamente, um superior; moralmente, um tipo exemplar", o que teria possibilitado que suas obras se destacassem no cenário científico mundial. (SOUZA, 2006, p. 69)
\end{abstract}

\footnotetext{
${ }^{43}$ A obra Lições de Eugenia foi publicada por Kehl pouco após seu retorno da Europa, onde teve contato com novas ideias eugenistas de teor mais radical, sobretudo, na Alemanha nazista, onde esteve por conta de seu trabalho como diretor na empresa Bayer. Publicado pela renomada Editoria Livraria Francisco Alves, a obra foi lançada pouco antes do $1^{\circ}$ Congresso Brasileiro de Eugenia, tornando-se tão polêmica quanto reverenciada por intelectuais diversos. Em sua dissertação de mestrado, Souza (2006) procura demonstrar que Lições marca o teor eugenista restritivo mais radical adotado por Kehl após o contato com as teorias alemãs e norte-americanas, cujas propostas visavam o controle e impedimento da reprodução humana e, por vezes, a eutanásia.
} 


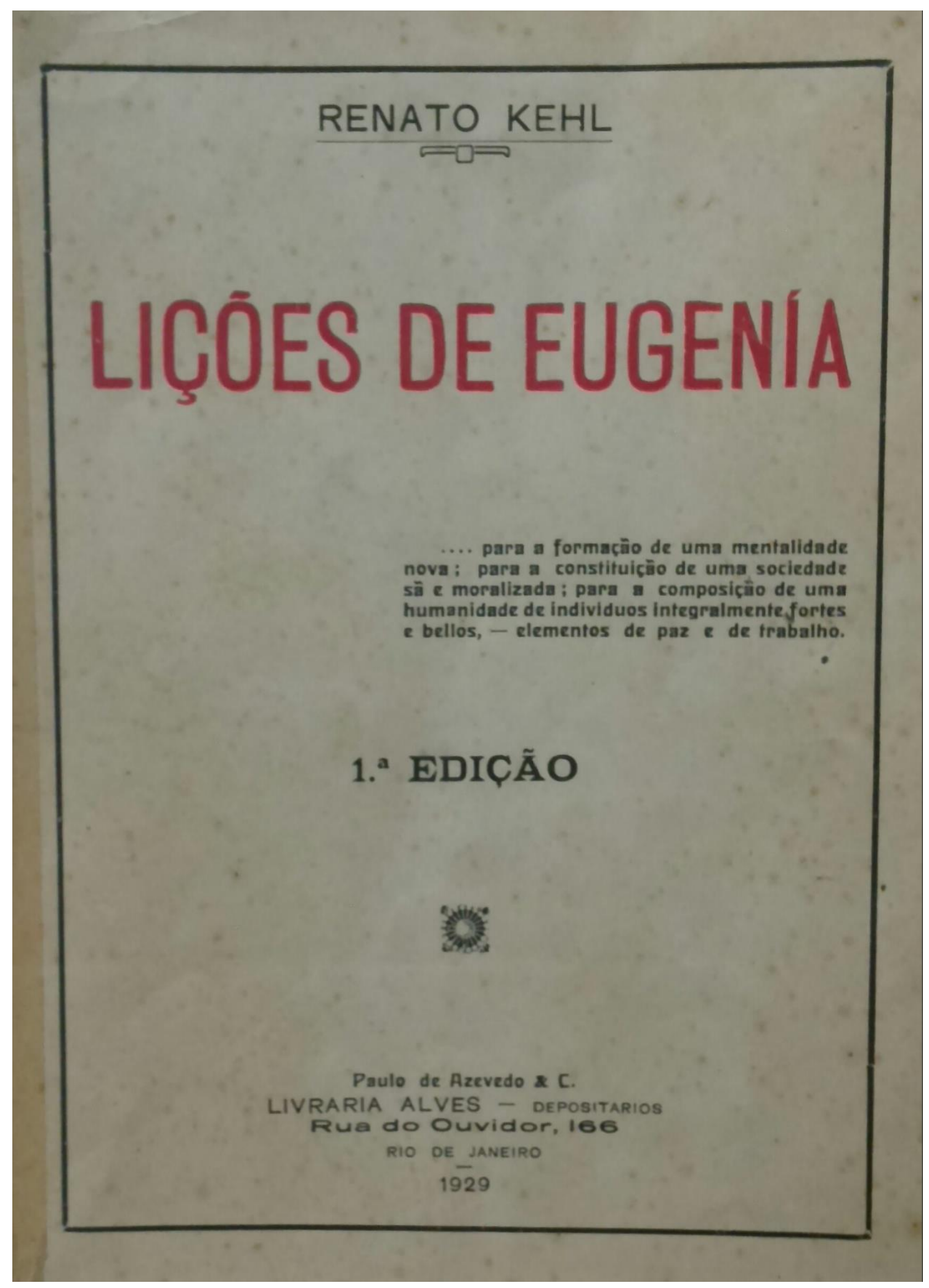

Figura 13. Reprodução da capa da obra Lições de Eugenia (1929)

Um dos pilares desta ciência galtoniana se dava pela interpretação de aspectos 
históricos das sociedades e de seus indivíduos, cujos sucessos ou fracassos socioeconômicos identificados eram, em última instância, provas cabais do valor de seus caracteres biológicos predominantes, de suas habilidades adaptativas e capacidade evolutiva. Nota-se que para as teorias eugenistas, além das questões adaptativas, as noções de melhoramento e elevação das capacidades individuais e, consequentemente, de uma dada noção de progresso eram intrínsecas a ideia de evolução. Nas palavras de Kehl, a orientação eugênica da evolução tinha a finalidade de "aperfeiçoar incessantemente a espécie humana", denotando, portanto, a noção - também missão - da perfectibilidade.

O pensamento eugenista tomava para si e construía uma concepção específica do passado e da História, pautada principalmente pelas leis da Biologia. Não à toa, Kehl dedica a primeira das doze lições do seu Lições de Eugenia às bases históricas da teoria, especificamente, à visão idealizada dos gregos, cujas sementes germinais pareciam dotadas de virtudes historicamente invariáveis e inabaláveis:

\begin{abstract}
Admittem certos historiadores que a Grecia deve ao oriente os factores de sua cultura material, religiosa, philosophica e artística; inspirando-se na civilização brahamanica, criou ella a inegualavel posição de destaque conservada durante muitos séculos em todos os domínios do saber humano. Os gregos viam, ouviam e depois adaptavam o que aprendiam, imprimindo um caracter brilhante e particular, sem nunca se deixar absorver por influencias estranhas, como sóe acontecer á generalidade dos povos. (KEHL, 1929, p. 07)
\end{abstract}

As inspirações e influências do bramanismo deviam seu florescimento ao brilhantismo transformador dos gregos que, por excelência, jamais se deixavam contaminar:

Tão solido era o caracter dos helenos que o ascetismo e o mysticismo contagiosos dos indianos não os desviaram da norma traçada atravez das gerações. Amavam a poesia sem se deixar impregnar pelo espiritualismo inebriante; lançavam olhares embevecidos ao Olimpo, residência dos deuses, sem se descuidar da face real da vida terrena; e enquanto os indianos consideravam a vida uma expiação, os gregos amavam-n'a, cada vez mais, sem consideral-a daquele modo pessimista Dentro deste critério, fundado no 
desprezo do corpo e na concentração espiritual vivia o povo indiano, enquanto o grego divinizava a robustez e a beleza nos festins alegres das palestras. Assim, num rápido confronto, se distingue a concepção moral grega da brahamanica; a primeira de almas fortes no amôr á vida; a segunda de almas que se extasiam, contemplativamente, ao mystico murmúrio das aguas do Ganges. (idem, p. 08)

Essas supostas vantagens que os gregos apresentavam perante os indianos não havia sido conquistadas ao acaso. Ao não se ligarem de maneira significativa àquilo que classifica de inebriante misticismo, e sim à racionalidade terrena, teriam os gregos permanecido livres para tomar atitudes em prol do aperfeiçoamento duradouro de suas células germinais:

Foi o povo grego, particularmente o da Laconia, assim inspirado, que mais se esforçou pelo aperfeiçoamento humano; e nos fastos da gloriosa Sparta houve uma época em que dentre os elevados intuitos nacionalistas, sobresahia o da melhoria progressiva da raça, no sentido de transformal-a em uma elite homogênea de homens robustos, bellos e inteligentes. (Idem)

Estes intuitos nacionalistas de melhoria progressiva da raça concretizavam-se em métodos específicos:

Para alcançar tal desideratum, quasi utopico naquelas eras, em que a sciencia iniciava os passos, houve espíritos vigorosos e clarividentes que não hesitaram em estabelecer leis severas, mesmo crueis, para garantir o futuro do povo impar, como o grego, cujas gloriosas tradições se acham impressas, indelevelmente, no seu bello passado milenário. (Idem)

\section{Dentre os espíritos “vigorosos e clarividentes" destacava-se Licurgo ${ }^{44}$, o lendário}

legislador da pólis de Esparta eu havia promovido uma definitiva obra selecionadora:

Lycurgo, legislador de Sparta, foi o campeão da obra selecionadora, a avaliar pelo seu capricho obstinado e selvagem, porque determinava fossem lançadas ao Eurotas as pobres e infelizes crianças, cuja sorte lhes ditara a má sina de

\footnotetext{
${ }^{44}$ A vida do legislador Licurgo, sobre a qual há controvérsias na historiografia, é conhecida, principalmente, pela obra dos pensadores Xenofonte (A República dos Lacedemônios) e Plutarco (A Vida de Licurgo), que se dedicaram aos aspectos míticos e históricos do legislador espartano, bem como à Rhetra, conjunto de leis por ele criado e ao qual se refere Kehl na referida passagem (SILVEIRA, 2009).
} 
virem ao mundo rachiticas e degeneradas. Esse tyranno que viveu no $9^{\circ}$ século antes da era cristã, não concebia a existência de entes cacogenicos que viessem perpetuar a sua monstruosidade, fealdade, ou doença. O Eurotas era o remedio radical contra a degeneração, - o tumulo da anormalidade. (Idem)

Kehl prossegue sua interpretação sobre as ações - por vezes, sabidamente assassinas- do legislador tecendo apontamentos e sutis adjetivos elogiosos que condizem, como veremos adiante, com sua visão sobre seu tempo presente:

\begin{abstract}
Afim de não serem alterados os costumes pátrios, considerava-se perigo o contacto com estrangeiros. Estaleceu-se, assim, completo isolamento no sentido de evitar que o povo espartano fosse contaminado pelo amôr das riquezas, do luxo e das orgias. Lycurgo, sapiente e precavido, para manter o prestígio moral e pshysico da raça, determinou, ainda, a expulsão dos estrangeiros perniciosos, aplicando a "xenelasia", sobretudo aos atenienses, cujos princípios julgava attentatorios ao caracter e aos interesses dóricos. Esse critério selecionador foi praticado pelo povo mais bello e robusto de todas as eras. (Idem. p. 09)
\end{abstract}

Alguns séculos adiante, no tempo de Platão, nota Kehl que os gregos adotariam outros "métodos aphuradores" perante a necessidade de se evitar a degeneração. Para além da morte de recém-nascidos e da proteção contra os estrangeiros, passariam os gregos a se preocupar- iluminados por Platão- com as restrições reprodutivas. Para elucidar Kehl transcreve o célebre diálogo entre Sócrates e Glauco, citado por Platão em A República, quando Sócrates ensinaria a Glauco que a superioridade existente entre animais de cria pode ser transposta aos humanos; uma vez que fosse cuidado que aqueles em boa idade e melhores "prendados se reproduzissem".

Em sucinto avanço cronológico afirma Kehl que durante a Idade Média e Idade Moderna houve sério descaso para com a perfectibilidade humana tal qual preconizaram os gregos. Mesmo na era de Luís XIV, o "rei-sol”, não teria havido cuidado nem com a higiene, tampouco com o importante depuramento humano. Assim seguiram-se as trevas até tempos recentes para o autor, quando Francis Galton teria esboçado e sistematizado, 
finalmente, os ideais regeneradores (KEHL, 1929, p. 11).

A explanação de Kehl acerca destes aspectos históricos é elucidativa. Para ele, Licurgo, ao negar a vida para os seres disgênicos, teria garantido o estabelecimento do progresso biológico e social para as etapas de desenvolvimento posteriores. Abria-se espaço, assim, para que as leis biológicas da descendência se dessem sem a interferência dos mecanismos artificiais de existência que os humanos, por serem sensíveis e emotivos, teimavam em criar.

No pequeno livro Por que sou eugenista, publicado em comemoração aos vinte anos da campanha eugênica- oito anos após o Lições- Kehl reafirma suas convicções históricas ao afirmar, no ítem "Degeneração e Esterilização", que haveria ideias simples, de fácil compreensão e úteis para o aperfeiçoamento dos indivíduos da nação brasileira. Estas, no entanto, custariam a ser admitidas por conta daquilo que caracteriza como “imbecilidade social”. Por suas próprias palavras:

Há ideias simples e uteis que, não obstante de fácil compreensão, custam a ser admitidas, porque esbarram nos entulhos em que se misturam indiferença ou cepticismo, rotina, preconceito e, - por que não dizer? - imbecilidade social. Cinco e meio séculos antes da era atual, Teognis escrevia: "Quando se trata de porcos e de cavalos, aplicamos regras razoáveis, no sentido de encontrar, a todo custo, raças sem vícios nem defeitos, para com elas obter produtos sãos e vigorosos. Vemos, entretanto, que em relação aos nossos semelhantes, as coisas se passam de outro modo; não é, pois, para admirar que a espécie humana degenere cada vez mais, quanto á forma, ao espirito e aos costumes". Algum tempo depois, ou sejam três e meio séculos antes da era presente, Platão expôs na "A República", ideias sobre o mesmo assunto, na palestra simulada entre Socrates e Glauco. Rematando-as com as seguintes palavras: - "Grandes deuses, se o mesmo se praticasse com os homens, outros seriam os espécimes com que contaríamos! Escolhendo os mais indicados para dar filhos são, vigorosos, inteligentes e capazes, bem diverso seria o valor físico e moral da espécie humana”. (KEHL, 1937, p. 68) 


\section{RENATO KEHL \\ PRESIDENTE DA COMISSÃO CENTRAL}

BRASILEIRA DE EUGENIA

\section{Dor que sow \\ Eugenista}

20 anos de Campanha

Eugenica

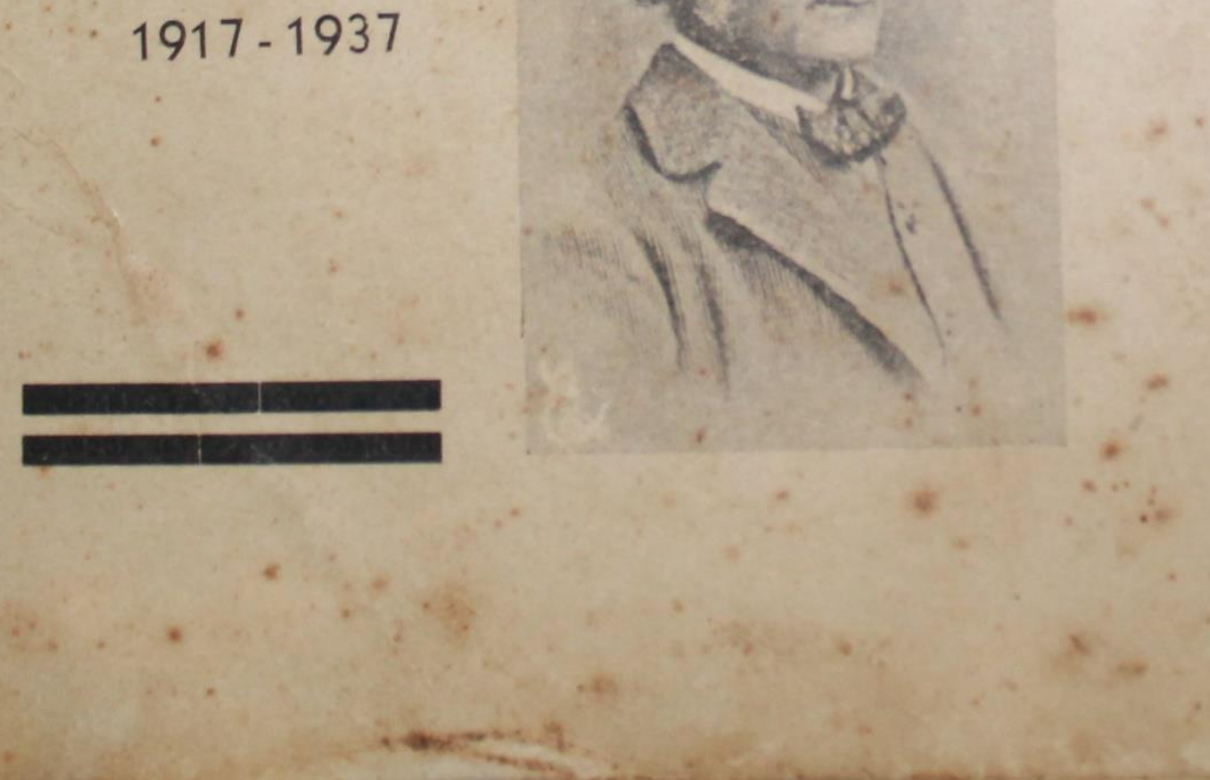

c.

Figura 14. Reprodução da capa da obra Por que sou eugenista (1937) 
Tais explicações de Kehl acerca do passado histórico trazem em seu cerne a concepção de mundo presente e suas representações do futuro que, assim, oscilavam entre possíveis estados de plena saúde, prosperidade e felicidade ou, caso o descuido eugênico permanecesse, em plena desgraça, dada pela proliferação dos degenerados. Os degenerados, como mostravam as diversas estatísticas feitas pelos eugenistas, se reproduziam em maior número do que os eugênicos, determinando a qualidade de uma nação. As leis que regeriam as sociedades e a história seriam, em primeira instância, as leis biológicas definidas a partir da ascendência ancestral. Sobre isso adverte Kehl em seu Bioperspectivas:

\begin{abstract}
Atenha-se alguns minutos a pensar no que foram os seus ascendentes. Examine, de início, a vida de seus pais; como são ou foram, fisicamente; quais os caracteres que neles mais se destacam ou se destacavam: a estatura, a corpulência, a côr dos olhos e dos cabelos. Analise, depois, mentalmente, os avós que conheceu, recordando-se de certos traços e hábitos que os personificavam. Imagine, então, como teriam sido seus bisavós, seus tataravós, e assim por diante, caindo no mundo das divagações sobre o passado longínquo em que viveram esses ancestrais da velha guarda... Lembre-se, então, que você representa um anel de uma longa cadeia hereditária; que os caracteres físicos, psíquicos e mentais que lhe são próprios, tais como o talhe, a corpulência, a cor dos cabelos e olhos, a vivacidade espiritual, as aptidões, a inteligência, foram transmitidos segundo leis fixas e que diversos caracteres, normalmente correlativos ou ligados nas linhagens puras, podem, misturando-se a linhagens bastardas ou degeneradas, formar combinações desharmônicas, dar nascimento a entes feitos, desequilibrados ou doentes; - lembre-se então que compete a cada um de nós zelar pelo nosso patrimônio, do qual somos apenas depositários efêmeros, pois que ele pertence, em última análise, a uma das muitas linhagens que constituem o gênero humano, de cuja cadeia somos simples elos. (KEHL, 1937, p. 113)
\end{abstract}

Este alerta de Kehl possuía séria justificativa científica, dada, principalmente pelo trabalho do biólogo alemão Friedrich Leopold August Weismann (1834-1914), professor da Universidade de Freiburg. Weismann propôs inovações na teoria da hereditariedade que foram inteiramente adotadas por Kehl, tal como expõe em seu Lições. Conta Kehl que Weismann, ao observar plantas e animais, notou que alguns protozoários não morriam senão acidentalmente, concluindo que a morte não seria, assim, um fenômeno geral. Tal observação teria motivado o desenvolvimento da teoria do plasma germinativo. 
Em linhas gerais, esta teoria teria como base a existência de dois tipos de plasmas celulares - esta ideia, atenta Kehl, anterior ao trabalho de Weismann: o morfoplasma e o idioplasma. O primeiro estaria nas células somáticas, enquanto o segundo, nas células reprodutoras. Esse idioplasma teria a característica peculiar de conter a totalidade dos caracteres dos grupos celulares e cromossomos determinantes, enquanto as células somáticas, formadas por morfoplasma, não teriam cromossomos com estas características. Havia, ainda, uma diferenciação principal, concluída a partir da capacidade reprodutiva dos seres unicelulares de se multiplicarem por bipartição: as gélulas germinais seriam perenes, imortais, pela sua capacidade de continuarem a viver na descendência.

Kehl apresenta os princípios gerais das ideias de Weismann:

1) Caracteres adquiridos são os que resultam das influencias externas sobre o organismo, em contraste com os que emanam da constituição da célula germinal

2) Os caracteres podem ser herdados, somente quando os seus rudimentos (Anlagen) estiveram realmente já pressentidos no plasma germinativo.

3) As modificações produzidas sobre o organismo e devidas a influencias externas, ficam a elles limitadas.

4) O mesmo facto é verdadeiro para as mutilações e para os resultados do uso e desuso das partes do corpo.

5) Taes modificações do soma (os tecidos e órgãos, distinctos das cellulas reproductoras), isto é, aquellas que são produzidas por influencias mesológicas ou pelas funcções do organismo, não podem ser transmittidas ás células germinaes. Não tem, pois, qualquer papel na transformação da espécie.

6) O único principio acceitavel para a explicação das modificações das espécies é a variação germinal directa. (KEHL, 1929, p. 63)

O plasma germinativo constituía, portanto, uma estrutura complexa e resistente que resistiria a influências externas ao longo das gerações. Tal teoria complementava de maneira importante a ideia da não influência dos fatores externos nos mecanismos da hereditariedade. E ia além: 
A idéa de Weismann da não transmissibilidade dos caracteres adquiridos soffreu criticas severas. Fez desrruir a concepção de Lamarck. Hartog, por exemplo, disse: "sem hereditariedade dos caracteres adquiridos, os homens seriam ainda protozoários", e Spencer: "ou bem há hereditariedade dos caracteres adquiridos ou bem não houve, absolutamente, evolução”. Apezar das criticas, a concepção weizmanniana da não hereditariedade dos caracteres adquiridos, ficou, pode-se dizer, de pé. (Idem, p. 66)

Afirma Kehl que Weismann teria rebatido as críticas complementando que a evolução se daria de maneira muito lenta e pela combinação entre os plasmas dos sexos opostos. A importância da teoria de weismanniana para o pensamento eugenista é, portanto, inegável, dado que a partir destas ideias a hereditariedade para a ser regida por mecanismos conversadores através de gerações sucessivas. Ideia que, somada aos postulados que conferiam poderes determinantes aos caracteres, permitiu a extração de leis sociais a partir das leis biológicas e vice-versa.

Ao referir-se especificamente ao progresso, ainda em seu Lições, Kehl afirma que os povos e indivíduos do Velho Mundo estariam sujeitos ao curso regular, regido por lei invariável, sob influência daqueles fatores resistente ao longo das gerações. Eis a lei do progresso. Pautando-se por ela, os gregos não decaíram: apenas espalharamse pelo mundo. Os europeus também não decairiam: estariam apenas trazendo seus caracteres superiores, seus virtuosos fatores invariáveis, para a América. Aparentes declínios sofridos por essas sociedades seriam, apenas, aquilo que chama de fase regressiva da evolução em espiral:

Ainda há muitos optimistas no mundo, apesar dos tempos pouco venturosos que atravessamos. Os bafejados pela visão a Leibniz não admittem o desapparecimento de um povo, como se dá com um indivíduo, que é roubado á vida pela parca impiedosa. E muito menos de um povo, como o hellenico, que se diz, geralmente, em completa retrogradação, vivendo, apenas, das tradições gloriosas do passado. Tal affirmação, dizem, é injusta e resulta do desconhecimento da lei do regresso apparente, já referida. Segundo aquelles, a Grecia não estacionou e muito menos o seu povo desappareceu ou mesmo desmereceu. Elle ausentou-se do Peloponeso; o seu sangue valoroso caldeou- 
se, transfundiu-se nas veias de outros povos, que hoje brilham. Não foram eles os cruzados da antiguidade, os desbravadores e semeadores de colonias na Europa, na Africa na Asia, colônias estas que conservam, ainda, traços evidentes de origem grega? (KEHL, 1929, p. 25)

E assim, devidamente orientado pela lei do regresso aparente, apresenta provas históricas e presentes de que os helenos não decairiam:

Pelo exposto concluímos que a Grecia não decahiu e, do mesmo modo, que o Occidente não está em decadência próxima nem remota. Atravessa uma phase regressiva em espiral; ou, em outros termos, atravessa uma grande crise. A civilização move-se como a terra: sempre num mesmo sentido. Differe, porém, desta, por uma circumstancia. Ella tem o forte capricho migratório. A civilização brahmane influiu em certa época sobre a hellenica, para mais tarde soffrer a inffluencia desta. Assim, a civilização actual da Europa não periclita: muda-se e muda-se para a América, escolhida para servir-lhe de berço, por alguns dos séculos vindouros. (Idem, p. 26)

Nitidamente otimista, concluí:

Agora, para concluir, fantasiemos: a civilização transferir-se-á depois, como sempre, para outras regiões do orbe, até que, após muito caminhar e muito espalhar as suas sementes por toda parte e, quando estas germinarem e derem fructos a bem há humanidade, mais perfeita, mais homogênea, então, sim, a civilização s estabilizará. Será a época memorável da creação da nova Cahnaan, do novo reino de Abrahão. (Ibidem)

\subsection{Atentados à espécie}

Para além desta noção específica de progresso da qual partilhava e para a qual contribuiu, na construção de seu pensamento Kehl se inspirou também em importantes teorias degeneracionistas, proponentes de uma interpretação historicamente pessimista de algumas sociedades, apontando o decadentismo presente e futuro. De acordo com estas teorias, para muito além dos sistemas sociais e da economia política, as mazelas sociais eram atribuídas às leis da degeneração humana, em oposição ao otimismo que reservava aos helênicos, seus descendentes e conterrâneos continentais. Nota-se que Kehl reservou 
as leis do degeneracionismo aos alvos específicos, enquanto exaltou a prosperidade futura para os dotados das melhores células germinais.

Estas teorias degeneracionistas desenvolvidas, sobretudo, durante o conturbado século XIX ganharam força a ponto de configurar um movimento cuja abrangência deuse da filosofia à antropologia criminal, presentes no contexto intelectual de Kehl e seus interlocutores.

A degeneração como modelo de compreensão - fortemente influenciada pela ideia de decadência das sociedades - é usualmente considerada um movimento de origem francesa, configurado como escola de pensamento que fornecia explicação para aquilo tido como socialmente perturbador - como a superpopulação gerada pela supracitada urbanização típica do século XIX, o estilo de vida dos operários, os protestos políticos, o alcoolismo, a prostituição e outros exemplos daquilo que era considerado subversivo da ordem.

O historiador estadunidense Arthur Herman atenta para uma definição da degeneração como “um desvio mórbido de um modelo inicial”. Partindo da reflexão sobre os trabalhos do médico italiano Cesare Lombroso - cujos estudos correlacionavam comportamentos desviantes e aspectos físicos -, afirma:

Lombroso estava convencido de que havia encontrado a chave para um problema que começava a atormentar outros membros da profissão médica: o medo da "degeneração", a possibilidade de que a população da Europa não fosse mais capaz de suportar as exigências da vida civilizada. (Herman, 1999, p. 120)

Neste caso, a degeneração encontrava raiz comum: maus resíduos atávicos. Semelhante ao pensamento fixista sobre a hereditariedade, os portadores destes resíduos rumavam para a formação de uma nova subspécie. Segundo Herman: 
Médicos, biólogos, zoólogos e antropólogos- os principais membros das novas profissões científicas- foram os primeiros a dar o alarme. Em 1890 havia um consenso crescente de que uma onda de degeneração varria a paisagem da Europa industrial, deixando em seu rastro desordens tais que incluíam o aumento da pobreza, do crime, do alcoolismo, da perversão moral e da violência política... Os cientistas mais preocupados com a degeneração eram, com poucas exceções, fortemente progressistas e até mesmo socialista em suas opiniões políticas. Estavam longes de serem os conservadores defensores do status quo, como costumam ser apresentados por alguns historiadores. Lombroso, por exemplo, era membro do Partido Socialista Italiano e construiu sua carreira combatendo a pobreza e a desnutrição entre os meeiros agrícolas mais pobres, o que fez com que ganhasse a antipatia da aristocracia e dos proprietários rurais. (Idem, p. 121)

O mesmo período inspirou teorias explicativas acerca das diferenças socioeconômicas e, de uma maneira sintética, da origem da pobreza versus riqueza. Questionava-se racionalmente a existência de condições materiais tão diversas e a esta diversidade eram atribuídos elementos cuja essência, portanto, supostamente seria mais profunda do que as leis básicas da economia. Por outro lado, a tradição filosófica britânica, na época marcada pelo laissez-faire do liberalismo econômico proposto por Adam Smith em A Riqueza das Nações (1776), pressupunha a existência de forças de regulação naturais que controlariam a economia em seu conjunto; bem como a teoria econômica de Thomas Malthus, descrita em Ensaios sobre a População (1798) - que Darwin anunciou como uma das obras que mais o influenciou - propunha uma contradição aparentemente insuperável: a população crescia em progressão geométrica, enquanto os alimentos o faziam em progressão aritmética. Diante desta inevitabilidade, as catástrofes (como epidemias e guerras) se incumbiriam de restabelecer o equilíbrio entre a proporção de alimentos e seres humanos no planeta (MAGALHÃES, 2007).

Tendo pressupostos complementares, estas teorias sugeriam a existência de forças maiores - de uma certa maneira, inalcançáveis por medidas socioeconômicas, políticas e culturais - que justificavam estas diferenças. 
Para Kehl, a degeneração individual e consequente decadência coletiva dava-se, sobretudo, por duas razões: reprodução dos portadores de células germinais de características indesejadas e reprodução daqueles submetidos aos fatores disgênicos adquiridos e repassados, como o alcoolismo ou a sífilis. Tais convicções demonstram que Kehl, ao aceitar a teoria de Weismann sobre a resistência das células germinais, não deixava de considerar - e sobre isto a controvérsia era, e ainda o é, intensa- o pressuposto da influência do meio nos caracteres transmissíveis. A lei da decadência deduzia-se, assim, em contraposição à lei do progresso. E, assim como a criação daquilo que considerava como mecanismos artificiais de existência eram impeditivos do progresso, permitir a reprodução destes seres disgênicos eram sua garantia.

Dentre os fatores disgênicos, é certo que os portadores de doenças diversas ou condições especiais - ou aqueles suscetíveis a elas- foram o grande alvo de preocupação dos eugenistas. Muitas eram as condições atribuídas a hereditariedade e, para além dos quesitos de raça, cor, etnia ou status social, a estigmatização negativa dos doentes era unanimidade entre eugenistas de convicções diversas. Para estes sobre os quais o estigma recaía, a esterilização era método recomendado sem grande oposição, considerado um altruísmo em prol da coletividade.

No entanto, Kehl e muitos de seus colegas de convicções mais radicais estendiam suas preocupações degeneracionistas para outra questão: a miscigenação. Esta seria uma possibilidade da natureza que perverteria a preservação das boas células germinais, contaminando-as e, assim, revertendo a lei do progresso para a lei da decadência pelo "hibridismo". Assim, a questão da mestiçagem e, consequentemente, da imigração, tornaram-se alvo de sua militância.

A fim de justificar seu posicionamento contra a miscigenação, Kehl apresenta, na 
mesma obra, tabelas comprovando que há um "valor étnico" definidor das qualidades e defeitos dos indivíduos e, pela lei da preservação dos caracteres, definidor da sociedade de origem. O método estatístico se dava de maneira simples, pela análise das condições sociais e tipos médios de estados que receberam elementos étnicos inferiores ou superiores. Nota-se que as noções de superioridade ou inferioridade eram postulados inquestionáveis:

Os Estados com coefficientes mais altos de typos superiores são, justamente, os que devem sua origem ao núcleo primitivo dos Pilgrim Fathers, isto é, daquelles homens de caracter superior que, fugindo ás perseguições religiosas, trocaram a pátria pelas selvas do Novo Mundo. Por outro lado, pondera Oliveira Vianna, os Estados em que o índice eugênico é mais baixo, são justamente aquelles, como o Novo Mexico, em cuja ethnogenese intervieram elementos ethnicos inferiores ou bárbaros. (KEHL, 1929, p. 185)

No caso brasileiro, dada a intensa imigração e a presença histórica das "raças negras e selvícolas", o problema da miscigenação tornava-se o grande empecilho contra as leis do progresso, afirmando mesmo que a questão do valor étnico aqui estaria para além das preocupações com a saúde:

\begin{abstract}
O problema da immigração é de grande importância eugenica. Merece ser tido em alta conta pelo nossos dirigentes. Precisamos de leis severas que estipulem as condições para a entrada de alienígenas no paiz. Não basta a simples verificação do estado de saúde e da aptidão para o trabalho. Faz-se mister considerar o valor ethnico. Há povos que nos conve, e outros que devemos evitar. O nosso representa verdadeira salada de raças incompatíveis. A nacionalidade está em estado de cólicas: o metabolismo processa-se, irregularmente,; os órgãos emunctórios não apresentam capacidade para a desassimilação; cada dia são absorvidos novos elementos inconciliáveis. (Idem, 1929, p. 187)
\end{abstract}

Haveria, portanto, de se evitar a reprodução de células germinais que, por incompatibilidade biológica com aquelas dos descendentes europeus, acabariam por nos levar à decadência. Assim como alguns povos estavam fadados ao progresso, outros 
estariam naturalmente fadados à desassimilação e, por fim, ao desaparecimento:

O Brasil representa uma "officina gentium", um grande laboratório de elementos diversos, e dentro delle terá de se operar por muito tempo um grande metabolismo racial, com a assimilação de uns e a desassimilação de outros. Dessa chimica complexa e morosa resultará, daqui a alguns séculos, apezar dos prejuízos acarretados á raça branca, uma nacionalidade melhormente caracterizada, um povo forte e varonil que, talvez, se emparelhará dignamente, com os melhores aquinhoados. Dentre os elementos em desassimilação, como dissemos, contam-se os da raça negra e selvícola. Há uma verdadeira depuração desses sangues. Ninguém poderá negar, que no correr dos annos, desapparecerão os negros e os índios das nossas plagas e do mesmo modo os produtos provenientes desta mestiçagem. A nacionalidade embranquecerá á custa de muito sabão de côco aryano! (KEHL, 1929, p. 188)

\title{
4.3 Filantropia subversiva
}

Kehl deixava evidente a necessidade, por parte dos dotados de razão, de racionalmente tomarem partido na condução intelectual e política do país - iluminando os que se deixavam levar pelas emoções humanas com a nova ciência do progresso humano. Em seu Dicionário filosófico, ao discorrer sobre o verbete "progresso", Kehl forneceu mais elementos que elucidam seu posicionamento no complexo contexto de definição do papel das ciências biomédicas no Brasil:

\begin{abstract}
A humanidade ama os sonhos e deixa-se governar pelos que sabem alimentálos. Basta um homem para atrasar uma coletividade, como basta um outro para levá-la aos mais belos destinos. Não fosse a morte e os povos se estagnariam sob o guante dos conservadores. Para que o carro do progresso continue na marcha ascensional é mister que surjam sempre novos mentores. (KEHL, 1938 p. 155)
\end{abstract}

Progredir também era, portanto, abdicar das emoções próprias e deixar conduzir-se pelos sonhos de outrem.

O periódico Boletim de Eugenia, publicado entre os anos de 1929 a 1933 constituiu 
um profícuo espaço de reunião e discussão desses mentores que, ocupando posições de lideranças nas ciências, na educação e na política, puseram-se a discutir, para além das teorias, as possibilidades de implantação das práticas eugenizantes no Brasil.

Tendo Kehl como idealizador, mentor e patrocinador, os principais projetos discutidos nos boletins clamavam, sempre com embasamento científico, pela criação de uma legislação eugênica que garantisse o progresso biológico do país. Tais projetos consistiam na parte prática da eugenia, ou social e, em síntese, propunham, segundo a lógica das leis expostas, barrar a decadência por meio de esterilizações, restrições imigratórias e matrimoniais, segregação dos doentes e criminosos e, em contrapartida, fomentar o progresso pelo estímulo e apoio ao desenvolvimento dos portadores de células germinais detentoras de virtudes. Para que tais projetos vingassem, era crucial que os degenerados não recebessem auxílios anti-naturais.

O tema do progresso eugênico foi perene e orientou todas as suas produções significativas, que iam das cartilhas infantis com propostas de educação moral difundidas entre as escolas públicas na década de 50 - passando pelos manuais práticos sobre como escolher um bom marido ou esposa - cuja vendagem atingiu o ápice na década de 20 - , ao livro Catecismo para Adultos, publicado em 1942.

A singular proposta de catequese elaborada por Kehl é justificada em epígrafe própria: a eugenia seria, afirma,

o pedestal da religião que tem por escopo a regeneração integral da humanidade. Não visa perseguir fracos, doentes nem degenerados. Ao contrário: ela que evitar o aparecimento desses infelizes que nascem pra morrer, para sofrer e para sobrecarregar a parte produtiva da coletividade. Constitue a verdadeira ciência da felicidade, porque se esforça pela elevação moral e física do homem, a fim de dotá-lo de qualidades ótimas, de fornecerlhes elementos de paz na família e na sociedade. (KEHL, 1942, p. 15) 
O texto prossegue em forma de perguntas e respostas, em tentativa de antecipar aqueles que poderiam ser os principais anseios e dúvidas dos leitores perante aquilo que, já no início, indica como sendo a "ciência-arte de Galton”. Dentre a vasta argumentação construída, as respostas tornaram-se imediatamente propostas que anunciavam uma importante singularidade: os novos sentidos do progresso estariam justamente na contra mão dos caminhos propostos pela solidariedade, até então uma qualidade, mas que consistiria em sentimento duvidoso, falso orientador para o caminho da elevação. 


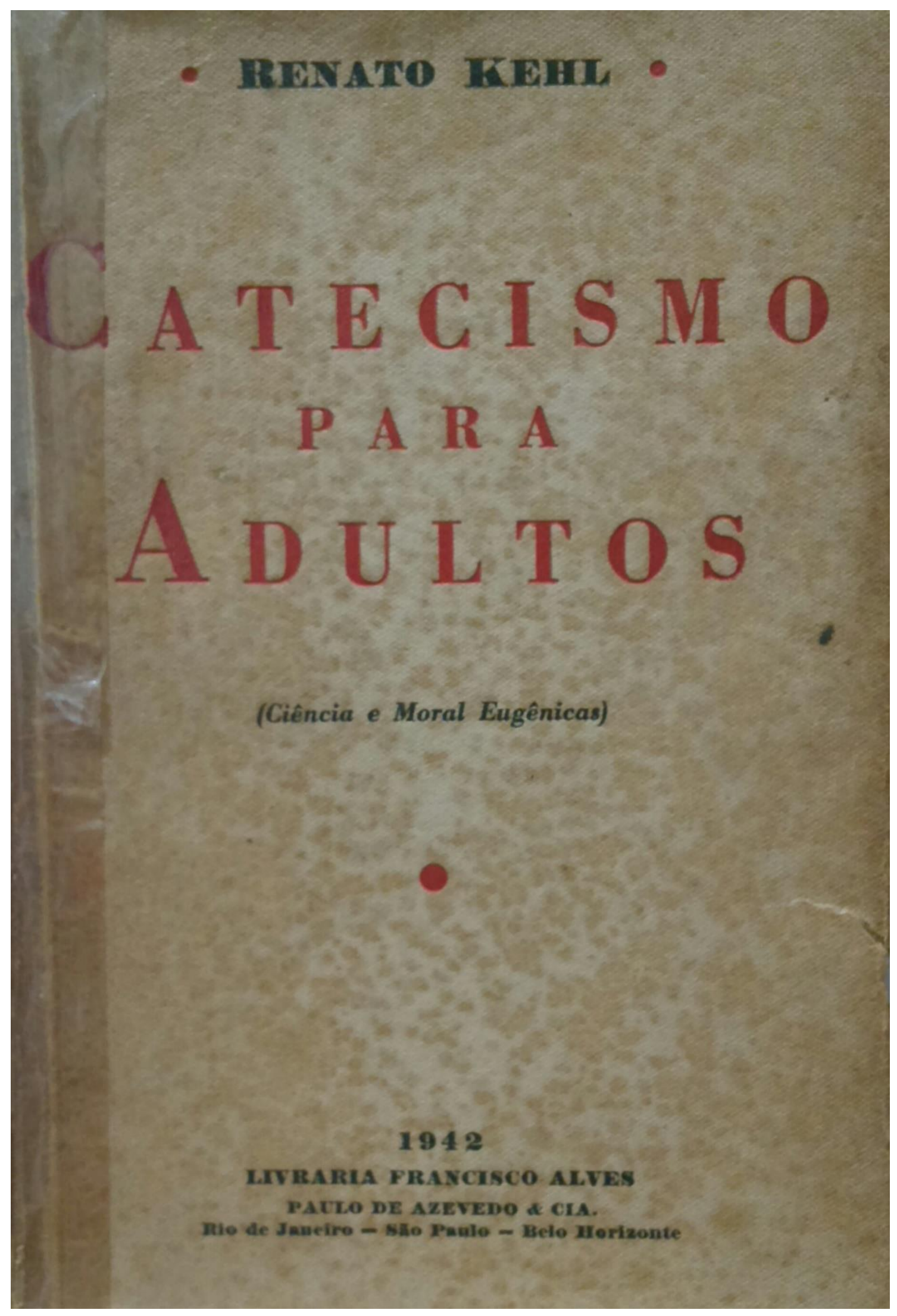

Figura 15. Reprodução da capa da obra Catecismo para adultos (1942) 


\section{Rio de Janeiro, 3 de Janeiro de 1942}

Ao Sr. Dr. Renato Kehl.
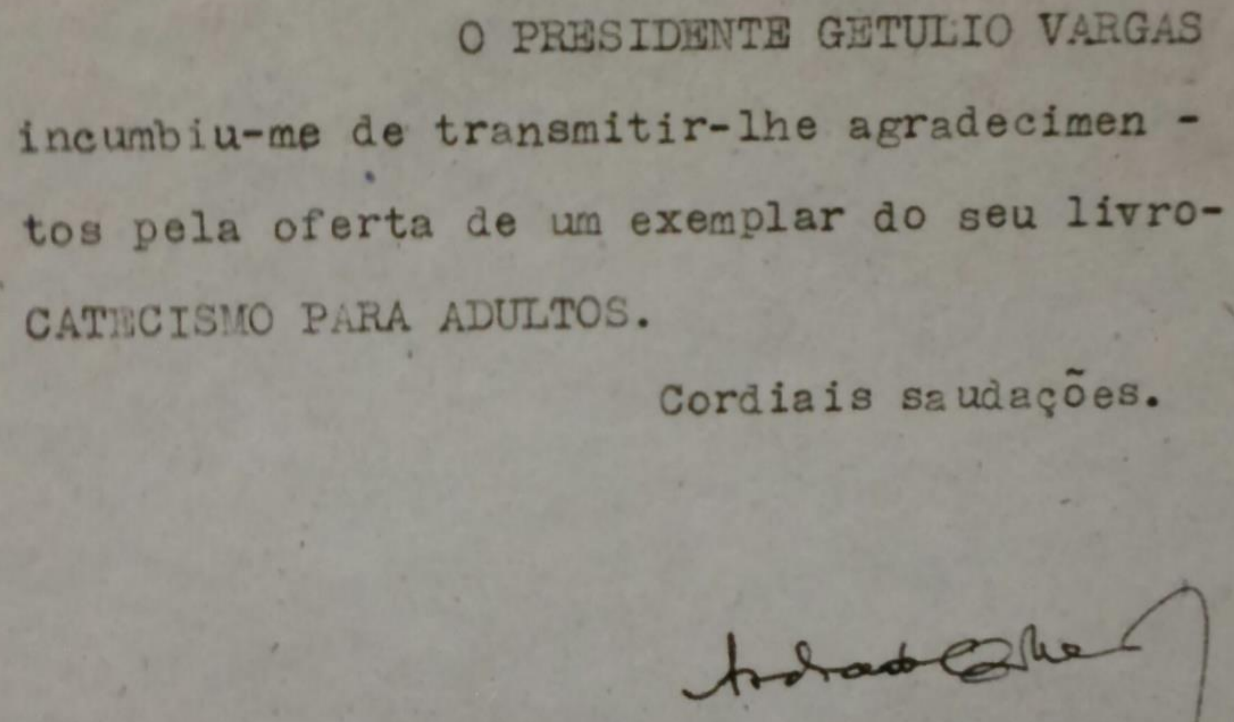

Oficial de Gabinete

Figura 16. Nota de agradecimento enviada em nome do presidente Getúlio Vargas pelo recebimento da obra Catecismo para adultos. Acervo do Departamento de Arquivo e Documentação Casa de Oswaldo Cruz- FIOCRUZ. Fundo Renato Kehl.

Ao questionar: "Quais as mais graves transgressões cometidas pelos homens contra a própria espécie?", elabora a resposta com aquelas que considera mais nocivas: as guerras, que provocariam a eliminação de superiores e preservação de inferiores (doentes e 
incapazes); a filantropia contra-seletiva e a filantropia médica, que favoreceriam aqueles que, se vivessem por si, deveriam desaparecer; o sentimentalismo, que age a favor dos fracos e, por fim, o urbanismo e a higiene, que conferiria aos incapazes armas artificiais para reagir contra as armas letais do meio ambiente.

Concebe-se, assim, o assistencialismo como instrumento contra o progresso. Noção que carrega em seu cerne, sob a égide do suposto status científico -portanto, mais certeiro e superior- a condenação dos traços humanos que melhor concorreram para a formação das civilizações. A solidariedade tornava-se, assim, sob a perspectiva do progresso eugênico, grande transgressora e subversiva da ordem natural, onde os mais fortes deveriam prevalecer. Mesmo que esta lógica ignorasse que o prevalecimento se fazia às custas daqueles que consideravam mais fracos, tais quais os gregos que se sustentavam pelo regime escravista.

Em trecho elucidativo, Kehl em seu dicionário define o verbete "seleção negativa" com um jogral:

\footnotetext{
- Por que tantos maus a espalharem o desassossego, a dor, a desordem, a morte? Por que tanta calúnia, vilania, traição, crueldade?

- Porque a maldade, a despeito dos esforços religiosos, educativos e punitivos, se sobrepõe à piedade, ao altruísmo.

- E por que essa sobreposição anti-natural, anti-social e anti-humana?

- Por culpa do artificialismo reinante nos agrupamentos humanos. Como todos têm o mesmo direito à vida, os fracos, os débeis mentais, os degenerados, vivem, procriam, multiplicam-se sob a proteção de favores que, muitas vezes, são negados aos fortes, aos inteligentes- em suma, aos verdadeiros esteios da perpetuação melhorada da espécie. (KEHL, 193, p. 158)
}

Sem interferências em prol dos considerados mais fracos - apenas dos mais fortes, merecedores de incentivos - era preciso, portanto, permitir que as "leis naturais" 
devidamente decifradas pelas ciências biológicas se realizassem plenamente, tal como ocorria com as ervilhas autofecundadas de Mendel, com as amebas unicelulares ou com os micróbios:

O valor da mediocridade está no grande número de seus componentes. Tais os artifícios existentes para a sua defesa, que se tem a impressão de falência da seleção natural. Esta falência, entretanto, jamais se dará porque a seleção atua imperceptível, muitas vezes, mas permanentemente. Observa-se, apenas, o adiamento de seu efeito. Com o correr do tempo o artificialismo protelador cede lugar ao naturalismo selecionador. A massa cresce como se dá com as colônias de micróbios dos laboratórios, mas, de tanto crescer, acaba por ser auto-exterminar. (Idem, p. 159)

Caberia a humanidade, porém, transpor o obstáculo do sentimentalismo em prol do racionalismo naturalista que - tal como ocorria com as ervilhas - garantisse a uniformidade de nossas gerações descendentes. Em conclusão elucidativa do pensamento de seu tempo e também de debates do tempo presente, afirma:

\begin{abstract}
Os corações bem formados são, por natureza, suscetíveis aos sofrimentos alheios. Penaliza-nos a situação difícil de certos indivíduos, confrangendo-nos, sobretudo, o estado miserável de certas crianças, cujos pais não têm meios para agasalhá-las, vestí-las, alimentá-las ou educá-las. O sofrimento desses indivíduos, entretanto, é muito relativo: sofremos talvez mais por eles do que eles próprios... Se houvesse um aparelho para registrar e medir exatamente as variações da sensibilidade ou a grandeza de um sentimento, nós nos certificaríamos de que absolutamente não vale a pena nos mortificarmos com as misérias alheias. Impõe-se aos corações bem formados o dever de auxiliar os que precisam de nossos socorros, sem, contudo, nos condoermos exageradamente com a pouca sorte de tanta gente. (Ibidem, p. 160)
\end{abstract}

Anos mais tarde, ao retornar à cidade natal de Limeira para proferir uma palestra em comemoração ao Dia da Raça (12/10/1940), Renato faz uma reflexão acerca dos passados anos da campanha brasileira, bem como aponta previsões futuras. Afirma que seus livros provavelmente seriam considerados clássicos, dado que representaram importante papel na revolução das ideias nacionais, despertando, afinal, o interesse dos intelectuais brasileiros para a preocupação eugenista. Naquele momento esta seria a 
preocupação máxima de todos os povos, finalmente trazida aos intelectuais que até então teriam estado entregues a "romantismos" e "novelismos".

Compartilhou nesta mesma palestra quais teriam sido as motivações que o levaram ao empenho incansável com que assumiu e disseminou as convicções eugenistas, elucidando, assim, suas principais premissas, esclarecendo os objetivos e, em última instância, expressando uma perspectiva específica - tão individual quanto coletivaacerca das diferenças humanas:

\begin{abstract}
Desde muito jovem dois fatos me impressionaram, dando margem a cogitações que nunca mais me abandonaram e que contribuíram, fundamentalmente, para a minha inclinação pela eugenia. Um refere-se à espantosa profusão de degenerados; outro à grande dissemelhança morfológica existente entre os homens, ao contrário do que se observa, correntemente, com os animais da mesma raça e criação... De tal maneira se espalham essas anomalias físicas e psíquicas que bem poucos são os que merecem o qualificativo de eumórficos, isto é, de integralmente perfeitos de corpo e de espírito. (Kehl, 1940, p. 33, palestra)
\end{abstract}

Pressupondo a existência dos eumórficos e da perfectibilidade criou-se, assim, dicotomias que persistiram ao longo do tempo e corroboraram políticas de combate quetal qual defendia explicitamente Kehl- por vezes não tiveram como alvo as mazelas situacionais, mas sim os seres em si:

De tal modo e por força do determinismo, que criou o hábito, a grande maioria dos homens já considera os desvios da norma como fatalidade irremediável, não dando conta do que representam como atentados à espécie. Graças a esta acomodação do senso estético, passam despercebidos... quase a totalidade dos homens, as desordens chocantes da plástica e as da esfera psíquica. Assim, pois, o espetáculo das deformidades e, como disse, também a estranha diversidade de tipos humanos, que me levaram a estudar os problemas biológicos da hereditariedade e dos da influência do meio sobre a espécie humana. (Idem) 


\section{Referências}

\section{Fontes primárias:}

GALTON, F. Inquiries into Human Faculty and its development. Londres: Macmillan, 1883. Primeira edição eletrônica, 2001.

eletrônica, 2000.

Hereditary Genius. Londres: Macmillan \& Co, 1869. Primeira versão

KEHL R. Bio-Perspectivas: Dicionário Filosófico. São Paulo: Livraria Francisco Alves, 1938.

. A Interpretação do Homem. Rio de Janeiro: Livraria Francisco Alves, 1951.

Lições de Eugenia. Rio de Janeiro: Livraria Alves, 1929.

. Por que sou Eugenista. Rio de Janeiro: Livraria Francisco Alves, 1937.

Editores, 1923.

. A cura da fealdade: eugenia e medicina social. São Paulo: Monteiro Lobato

- A eugenia prática. Reimpressão d'A Folha Médica de 15 de fevereiro de 1929. Rio de Janeiro: Canton \& Beyer, 1929, p. 3.

Educação Eugênica. Exemplar 1. Rio de Janeiro: Livraria Francisco Alves, 1932.

Catecismo para adultos. Rio de Janeiro: Livraria Francisco Alves, 1942.

Alves, 1923.

Eugenia e Medicina Social: problemas da vida. Rio de Janeiro: Francisco

. A Cura do Espírito. Rio de Janeiro: Livraria Francisco Alves, 1947.

jun-jul. 1929

O Instituto de Eugenia. Boletim de Eugenia. Rio de Janeiro, vol. I, nº 6-7,

. A Eugenia na Europa e no Brasil (entrevista com o eugenista Renato Kehl). O Jornal. Rio de Janeiro, 18set. 1928, (Recorte avulso, Fundo Pessoal Renato Kehl).

Pessoal Renato Kehl).

. "O Médico da coletividade". [palestra] 1940. (Recorte avulso, Fundo

Correspondências de Renato Kehl. São Paulo, s/d (Fundo Pessoal Renato Kehl).

Actas de Trabalho. Primeiro Congresso Brasileiro de Eugenia. Vol.1. Rio de Janeiro, 1931.

Annaes de Eugenia. São Paulo, 1919.

Boletim de Eugenia. Rio de Janeiro (1929-1942) 


\section{Bibliografia geral:}

ADORNO, T. W. (2003). "Educação após Auschwitz". In: Educação e Emancipação. 3 3 a Ed. São Paulo: Paz e Terra.

AROUCA, S. O dilema preventivista: contribuição para a compreensão e crítica da medicina preventiva. São Paulo: Editora UNESP; Rio de Janeiro: Editora FIOCRUZ, 2003.

BARBOSA, W. N. O problema da metodologia na prática da pesquisa social. Palestra em 30.04.1992. Programa de Pós-Graduação. Departamento de História. FFLCH-USP.

BENJAMIN, W. Sobre o conceito de história. In: Magia e técnica, arte e política: ensaios sobre literatura e história da cultura. São Paulo: Brasiliense, 1994

BLACK, E. A guerra contra os fracos: a eugenia e a campanha norte-americana para criar uma raça superior. São Paulo: A Girafa, 2003.

BLANC, Marcel. Os Herdeiros de Darwin. São Paulo: Scritta, 1994.

BOARINI, Maria L. (org.). Higiene e raça como projetos: higienismo e eugenismo no Brasil. Maringá: Eduem, 2003.

CANGUILHEM, G. O Normal e o Patológico. $5^{\mathbf{o}}$ Ed. Rio de Janeiro: Forense Universitária, 2002.

CASTRO, E. Vocabulário de Foucault - Um percurso pelos seus temas, conceitos e autores. Belo Horizonte: Autêntica Editora, 2009.

CORREA, M. Eugenia no calor da hora. História, Ciências, Saúde - Manguinhos. Vol. 13. $N^{\circ}$ 2. Rio de Janeiro, apr-jun, 2006.

CRUZ, R. A. "Das ervilhas mendelianas ao 'décimo submerso'. Aspectos teóricos e práticos do desenvolvimento da eugenia nos Estados Unidos." In: MOTA, André. MARINHO, Maria Gabriela S. M. C. Eugenia e História: Ciência, Educação e Regionalidades. São Paulo: USP, Faculdade de Medicina; UFABC, Universidade Federal do ABC. Casa de Soluções Editora, 2013.

DARWIN, C. A origem das espécies e a seleção natural. Curitiba: Hemus, 2000.

DEL CONT, V. "Francis Galton: eugenia e hereditariedade. In: Scientiae Studia, vol. 6, n², São Paulo abril-junho de 2008.

DINIZ, D.; GUILHEM, D. O que é Bioética? São Paulo: Brasiliense, 2005.

DIWAN, P. O espetáculo do feio: práticas discursivas e redes de poder no eugenismo de Renato Kehl. São Paulo, 2003. Dissertação de Mestrado- PUC/SP. 
Contexto, 2007.

Raça Pura: uma história da eugenia no Brasil e no mundo. São Paulo:

DOSSE, F. O Desafio Biográfico: escrever uma vida. São Paulo: Edusp, 2009.

FAUSTO, B. História do Brasil. São Paulo: Editora da Universidade de São Paulo, 2003.

FERLA, L. A. C. Feios, Sujos e Malvados Sob Medida: do crime ao trabalho, a utopia médica no biodeterminismo em São Paulo 1920-1945. São Paulo, Tese de Doutorado, Depto. de História, FFLCH-USP, 2005.

FOUCAULT, M. Microfísica do Poder. Rio de Janeiro: Graal, 1979.

A Ordem do Discurso. São Paulo: Edições Loyola, 1996.

História da Sexualidade I: A vontade de saber. Rio de Janeiro: Edições Graal, 1988.

GOLISZEK, A. Cobaias humanas: a história do sofrimento causado em nome da ciência. São Paulo: Ediouro, 2004.

GINZBURG, C. Mitos, emblemas, sinais: morfologia e história. São Paulo: Companhia das Letas, 1989.

GOULD, S. J. A Falsa Medida do Homem. 2a ed. São Paulo: Martins Fontes, 1999.

GUALTIERI, R. C. E. O evolucionismo na produção científica do Museu Nacional do Rio de Janeiro (1876-1915). In: Heloísa Maria Bertol Domingues; Magali Romero; Thomas Glick. (Org.). A recepção do darwinismo no Brasil - Coleção História e Saúde. Rio de Janeiro: Editora Fiocruz, 2003.

HABERMAS, J. O futuro da natureza humana. $2^{\text {a }}$ Ed. São Paulo: Editora WMF Martins Fontes, 2001.

HERMAN, A. A ideia de decadência da História Ocidental. Rio de Janeiro: Record, 1999.

HOSBAWN, E. J. Nações e Nacionalismo desde 1870: programa, mito e realidade. São Paulo: Paz e Terra, 2013.

. Da Revolução Industrial Inglesa ao Imperialismo. Rio de Janeiro:

Forense, 2013.

.A era dos extremos: o breve século XX. São Paulo: Companhia das Letras,

1995.

JACOB, F. A Lógica da Vida. Rio de Janeiro: Edições Graal, 1983.

KEVLES, D. J. In the name of eugenics. Genetics and the Uses of Human Heredity. Harvard University Press. Cambridge, Massachusetts, 1995.

KINOSHITA, C. T. Um D. Quixote científico a pregar para uma legião de panças: 
Manuais escolares de higiene à sombra da Eugenia (1923-1936). Dissertação de mestrado, Faculdade de Educação. Universidade Estadual de Campinas. 2013

LATOUR, B. Joliot: a história e a física misturadas. in Elementos para uma História das Ciências. SERRES, Michel (Ed). Lisboa: Terramar, 1996.

MAGALHÃES, G. A evolução das Espécies: da Natureza ao liberalismo econômico. Revista de História Comparada, v. 2, p. 205-307, 2007.

MAIO, M. C., VENTURA, R. (orgs.). Raça, Ciência e Sociedade. Rio de Janeiro: Centro Cultural do Banco do Brasil/Editora Fiocruz, 1996.

MARQUES, V. R. B. A medicalização da raça: médicos, educadores e discurso eugênico. Campinas: Editora da Unicamp, 1994.

MOTA, A. O que é bom já nasce feito: sanitarismo e eugenia no Brasil. Rio de Janeiro: DP\&A, 2003.

Tropeços da Medicina Bandeirante: medicina paulista entre 1892- 1920.

São Paulo: Edusp, 2005.

MOSLEY, M. LYNCH, J. Uma história da ciência: experiência, poder e paixão. Rio de Janeiro: Zahar, 2011.

SANTOS, R. A. "Lobato, os jecas e a questão racial no pensamento social brasileiro". In: Achegas.net, $n^{\circ} 7$, maio de 2003.

SCHRAIBER, L. B. O médico e seu trabalho: limites da liberdade. São Paulo: Hucitec, 1993.

SCHWARCZ, L. M. (org.). O espetáculo das raças: cientistas, instituições e questão racial no Brasil do século XIX. São Paulo: Companhia das Letras, 1993.

SKIDMORE, T. Preto no Branco: raça e nacionalidade no pensamento brasileiro. Rio de Janeiro: Paz e Terra, 1989.

SMITH, A. Nacionalismo. Lisboa: Editorial Teorema, 2001.

SOUZA, V. A política biológica como projeto: a "eugenia negativa" e a construção da nacionalidade na trajetória de Renato Kehl (1917- 1932). Rio de Janeiro, 2006. Dissertação de Mestrado em História das Ciências- Fundação Casa de Oswaldo Cruz/ Fiocruz.

. Em busca do Brasil: Edgard Roquette-Pinto e o retrato antropológico brasileiro. Tese (Doutorado em História), Casa de Oswaldo Cruz, Fundação Oswaldo Cruz, Rio de Janeiro, 2011.

STEPAN, N. The hour of eugenics: race, gender and nation in Latin America.. London: Cornell University Press, 1991.

VEYNE, P. Como se escreve a História? Brasília: Editora Universidade de Brasília, 1998. 
XIBERRAS, M. As teorias da exclusão: para uma construção do imaginário do desvio. Lisboa: 1993, Instituto Piaget.

\section{Documentário:}

COHEN, P. Homo Sapiens 1900. Filme DVD. Produção: Peter Cohen. First Run Features, 2004. 85 minutos. 